UNIVERSIDADE DE SÃO PAULO - USP ESCOLA DE ENGENHARIA DE SÃO CARLOS

PROGRAMA DE PÓS GRADUAÇÃO EM ENGENHARIA HIDRÁULICA E SANEAMENTO - PPG-SHS

CÁSSIO LUIZ IANNI ZAPATERRA

ESTUDO DA MELHORIA DO DESEMPENHO DE SISTEMAS DE RESFRIAMENTO EVAPORATIVO POR MICRO ASPERSÃO DE ÁGUA

VERSÃO CORRIGIDA

SÃO CARLOS - SP 


\author{
UNIVERSIDADE DE SÃO PAULO - USP \\ ESCOLA DE ENGENHARIA DE SÃO CARLOS \\ PROGRAMA DE PÓS GRADUAÇÃO EM ENGENHARIA HIDRÁULICA E \\ SANEAMENTO - PPG-SHS
}

\author{
CÁSSIO LUIZ IANNI ZAPATERRA
}

\title{
ESTUDO DA MELHORIA DO DESEMPENHO DE SISTEMAS DE RESFRIAMENTO EVAPORATIVO POR MICRO ASPERSÃO DE ÁGUA
}

\begin{abstract}
Dissertação apresentada à Escola de Engenharia de São Carlos da Universidade de São Paulo, como parte dos requisitos para obtenção do título de Mestre em Ciências: Engenharia Hidráulica e Saneamento.

Orientador: Prof. Tit. Marcius Fantozzi Giorgetti
\end{abstract}

VERSÃO CORRIGIDA

SÃO CARLOS - SP

2016 
AUTORIZO A REPRODUCÃO TOTAL OU PARCIAL RESTE TRABALHO. POR QUALQUER MEIO CONVENCIONAL OU ELETRONICO, PARA FINS DE ESTUDO E PESQUISA, DESDE QUE CITADA A FONTE.

Zapaterra, Cassio Lui = Ianni
ESTUDO DE YEIHORIA DO DESE

ESTUDO DE NELHORIA DO DESENPEMO DE STSTEMaS DE RESFRTALEMTO EVAPORATTVO POR YICROASPERSAO DE AGUA / Cassio Iuiz Ianni Zapaterra: orientador Marcius Fantozai Giorgetti. Sao Carlos, 2016.

Dissertaçlo (Nestrado) - Programa de Pos-Graduaçlo en Engenharia Hidraulica e Saneamento e Area de Concentraça en Hidraulica e Saneamento -- Escola de Engenharia de SLo Carlos da Universidade de SIo Paulo, 2016.

1. Atomizaç2o. 2. Climatiraç:o. 3. Conforto

Termico. 4. KicroaspersLo. 5. Resfriamento Adiabitico. 6. Resfriamento Evaporativo. 7. Trangfertncia de Calor e Kassa. I. Titulo. 
FOLHA DE JULGAMENTO

Candidato: Engenheiro CÁSSIO LUIZ IANNI ZAPATERRA.

Título da dissertaçāo: Estudo da melhoria do desempenho de sistemas de resiriamento evaporativo por micro aspersão de água".

Data da defesa: 29/09/2016.

Comissäo Julgadora:

Prof. Titular Marcius Fanlozzi Giorgetti (Orientador)

(Escola de Engenharia de Såo Carlos/EESC)

Prof. Dr. João Sérgio Cordeiro

(Universidade Federal de Sầo Carlos/UFSCar)

Prol. Dr. Josmar Davilson Pagliuso

(Escola de Engenharia de Sčo Carlos/EESC)
Resultado:

A P no ${ }^{*} D 0$

Aprove do

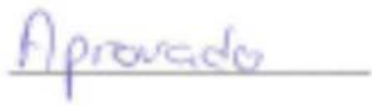

Coordenadora do Programa de Pós-Graduaçōo em Engenharia Hidróulica e Saneamento:

Profa. Associada Maria Bemadete A. Varesche Silva

Presidente da Comissão de Pós-Graduação:

Prof. Associado Luis Fernando Costa Alberto 
Dedico essa dissertação à minha esposa Amira e ao meu filho Raphael, que são a razão da minha devoção, da minha força e persistência. 


\section{AGRADECIMENTOS}

A Deus e à Espiritualidade Maior pela disposição, discernimento e entendimento para realização deste trabalho;

Ao PPG-SHS por ter me aceito, pela possibilidade de executar esse estudo junto ao departamento e, em especial, à Maria Auxiliadora de Campos Altieri Pin - Sá e Priscila Carla Toselli de Almeida, pela ajuda essencial nos procedimentos que conduziram essa dissertação;

Ao Prof. Marcius Fantozzi Giorgetti pela oportunidade, confiança e orientação para que eu pudesse realizar esse estudo;

Ao Prof. Eduardo Cleto Pires pela disponibilidade, dedicação, sugestões e ajuda na condução do trabalho;

Ao Conselho Nacional de Pesquisa - CNPq pela bolsa de estudo concedida;

A todos os funcionários do SHS e a todos meus colegas de pós-graduação, que se tornaram amigos, pelo carinho, apoio e incentivo.

A vocês, meu muito obrigado. 
1. INTRODUÇÃO

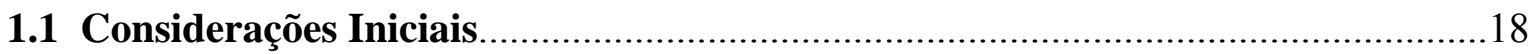

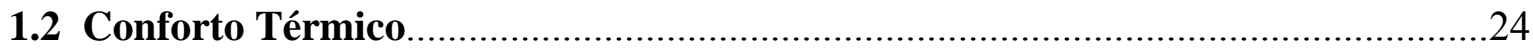

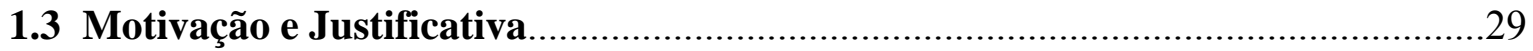

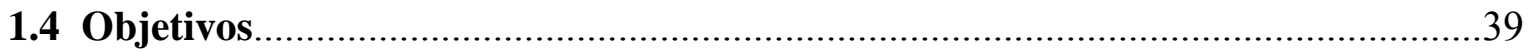

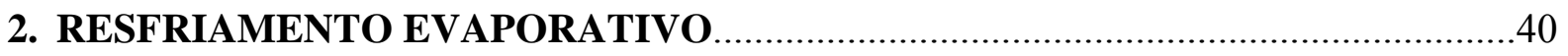

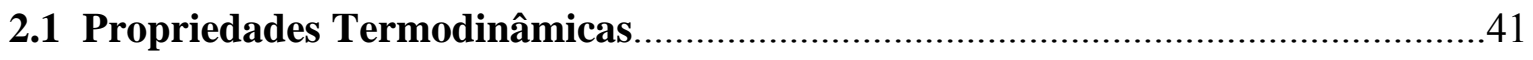

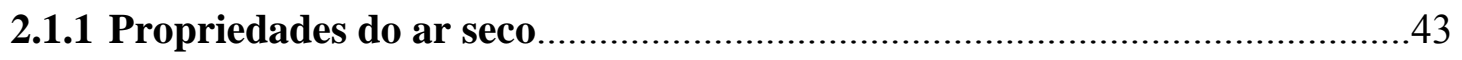

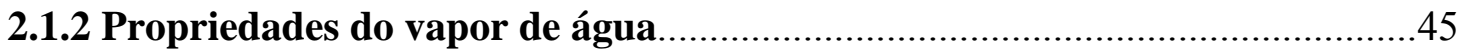

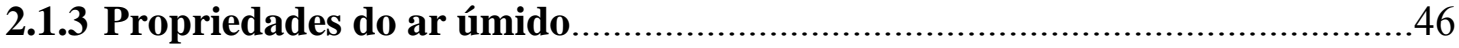

2.2 Propriedades Psicrométricas Relevantes no Processo de Resfriamento

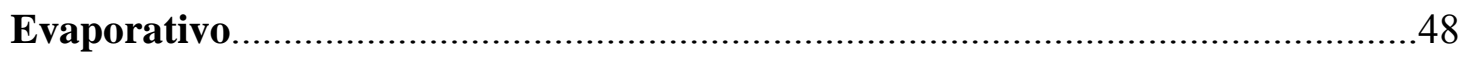

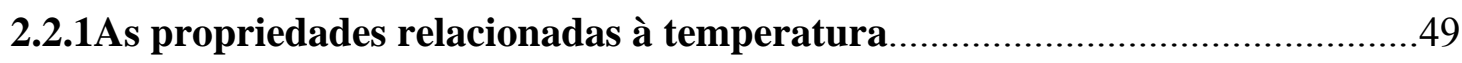

2.2.2 Propriedades relacionadas à umidade.....................................................50

2.2.3 Propriedades relacionadas ao volume ocupado e energia............................52

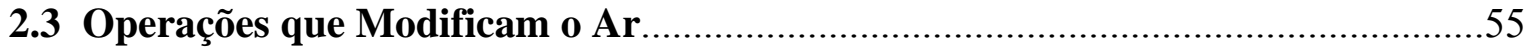

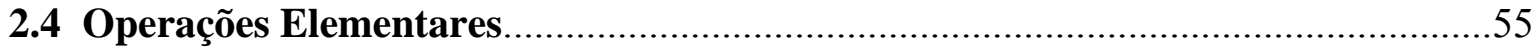

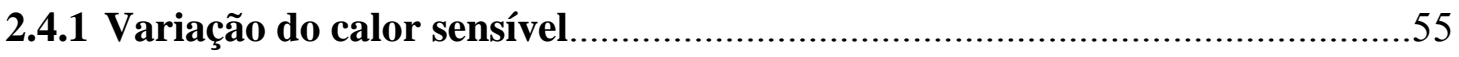

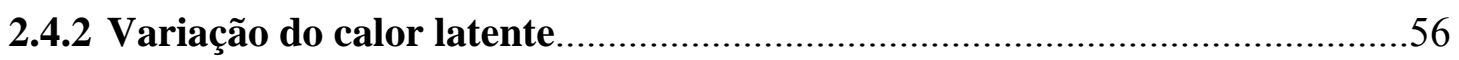

2.4.3 Variações simultâneas de calor sensível e calor latente.................................56

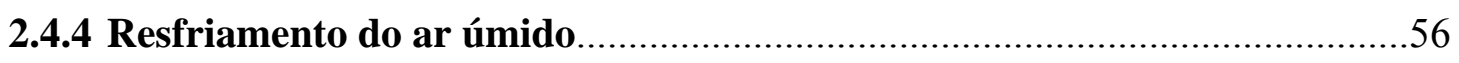

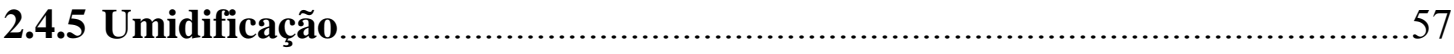

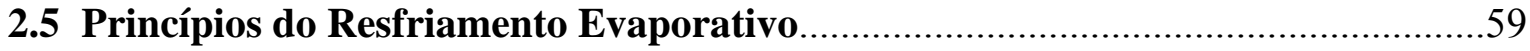

3. CONFORTO TÉRMICO E ECONOMIA ENERGÉTICA ......................................63

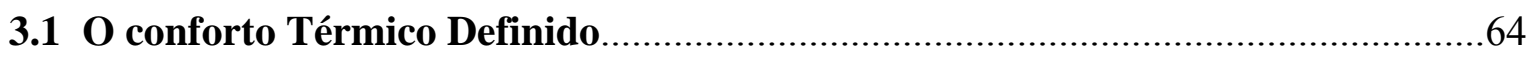

3.2 Condições de Conforto Térmico e Consumo de Energia.........................................68 


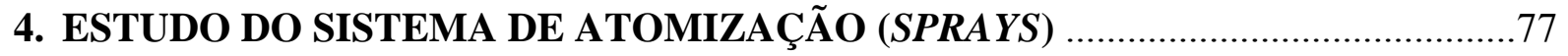

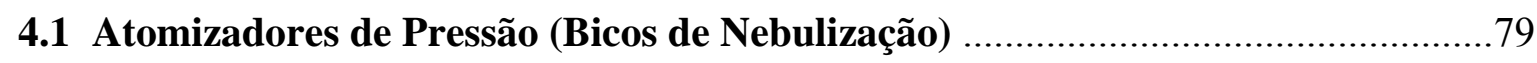

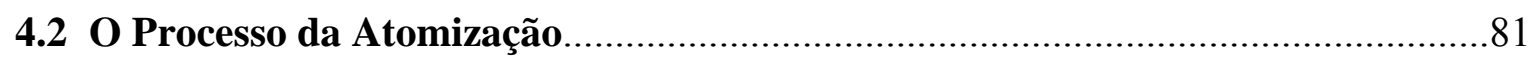

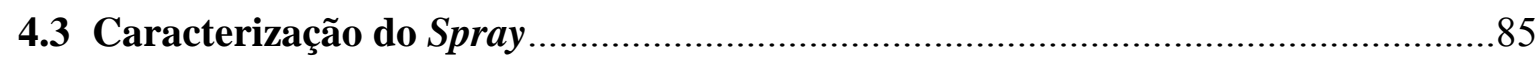

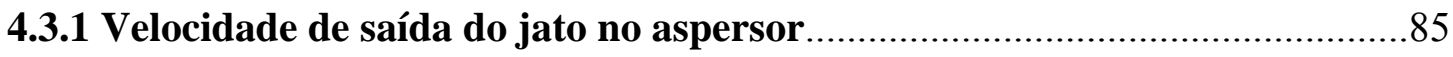

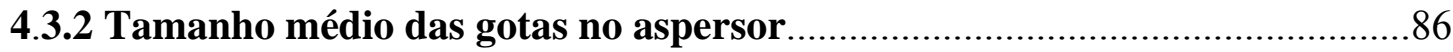

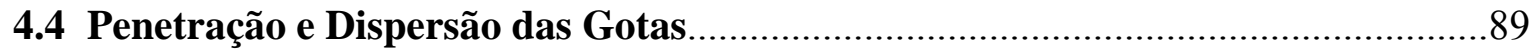

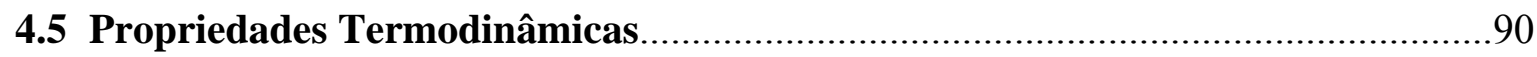

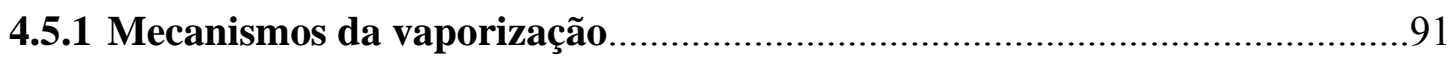

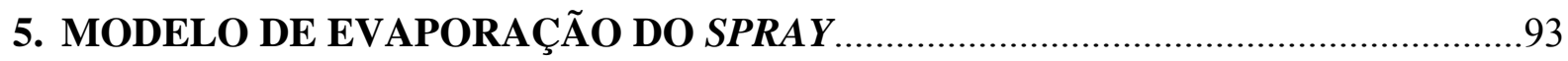

5.1 Modelos Empregados nos Estudos dos Sprays...................................................94

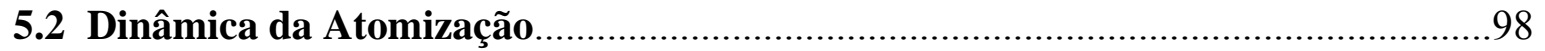

5.3 Propriedades de Transferência de Calor e Massa.....................................................104

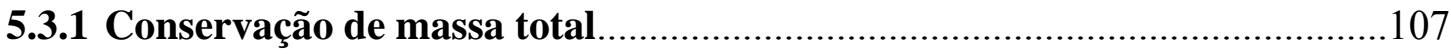

5.3.2 Conservação de cada espécie (água e ar ambiente) …...............................108

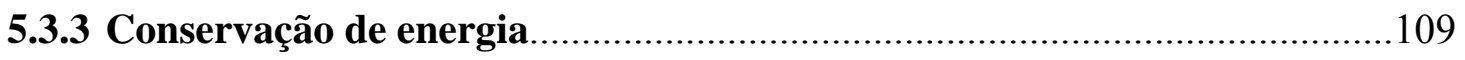

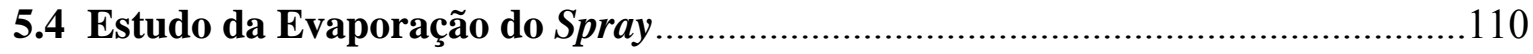

5.4.1 Conservação de massa de vapor no volume de controle..............................112

5.4.2 Conservação de energia no volume de controle.........................................113

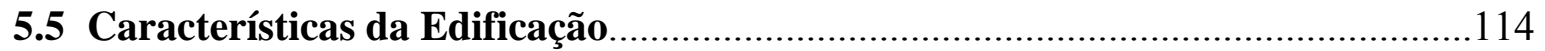

5.5.1 Análise do desempenho térmico de edificações, num intervalo de tempo.. 118

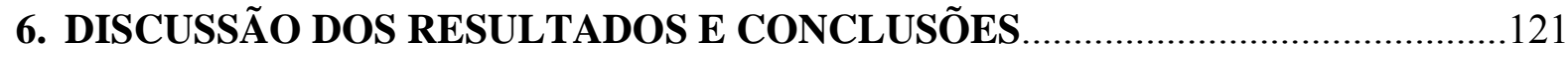

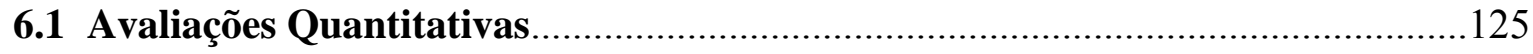

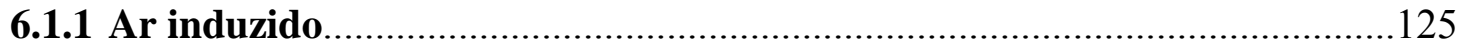

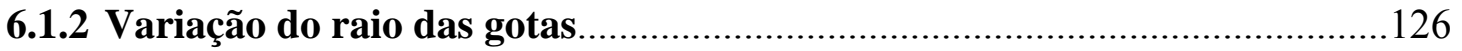

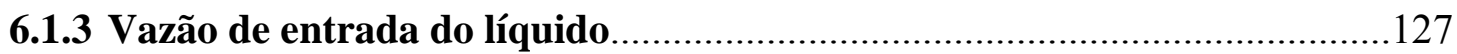

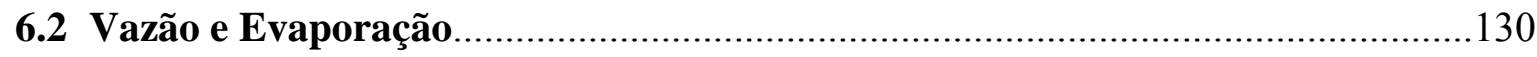

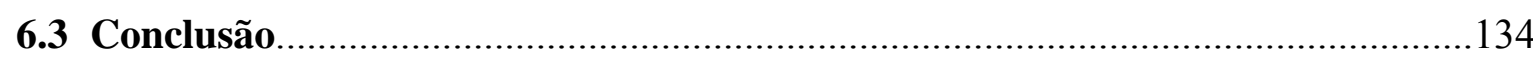

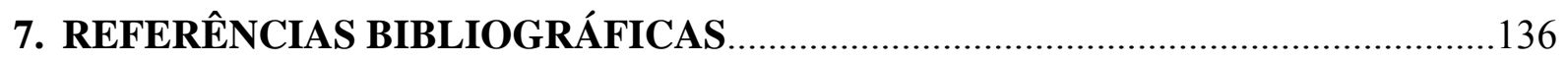




\section{LISTA DE FIGURAS}

Figura 1.1 - Ilustração de uma torre de refrigeração evaporativa por fluxo descendente.

Figura 1.2 - Efeito psicrométrico do equipamento de resfriamento evaporativo de dois estágios. 20

Figura 1.3 - Resfriamento evaporativo com pré-desumidificação por adsorção .21

Figura 1.4 - Representação psicrométrica do resfriamento evaporativo

Figura 1.5 - Umidade relativa (UR) x Temperatura (T): Baseado na zona de conforto térmico. .26

Figura 1.6 - Diagrama $U R \times T$ baseado na zona de conforto térmico norma ISO 77302.

Figura 1.7 - Índice de calor como uma função da umidade relativa e temperatura. .28

Figura 1.8 - Diagrama psicrométrico indicando o padrão de conforto térmico para clima local. .29

Figura 1.9 - Indústria têxtil e de confecções com umidade controlada. .30

Figura 1.10 - Sala de extração de suco de laranja com o sistema de micro aspersão. .31

Figura 1.11 - Pecuária de leite Redução da temperatura e aumento da umidade relativa.

Figura 1.12 - Pecuária de corte - aumento da umidade relativa interna na câmara .32

Figura 1.13 - Aves - Redução do índice de mortalidade e melhoria da conversão alimentar.

Figura 1.14 - Sistema de micro aspersão - redes de aspersão. .35

Figura 2.1 - A névoa produzida em uma instalação interna.

Figura 2.2 - Representação esquemática do diagrama psicrométrico. . .49

Figura 2.3 - Diagrama psicrométrico destacando a zona de conforto térmico. 
Figura 2.4 - Diagrama psicrométrico das condições sob pressão atmosférica........................58

Figura 2.5 - Comportamento adiabático em carta psicrométrica.........................................59

Figura 2.6 - Transferência de calor total do ar para água...................................................61

Figura 2.7- Transferência de calor latente da água para o ar............................................61

Figura 2.8 - Transferência de calor total da água para o ar..............................................61

Figura 3.1 - Temperatura Efetiva para um dia de verão em Kansas City, Missouri..............66

Figura 3.2 - Carta bioclimática, proposta por Givoni (1992) ….......................................67

Figura 3.3 - Temperatura e umidade medidas no pavilhão industrial com sistema de micro

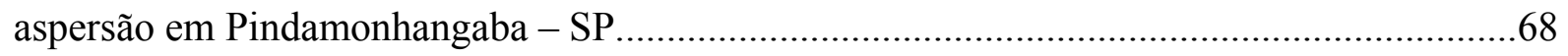

Figura 3.4 - Consumo de energia na nossa estrutura funcional........................................69

Figura 3.5 - Comparação do consumo de energia kWh/CDD..............................................73

Figura 3.6 - Economia verificada com a utilização de pré-resfriamento evaporativo...........74

Figura 3.7 - Pré-resfriamento de condensador aplicado em condicionador de ar..................75

Figura 4.1 - O micro aspersor em operação e o sistema de pressurização..............................78

Figura 4.2 - Detalhe do micro aspersor apresentado pelo fabricante.................................79

Figura 4.3 - Curva de distribuição de frequência de tamanho de gotas de um aspersor de

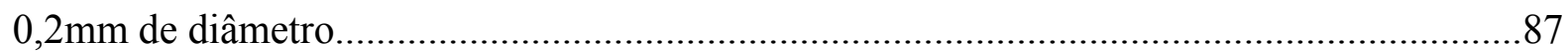

Figura 4.4 - Equação de Clausius Clapeyron para pressão de vapor...................................91

Figura 5.1 - Esquema das zonas e do rompimento do filme líquido de um spray típico.

Figura 5.2 - (a) Principais zonas num spray vertical. (b) Definição de perfil para spray estreito (i) e aberto (ii) 100

Figura 5.3 - (a) Jato de ar induzido pelo movimento do (b) jato de spray líquido................102

Figura 5.4 - Estabelecendo o volume de controle para o spray .....................................111

Figura 5.5 - Conservação de massa de vapor no volume de controle..................................112 
Figura 5.6 - Conservação de energia no volume de controle.

Figura 5.7 - Esquema de integração entre o modelo do spray e o ambiente

Figura 6.1 - Instalação de micro aspersores internos na área, com alta e baixa troca de $\operatorname{ar}$.

Figura 6.2. - Instrumentos de controle mais comuns utilizados nas instalações.

Figura 6.3 - Micro aspersores acoplados a ventiladores

Figura 6.4 - Variação das velocidades do líquido $\left(V_{l}\right)$ e do $\operatorname{ar}\left(V_{a}\right)$

Figura 6.5 - Variação do raio das gotas. 126

Figura 6.6 - variação da vazão de entrada do spray. 126

Figura 6.7 - Variação da umidade relativa em função da vazão.

Figura 6.8 - diagrama do experimento de confinamento do spray e do ar induzido. 131

Figura 6.9 - Experimento com a configuração alterada com a saída de condensado separada do ar induzido. 132

Figura 6.10 - Detalhe da entrada do ar induzido e a posição do aspersor no tubo (montados com 1 e 2 aspersores) 132 
Tabela 1.1 - Escala de sensação térmica ASHRAE............................................................26

Tabela 2.1 - Composição do ar seco no nível do mar..........................................................43

Tabela 2.2 - Calor específico do ar seco..........................................................................44

Tabela 2.3 - Propriedades do vapor da água saturado.....................................................46

Tabela 3.1 - Economia anual de energia com resfriamento evaporativo em cidades dos

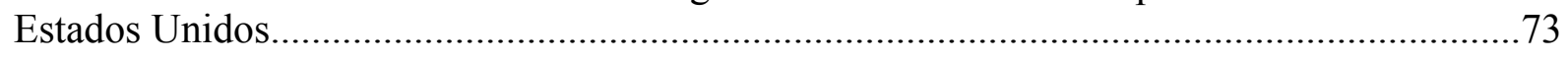

Tabela 4.1 - Vazão dos bicos de atomização em função da pressão......................................80

Tabela 4.2 - Distribuição de tamanho de gotas de um aspersor de $0,2 \mathrm{~mm}$...........................87

Tabela 4.3 - Diâmetros médios das gotas e suas aplicações...............................................88

Tabela 5.1 - Constantes para cálculo da pressão de saturação de vapor da água.................108 


\begin{tabular}{|c|c|}
\hline$a$ & Raio da gota $[m]$ \\
\hline$A$ & Área superficial $\left[\mathrm{m}^{2}\right]$ \\
\hline$A_{0}$ & Área do orifício de descarga $\left[\mathrm{m}^{2}\right]$ \\
\hline$b$ & Coeficiente adimensional \\
\hline$c$ & Tangente do ângulo do spray em relação ao eixo \\
\hline$C_{D}$ & Coeficiente de arrasto \\
\hline$C_{p_{a}}$ & Calor específico a pressão constante do ar seco $\left[\mathrm{kJ} \mathrm{kg}^{-1} \cdot \mathrm{K}^{-1}\right]$ \\
\hline$C_{p_{l}}$ & Calor específico a pressão constante da água $\left[\mathrm{kJ} \mathrm{kg}^{-1} \cdot \mathrm{K}^{-1}\right]$ \\
\hline$C_{p_{v}}$ & Calor específico a pressão constante do vapor de água $\left[\mathrm{kJ} \mathrm{kg}^{-1} \cdot \mathrm{K}^{-1}\right]$ \\
\hline$C_{V}$ & Coeficiente de velocidade \\
\hline$D$ & Diâmetro da gota $[m]$ \\
\hline$D_{A B}$ & Difusividade binária de massa $\left[\mathrm{m}^{2} . \mathrm{s}^{-1}\right]$ \\
\hline$d_{0}$ & Diâmetro do orifício de descarga $[m]$ \\
\hline$d \forall$ & Volume de controle $\left[\mathrm{m}^{3}\right]$ \\
\hline$F N$ & Número de fluxo $\left[\mathrm{m}^{2}\right]$ \\
\hline$h$ & Coeficiente de transferência convectiva de calor $\left[W \cdot \mathrm{m}^{-2} \cdot \mathrm{K}^{-1}\right]$ \\
\hline$h$ & Entalpia específica $\left[\mathrm{kJ} \mathrm{kg}^{-1}\right]$ \\
\hline$h_{a}$ & Entalpia do ar $\left[\mathrm{kJ}^{\mathrm{kg}} \mathrm{kg}^{-1}\right]$ \\
\hline$h_{l}$ & Entalpia do líquido $\left[\mathrm{kJ} \cdot \mathrm{kg}^{-1}\right]$ \\
\hline$h_{v}$ & Entalpia do vapor de água $\left[\mathrm{kJ} \cdot \mathrm{kg}^{-1}\right]$ \\
\hline$h_{a m b}$ & Entalpia do ambiente $\left[\mathrm{kJ} \mathrm{kg}^{-1}\right]$ \\
\hline$h_{\text {mist }}$ & Entalpia da mistura de ar $\left[\mathrm{kJ} \mathrm{kg}^{-1}\right]$ \\
\hline$h_{\text {clim }}$ & Entalpia do ar climatizado $\left[\mathrm{kJ} \cdot \mathrm{kg}^{-1}\right]$ \\
\hline$h_{l_{v}}$ & Calor latente de vaporização $\left[\mathrm{kJ}_{\mathrm{kg}} \mathrm{kg}^{-1}\right]$ \\
\hline$k$ & Condutividade térmica do ar $\left[W \cdot m^{-1} \cdot K^{-1}\right]$ \\
\hline Kn & Número de Knudsen \\
\hline$l$ & Raio do jato de spray $[\mathrm{m}]$ \\
\hline
\end{tabular}




\begin{tabular}{|c|c|}
\hline$L$ & Comprimento $[m]$ \\
\hline$m$ & Massa de ar exterior $[\mathrm{kg}]$ \\
\hline$m_{a m b}$ & Massa de ar ambiente $[\mathrm{kg}]$ \\
\hline$m_{\text {trat }}$ & Massa de ar tratado pelos aspersores $[\mathrm{kg}]$ \\
\hline$\dot{\mathrm{m}}$ & Fluxo de massa evaporada $\left[\mathrm{kg} \cdot \mathrm{s}^{-1}\right]$ \\
\hline$n$ & Taxa de renovação de $\operatorname{ar}\left[h^{-1}\right]$ \\
\hline$N$ & Número de gotas \\
\hline$N A$ & Número de aspersores \\
\hline$N u$ & Número de Nusselt \\
\hline$p_{A}$ & Pressão do ar na superfície da gota $[\mathrm{Pa}]$ \\
\hline$p_{l}$ & Pressão interna da gota $[\mathrm{Pa}]$ \\
\hline$p_{\sigma}$ & Pressão devido às forças de superfície $[\mathrm{Pa}]$ \\
\hline$p$ & Pressão total $[\mathrm{Pa}]$ \\
\hline$p_{v}$ & Pressão parcial de vapor $[\mathrm{Pa}]$ \\
\hline$P_{w b}$ & Pressão de bulbo úmido $[\mathrm{Pa}]$ \\
\hline$\dot{q}$ & Fluxo de calor $\left[W \cdot m^{-2}\right]$ \\
\hline$q_{l}$ & Carga térmica latente $[\mathrm{kW}]$ \\
\hline$q_{s}$ & Carga térmica sensível \\
\hline$q_{r}$ & Calor total trocado entre o ar e a água $[k W]$ \\
\hline$Q_{l}$ & Vazão de líquido $\left[\mathrm{m}^{3} \cdot \mathrm{s}^{-1}\right]$ \\
\hline$R e$ & Número de Reynolds \\
\hline$t$ & Tempo $[s]$ \\
\hline$T$ & Temperatura $[K]$ \\
\hline$T_{a m b}$ & Temperatura do ambiente interno $[K]$ \\
\hline$T_{\text {mist }}$ & Temperatura da mistura de ar $[K]$ \\
\hline$T_{\text {clim }}$ & Temperatura do ar climatizado $[K]$ \\
\hline$V_{a}$ & Velocidade do ar no spray $\left[\mathrm{m}_{\mathrm{s}} \mathrm{s}^{-1}\right]$ \\
\hline$V_{l}$ & Velocidade das gotas na saída do $\operatorname{spray}\left[\mathrm{m} . \mathrm{s}^{-1}\right]$ \\
\hline$V_{l_{0}}$ & Velocidade inicial das gotas (saída do aspersor) $\left[\mathrm{m} . \mathrm{s}^{-1}\right]$ \\
\hline$W$ & Umidade absoluta \\
\hline
\end{tabular}




$\begin{array}{ll}W_{\text {amb }} & \text { Umidade absoluta do ambiente interno } \\ W_{\text {trat }} & \text { Umidade absoluta da mistura de ar tratado } \\ W_{\text {clim }} & \text { Umidade absoluta do ar climatizado }\end{array}$

\section{$\underline{\text { Símbolos Greqos }}$}

$\alpha$

$\alpha_{r}$

$\beta$

$\Delta t$

$\varnothing$

$\lambda$

$\mu$

$v$

$\rho$

$\sigma$

\section{$\underline{\text { Subscritos }}$}

$a$

$l$

$v$

$Z$
Fração de vazio

Difusividade térmica $\left[\mathrm{m}^{2} . \mathrm{s}^{-1}\right]$

Coeficiente de indução de ar

Intervalo de tempo

Representativo da umidade relativa

Relativo as moléculas de ar $[\mu m]$

Viscosidade absoluta $\left[\mathrm{kg} \cdot \mathrm{m}^{-1} \cdot \mathrm{s}^{-1}\right]$

Viscosidade cinemática $\left[\mathrm{m}^{2} . \mathrm{s}^{-1}\right]$

Densidade $\left[\mathrm{kg} \cdot \mathrm{m}^{-3}\right]$

Tensão superficial [N. $\left.m^{-1}\right]$
Referente ao ar

Referente ao líquido (água)

Referente ao vapor de água

Referente a distância percorrida pela gota 
ZAPATERRA, C. L. I., 2016. Estudo da melhoria do desempenho de sistemas de resfriamento evaporativo por micro aspersão de água. Dissertação (Mestrado) - Escola de Engenharia São Carlos, Universidade de São Paulo, São Carlos, 2016.

Disponibilidade dos recursos energéticos junto com o despertar da consciência ambiental criaram um interesse por uma condição climática sensível compatível com os recursos disponíveis. Dentro desse cenário o trabalho se volta à necessidade de se criarem e manterem ambientes industriais termicamente adequados aos processos de produção para minimizar as interferências que as condições ambientais exercem sobre os custos dos processos de produtivos e sobre o consumo energético. Os sistemas de resfriamento evaporativo, por sua vez, têm sido a ferramenta de maior potencial de aplicação na criação de ambientes termicamente adequados aos processos. Este modelo revisto de conforto térmico nos coloca um passo à frente para o aumento eficiência energética na construção de projeto de climatização vinculados a temperaturas interiores que atendam conjuntamente tanto aos ocupantes como às atividades que desenvolvem no interior da área climatizada. Apesar de esse sistema apresentar vantagens operacionais, quando comparado a outros sistemas convencionais, existem certas limitações no seu desempenho. Uma das maiores dificuldades das instalações destes sistemas reside na existência de incertezas em qualquer resultado. Possibilitar um controle dos parâmetros, minimizando os erros de aplicação, evitando criar no ambiente um desconforto de tal grau que inviabilize sua aplicação, é o fundamento deste trabalho. A busca passa a ser pela garantia da aceitabilidade dos resultados do sistema projetado e seus limites de aplicabilidade. O estudo das variáveis que interferem no processo do resfriamento por micro aspersão permitiu desenvolver um processo que alterara esses parâmetros durante o funcionamento do sistema, interferindo, conforme a necessidade no seu desempenho, garantindo a completa evaporação da água micro aspergida.

Palavras-chave: Atomização; Climatização; Conforto Térmico; Micro aspersão, Resfriamento Adiabático, Resfriamento Evaporativo; Transferência de Calor e Massa. 
ZAPATERRA, C. L. I., 2016. Study of improvment the evaporative cooling system performance by water misting systems. M. Sc. Dissertation. São Carlos School of Engineering, São Paulo University.

Energy resources along with an environmental conscience awakening has created an interest in sensitive climate together with a more understanding regarding the use of available resources. Inside this scenario our work focus on the needs of creating and maintaining industrial environments thermally suited to these production processes that seeking to minimize interference that environmental conditions have on the costs of production processes and energy consumption. Evaporative cooling systems, in turn, has been a interesting tool to be used in the creation of thermally suitable environments to these processes. This new revised thermal comfort model puts us a step forward to increase energy efficiency in elaborating air treatment projects linked to indoor temperatures that meet both the occupants and the activities that develop inside the controlled area. Although this system has operational advantages when compared to other conventional systems, there are some limitations in their performance. A major difficulty of the installation envolving these systems is about the existence of uncertainty in any results. To allow the control of these parameters in order to minimize the errors in this kind of application and to avoid creating environmental discomfort to such a degree that prevent the implementation, it is the foundation of this work. The search is to ensure the acceptability of the results of the system designed and their limits of applicability. The study of the variables that affect the cooling process by misting allowed us to develop a process that altered these parameters during operation of the system, interfering, as required in its performance, ensuring complete evaporation of water applied by misting in the area.

Keywords: Atomization; Air treatment; Thermal comfort; Mist System; Adiabatic Cooling, Evaporative Cooling; Heat and mass transfer. 


\section{INTRODUÇÃO}

\subsection{Considerações Iniciais}

Em todo o mundo há uma crescente busca por mudanças envolvendo os processos produtivos por motivos ligados, basicamente, a três preocupações: meio ambiente, energia e economia global. Neste contexto, apesar da matriz energética brasileira ser aproximadamente $46 \%$ renovável, valor muito superior à média mundial de $12 \%$, ainda há muito que se fazer no que se refere à economia de energia. Basta lembrar de crises como a de 2001, quando a ausência de chuvas limitou a produção das hidrelétricas e, consequentemente, levou o país a um longo período de racionamento de energia elétrica, influenciando direta e indiretamente todos os setores da economia e da política brasileira (VICHI e MANSOR, 2009). Deste modo, a utilização mais eficiente da energia é um assunto de extensa pesquisa nas nossas universidades e de grande interesse nas empresas devido à criação de normas, formas e protocolos para utilização mais consciente dos recursos disponíveis e ao ganho financeiro proporcionado. Dentre tais estudos, esta dissertação se volta para sistemas de refrigeração, nos quais a economia energética está diretamente ligada à eficiência de funcionamento dos seus componentes.

A utilização de sistemas de refrigeração contribui não só para a conservação de produtos perecíveis por mais tempo, mas também na manutenção de ambientes industriais e na obtenção de conforto térmico, de modo que sua abrangência compreende diversas áreas da engenharia.

Empresas de diversos segmentos produtivos têm atestado a necessidade de se criar e manter ambientes industriais termicamente adequados a esses processos de produção no sentido de minimizar as interferências que as condições ambientais exercem tanto nos processos de produtivos, como no consumo energético e nos custos de produção.

Deve-se ter em mente que um ciclo de refrigeração é um sistema térmico que transfere energia em forma de calor de uma região de baixo potencial energético para uma região de alto potencial energético. Como o saldo de variação de energia é positivo, significa que a energia adentra no sistema, portanto, em um ciclo de refrigeração se faz necessária uma fonte de energia externa (FERZOLA, 2010). Por conseguinte, há um constante interesse em 
tornar esses sistemas mais eficientes e, desse modo, promover uma economia energética considerável.

Em se tratando de conforto térmico, sistema de ar-condicionado tem se tornado popular e, até mesmo, uma necessidade na vida para a obtenção de ambientes termicamente confortáveis, entretanto consome uma grande quantidade de energia ao mesmo tempo. Dada a crescente urgência em se economizar energia, uma tecnologia mais eficiente em relação ao ar condicionado é, obviamente, altamente desejável. Nessa busca de tecnologias mais eficientes, o processo de resfriamento evaporativo tem sido visto como uma opção atrativa, quando comparado a outros já existentes como compressão de vapor, absorção / adsorção e sistemas de refrigeração termoelétricos, devido ao seu baixo custo e alto potencial de eficiência. Porém, estes sistemas têm seu desempenho limitado as condições de clima seco e quente e climas temperados.

Buscando melhorar o desempenho dos sistemas de resfriamento evaporativo, uma extensa pesquisa tem sido conduzida afim de analisar o grau de influência de fatores tais como: temperatura e umidade do ar, temperatura da água, velocidades envolvidas no processo de evaporação, condução de calor, propriedades de troca de calor e massa, ponto de orvalho, entre outros. Vários sistemas de resfriamento que buscam otimizar a eficiência da evaporação têm sido desenvolvidos. Dentre esses podemos citar, como exemplo, as torres resfriamento evaporativos que fazem da utilização de elementos umedecedores para se obter refrigeração evaporativa no alto da torre, tornando o ar mais denso, aumentando a pressão. Essas torres, também conhecidas como "torres de refrigeração evaporativa por fluxo descendente", estão representadas na figura 1.1 e o resfriamento evaporativo de dois estágios, direto e indireto, ilustrado na figura 1.2, sempre com o foco na maximização do efeito do resfriamento.

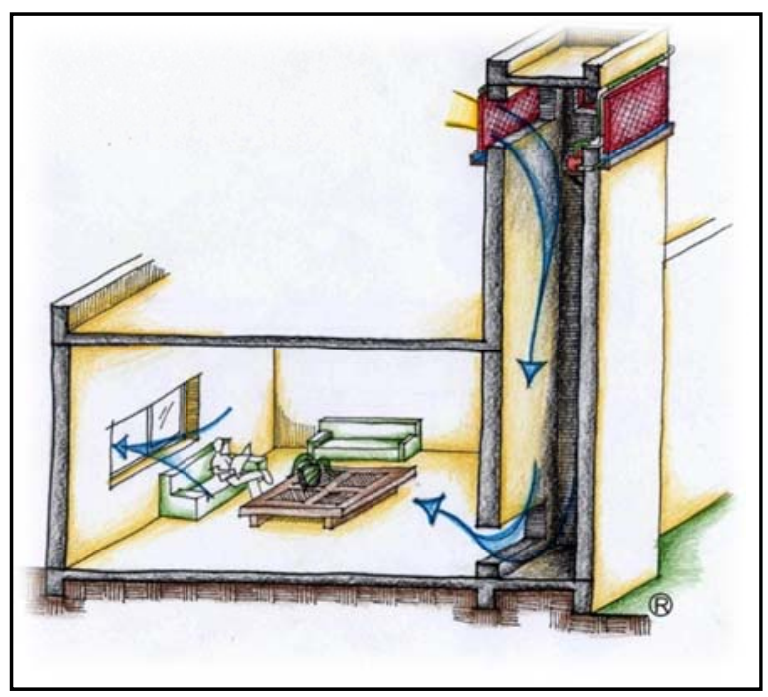




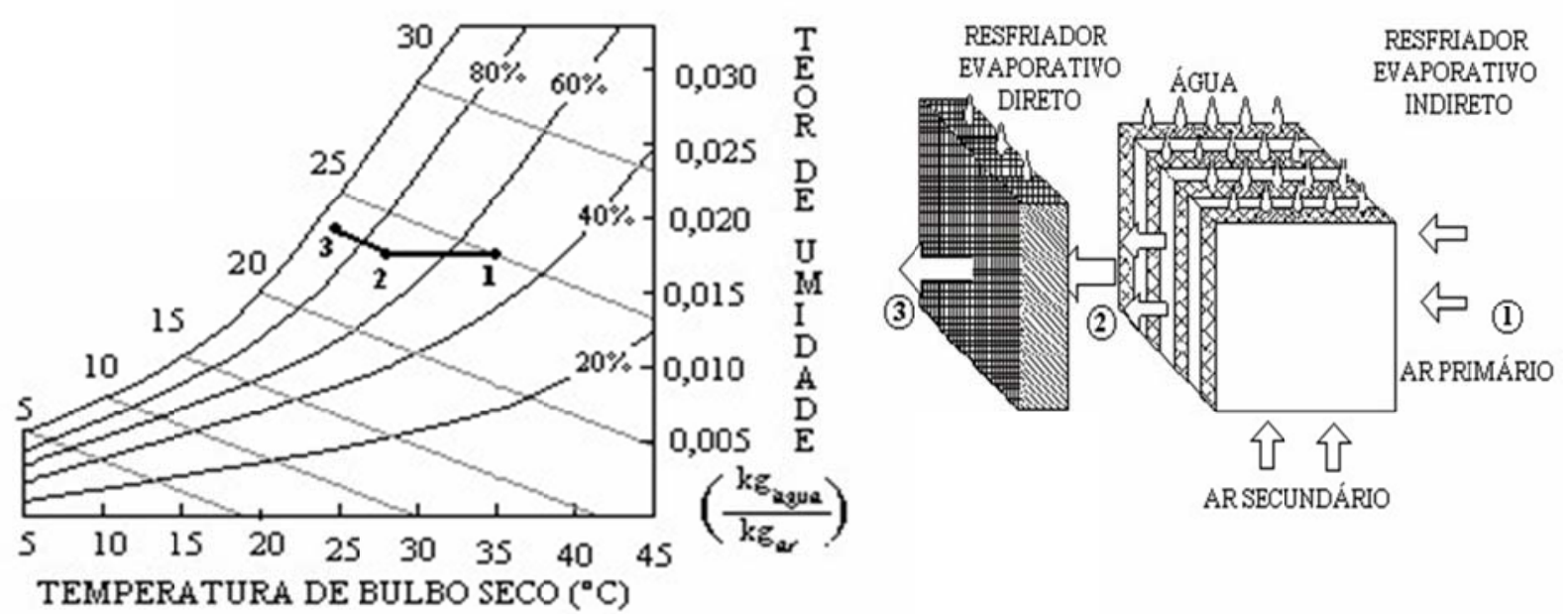

Figura 1.1 - Ilustração de uma torre de refrigeração evaporativa por fluxo descendente.

Fonte: http://projeteee.ufsc.br

Figura 1.2 - Efeito psicrométrico do equipamento de resfriamento evaporativo de dois estágios.

Fonte: CAMARGO, 2003

Os sistemas que vem sendo estudados buscam o aumento da eficiência dos processos de resfriamento evaporativo, que pode ser descrito como a relação entre a queda real da temperatura do bulbo seco produzida pelo sistema e a temperatura do bulbo seco que se poderia atingir se o sistema de resfriamento fosse 100\% eficiente, sendo o ar de saída, saturado. Nesse caso, a temperatura do bulbo seco do ar de saída seria igual temperatura do bulbo úmido do ar admitido. O comparativo com o sistema de resfriamento ideal teria a temperatura do bulbo seco e o ponto de orvalho igual a temperatura do bulbo úmido (TRANE, 1978). Essa condição deixa claro que quanto maior a umidade relativa do ar de admissão tanto menor será a eficiência da queda de temperatura do processo evaporativo.

Uma outra tecnologia que tem surgido é de sistemas de resfriamento evaporativos acoplados a desumidificadores por adsorção. Um sistema típico, ilustrado na figura 1.3, combina o sistema de desumidificação, que utiliza um cilindro rotativo impregnado de material dessecante, com resfriadores evaporativos diretos e indiretos, permitindo o fornecimento de ar em condições de temperatura, umidade e velocidade que propiciam conforto térmico ambiental, mesmo em regiões de clima equatorial e tropical como o Brasil (CAMARGO at.al, 2005). 


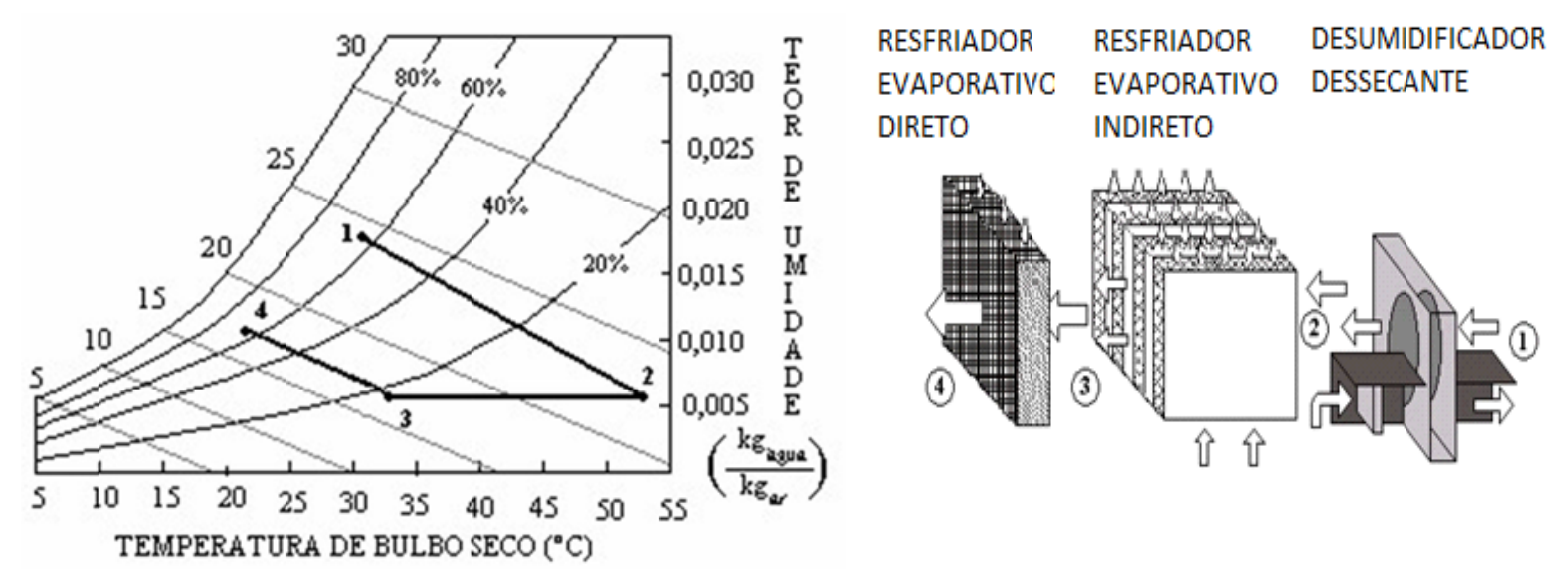

Figura 1.3 - Resfriamento evaporativo com pré-desumidificação por adsorção Fonte: CAMARGO, 2003

A aplicação de desumidificadores adsortivos acoplados a sistemas de resfriamento evaporativos começaram a surgir a partir dos trabalhos desenvolvidos por BELDING E DELMAS (1997) e posteriormente por ZHENQIAN et al (2000).

Esses autores recomendam que, na utilização de sistemas de resfriamento evaporativo acoplados a pré-desumidificadores por adsorção, deve-se observar se relação entre a área superficial do dissecante e sua massa é inversamente proporcional, pois essa condição contribui para uma maior eficiência do processo de desumidificação. Também a relação entre a pressão de vapor no ar de capitação e na superfície do dissecante, pois essa condição contribui para uma maior capacidade do material em adsorver a umidade.

O carvão ativado foi um dos primeiros adsorventes conhecidos e é, até hoje, um dos mais utilizados. Geralmente é produzido pela decomposição térnnica de um material carbonáceo seguido pela ativação com vapor ou dióxido de carbono em altas temperaturas.

Resfriamento evaporativo, quando existem condições ambientais de altas temperaturas e baixas umidades relativas, ou seja, climas quentes e secos, terá sempre um desempenho de refrigeração satisfatório, desde que adequadamente projetado, instalado e mantido. Dessa forma, os benefícios alcançados com a aplicação de sistemas de resfriamento evaporativo são geralmente percebidos em termos de eficiência operacional. As aplicações deste sistema agregam vantagens importantes como o aumento da qualidade do ar interno, por exemplo. O tamanho e a quantidade de partículas removidas do ar é maior do que em filtros convencionais e se compara a filtros HEPA (PALMER, 2002). Além disso, podemos considerar como vantagem, também, a segurança e a confiabilidade proporcionada pelos requisitos ou protocolos de manutenção simplificados. 
No sistema de resfriamento evaporativo, ao contrário dos sistemas típicos de ar condicionado que utilizam refrigeração por compressão de vapor ou refrigeração por absorção, é a adição de vapor de água no ar o que induz à redução da temperatura desse ar, ou seja, a água e o ar úmido não saturado entram em contato e provocam a evaporação, resultando na queda da temperatura e no aumento da quantidade de vapor no ar. Quanto maior a área de contato entre o ar e água, maior a ocorrência de evaporação. O resultado é um maior resfriamento e aumento da umidade.

A energia necessária para evaporar a água é retirada do ar sob a forma de calor sensível. Esse calor é transferido do fluido de maior temperatura, no caso o ar, para o de menor temperatura, o que provoca a queda da temperatura do ar e, em seguida, convertido em calor latente, responsável pela mudança de estado da água de líquido para vapor, enquanto o ar permanece com seu valor de entalpia constante. Esta conversão de calor sensível ao calor latente é um processo adiabático porque não há nenhum ganho ou perda de calor. Sendo assim, o processo de resfriamento evaporativo provoca uma queda na temperatura do ar proporcional à queda de calor sensível e um aumento da umidade proporcional ao ganho de calor latente.

Resfriamento evaporativo pode ser visualizado na carta psicométrica: Encontra-se a condição inicial do ar e movendo-se ao longo de uma linha de entalpia constante em direção a

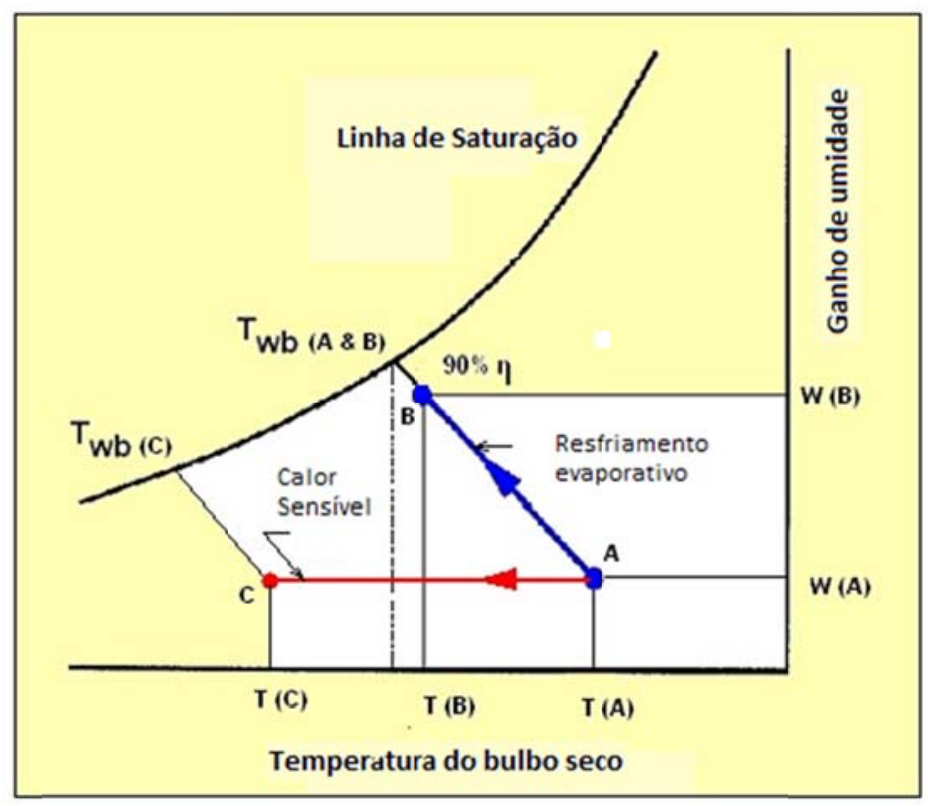

um estado de maior umidade. 
Figura 1.4 - Representação psicrométrica do resfriamento evaporativo Fonte: BHATIA, 2012

Esta evaporação resulta em uma temperatura reduzida e um aumento do teor de vapor no ar e, para que a água se evapore, uma energia é necessária, o calor é necessário. $A$ British Termal Unit, ou BTU, é uma das unidades usada para medir o calor. Para evaporar um galão de água requer quase 8.700 BTU de calor. No caso do resfriamento evaporativo, essa é a quantidade de calor a ser retirada do ar para que ocorra a evaporação, ou seja, para cada grama de água evaporada se retira 590 calorias, na forma de calor sensível.

Conforme o ar entra em contato com a água, esse a agrega em certa quantidade. A quantidade de água que agora compõe o ar depende da quantidade de água pré-existente nesse ar. Dessa forma, quando o ar quente e não saturado entra em contato com uma superfície molhada, parte da água é evaporada. À medida que a vaporização ocorre, o ar e a água resfriam-se até que o ar esteja saturado, conforme demonstrado na figura 1.4. Portanto, a energia requerida para evaporar a água é suprida pelo ar com consequente umedecimento do ar não saturado e redução da temperatura de bulbo seco.

O processo de resfriamento só é possível graças à interação que há entre a transferência de calor e a transferência de massa. A água absorve calor do ar na evaporação e calor é retirado do vapor na condensação. O contato livre e prolongado entre a água e o ar resulta num estado de equilíbrio em que normalmente o ar estará saturado. Quanto maior a temperatura do ar, maior será a quantidade de vapor no ar, necessária para saturá-lo.

A função da aplicação do sistema de resfriamento evaporativo é fazer com que a evaporação ocorra de forma controlada a fim de se obter resultados que produzam efeitos em termos de resfriamento, umidificação e consequente melhoria da qualidade do ar ambiente. Atingir o ponto de orvalho, nesse caso, seria ultrapassar o limite do princípio evaporativo, pois nesse ponto a ocorrência da evaporação cessa. Por outro lado, quanto mais baixa for a umidade relativa maior a velocidade com que a evaporação ocorre e maior o grau de resfriamento que pode ser alcançado.

Ficam determinadas, assim, as variáveis que tem impacto direto sobre os efeitos resultantes do processo evaporativo, no caso a temperatura e umidade relativa e os parâmetros que o influenciam, como aqueles que interferem na velocidade com que a evaporação ocorre. A eficiência energética pode ser observada quando espaços, cujo objetivo é o de alterar as 
características térmicas a favor da necessidade do processo de produção e dos trabalhos ali desenvolvidos, têm a umidade e temperatura, monitorados.

Segundo CHAPPELLS E SHOVE (2009), a manutenção destes espaços em condições de clima de conforto adequados as necessidades das atividades lá desenvolvidas é o modo mais eficiente de se economizar energia.

Existem, hoje, mais de quatro milhões de unidades de sistemas de refrigeração de ar evaporativos em operação nos Estados Unidos que fornecem uma estimativa de economia anual de energia equivalente a 12 milhões de barris de petróleo e redução anual de 5,4 bilhões de libras de emissões de dióxido de carbono. Em se tratando de sistemas de compressão de vapor como ar condicionado, estes sistemas também evitam a necessidade de 24 milhões de libras de refrigerante tradicionalmente usado em VAC residencial (VICHI e MANSOR, 2009).

Sendo assim, a percepção das condições ambientais e do sentimento de conforto térmico passa a ser o foco principal para se estabelecer os parâmetros de controle da climatização dos espaços.

\subsection{Conforto Térmico}

Determinar os parâmetros ou os limites das variáveis envolvidas no processo de resfriamento evaporativo é a base para se chegar às condições climáticas termicamente adequadas em relação as atividades desenvolvidas ou, simplesmente, confortáveis para as pessoas que estão lotadas no espaço climatizado. Zona de conforto térmico que chamamos aqui, é a determinação destes parâmetros.

Com o conhecimento destes limites ou das condições ideais de conforto climático, os sistemas de controle podem ser configurados para que atendam as necessidades do utilizador com maior desempenho e assim, utilizando a energia de forma mais eficiente. Fica claro que atingir as condições de conformo térmico passa a ser estabelecer corretamente os parâmetros ideais de temperatura e umidade relativa e os controles necessários para se adequar as condições de conforto térmico ao espaço climatizado.

O conforto térmico é um conceito importante para a adequação dos espaços climatizados buscando uma própria satisfação de bem-estar, relacionada com a temperatura. 
Representa aquele ponto no qual a pessoa necessita consumir uma menor quantidade de energia para se adaptar ao ambiente circunstante. Ajustar os parâmetros de temperatura e umidade relativa, aliados a velocidade com que o ar circula no ambiente, é o que vai nos dar a sensação térmica de conforto. Esta notação fornece uma compreensão, uma ótica sobre a aplicação do conceito de conforto térmico, especialmente no que diz respeito a necessidade de se representar a umidade e sua relação com a temperatura.

Os fatores que têm influência relevante sobre o conforto térmico dos espaços controlados, podem ser expressos fatores ambientais e pessoais.

Fatores ambientais:

- Temperatura do bulbo seco

- Radiação térmica

- Umidade relativa

- Velocidade do ar

Fatores pessoais:

- Metabolismo

- Temperatura da pele

- Roupa que usa

- Atividades pessoais e produtivas

Considerando esses fatores como perturbadores climáticos, apresentar indicadores adequados tanto a necessidade dos seus utilizadores, como também às atividades desenvolvidas, significa aumento da eficiência na utilização da energia dispensada, ou seja, usando energia apenas onde realmente for necessário.

O conforto térmico é em grande parte um estado de espírito, separado de equações de transferência de calor e massa e seus respectivos saldos de energia. No entanto, a percepção de conforto deverá ser influenciada por variáveis que afetam a transferência de calor e massa no nosso modelo de balanço energético. Percepção das condições ambientais e do sentimento de conforto estão relacionados com a produção de calor metabólico, a sua transferência para o meio ambiente, e os ajustes decorrentes da temperatura do corpo.

Um projeto apropriado providencia massa térmica suficiente para reduzir as oscilações máximas de temperatura e torna ajustáveis os parâmetros de temperatura e 
umidade relativa, a fim de que possam responder as mudanças de condições climáticas ou mesmo para substituir ou atuar conjuntamente a outros sistemas ativos de aquecimento ou resfriamento, uma vez que o objetivo é conseguir manter a temperatura desejada ou, ao menos, atenuar os efeitos do clima exterior.

A forma mais comum para caracterizar o conforto térmico para fins de dados de projeto tem sido a de correlacionar os resultados dos experimentos com pessoas e as variáveis de análise térmica. Tratamos de relacionar as sensações de pessoas executando diferentes atividades em ambientes com diferentes temperaturas do ar, diferentes umidades, e diferentes velocidades e padrões de fluxo de ar. O nível de conforto é caracterizado utilizando a escala ASHRAE de sensação térmica, apresentada abaixo, na tabela 1.1.

Tabela 1.1 de sensação ASHRAE

\begin{tabular}{cc}
\hline Value & Sensation \\
\hline+3 & Hot \\
+2 & Warm \\
+1 & Slightly warm \\
0 & Neutral \\
-1 & Slightly cool \\
-2 & Cool \\
-3 & Cold \\
\hline
\end{tabular}

Escala térmica

Fonte: ASHRAE. Standard 55, 2013

A resposta da sensação térmica é a dada pelo voto médio previsto (PMV), que nada mais é que a média de um certo número de indivíduos, utilizando a escala ASHRAE de sensação térmica.

Considerando os efeitos externos como radiação térmica e velocidade do ar, efeitos que são difíceis de controlar e medir, a ASHRAE apresenta o seguinte diagrama para caracterizar definir uma região de conforto, definida como zona de conforto térmico. 


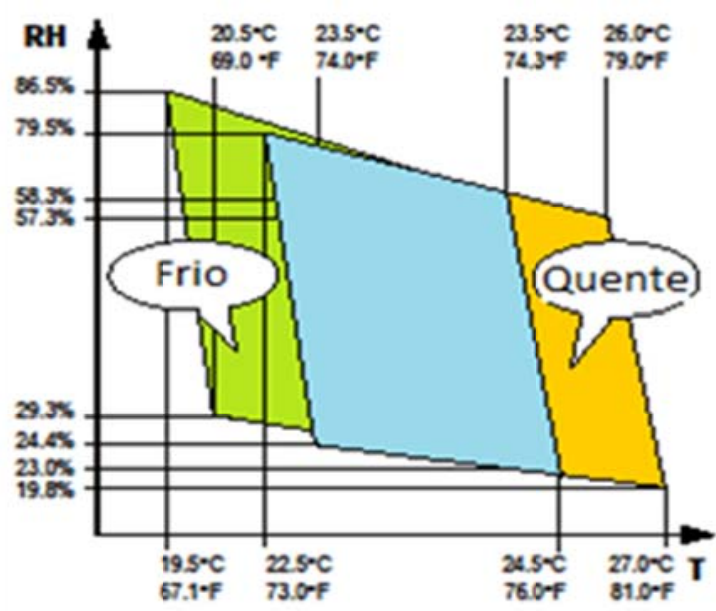

Figura 1.5 - Umidade relativa $(\mathrm{RH})$ x Temperatura $(\mathrm{T})$ : Baseado na zona de conforto térmico Fonte: ASHRAE. Standard 55-1992

O efeito da sensação térmica de uma condição climática de alta temperatura com alta umidade relativa é refletida pelos limites oblíquos do diagrama, para os limites de temperatura máximo e mínimo, indicados figura 1.5. Isto tem um impacto direto sobre os sistemas de controle de climatização. A eficiência da energia consumida se dá quando os espaços climatizados são monitorados para ambos, umidade e temperatura. Um espaço com alta temperatura e baixa umidade relativa, por exemplo, necessita de ajustes mínimos na temperatura e umidade para se atingir uma condição de conforto térmico, com um mínimo de energia. Se o ambiente fosse controlado apenas pelo parâmetro temperatura, poderíamos ter indicação de necessidade de aquecimento ou resfriamento, mesmo dentro da zona de conforto térmico.

Os limites de uma zona de conforto térmico, além das normas ASHRAE, também são tratados nas normas ISO 77302, representado na figura 1.6. Entretanto, essa norma negligencia o fato de que a maior das temperaturas pode ser alcançada a baixa umidade. Nela, os limites de temperatura superior e inferior são verticais. Esta norma é utilizada, normalmente, em aplicações para implementação de sistemas de ar acondicionado. 


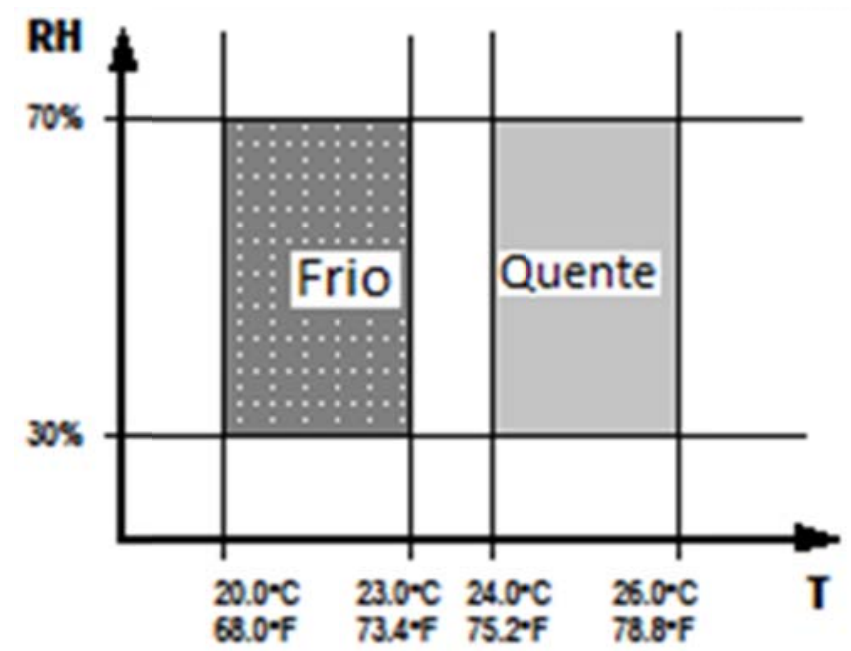

Figura 1.6 - Diagrama UR/T baseado na zona de conforto térmico norma ISO 77302 Fonte: FANGER, 1984

O Índice de Calor (IC), figura 1.7, é outra abordagem que considera as condições de conforto térmico. É uma medida que dá a sensação térmica quando se relaciona a temperatura real do ar com a umidade relativa respectiva, ou seja, o IC indica como o corpo humano se sente naquela temperatura. A definição do índice de calor é do Serviço Nacional de Meteorologia e Previsão do Tempo da Administração Nacional Oceânica e Atmosférica (NOAA).

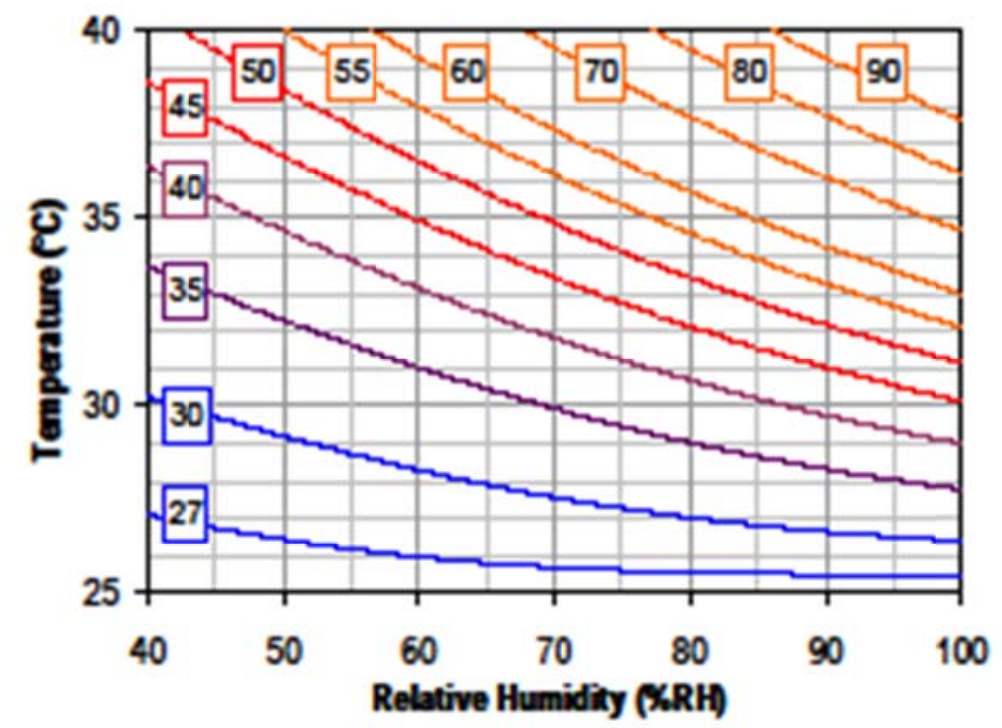

$<30^{\circ} \mathrm{C}$ : nenhum desconforto

$30-40^{\circ} \mathrm{C}$ : algum desconforto

$40-45^{\circ} \mathrm{C}$ : grande desconforto

$>45^{\circ} \mathrm{C}$ : perigoso

$>54^{\circ} \mathrm{C}$ : insolação iminente

Figura 1.7 - Índice de calor como uma função da umidade relativa e temperatura Fonte: NOAA, 1999

O que há de comum entre a normas ASHRAE, standart 55 e ISO 77302 e o conceito de IC da NOAA é o estabelecimento de uma combinação satisfatória, nesse ambiente, 
envolvendo a temperatura e umidade relativa, buscando uma temperatura mais adequada as atividades ali desenvolvidas e a vestimenta usada pelas pessoas que atuam no espaço climatizado. Em estudos empíricos executados, o leque de temperaturas que se pode referenciar como confortável resulta mais amplo do que se esperava. As pessoas habituadas a temperaturas elevadas, por exemplo, consideram estas aceitáveis e sugerem um grau de aclimatação que altera e amplifica o leque teórico da aceitabilidade térmica.

Daqui se conclui não haver necessidade de uniformizar as temperaturas internas do espaço climatizado ou de todo globo, podendo cada região do mundo adotar as temperaturas convenientes para o respectivo clima local e a estação do ano (ROAF e HANCOCK, 1992). Ter em conta tanto a adaptabilidade das pessoas como a das atividades desenvolvidas nestes locais, significa podermos ampliar as condições ambientais e definições acerca de conforto térmico.

Isto significa que a análise das condições climáticas se torna a base para se estabelecer os parâmetros de conforto térmico, sugerido pelas normas e qual a melhor alternativa do sistema de condicionamento do ar para atingir as condições térmicas adequadas a esses ambientes. No diagrama psicrométrico da figura 1.8 é possível observar qual a melhor alternativa do sistema de condicionamento do ar para atingir a zona de conforto térmico, em função da temperatura de bulbo seco e umidade relativa. Nesse diagrama, observa-se até que temperatura de bulbo úmido referenciado no clima local, possibilita a aplicação de sistemas de resfriamento evaporativos, indicando essa análise como a ferramenta mais assertiva na determinação dos padrões de conforto térmico. 


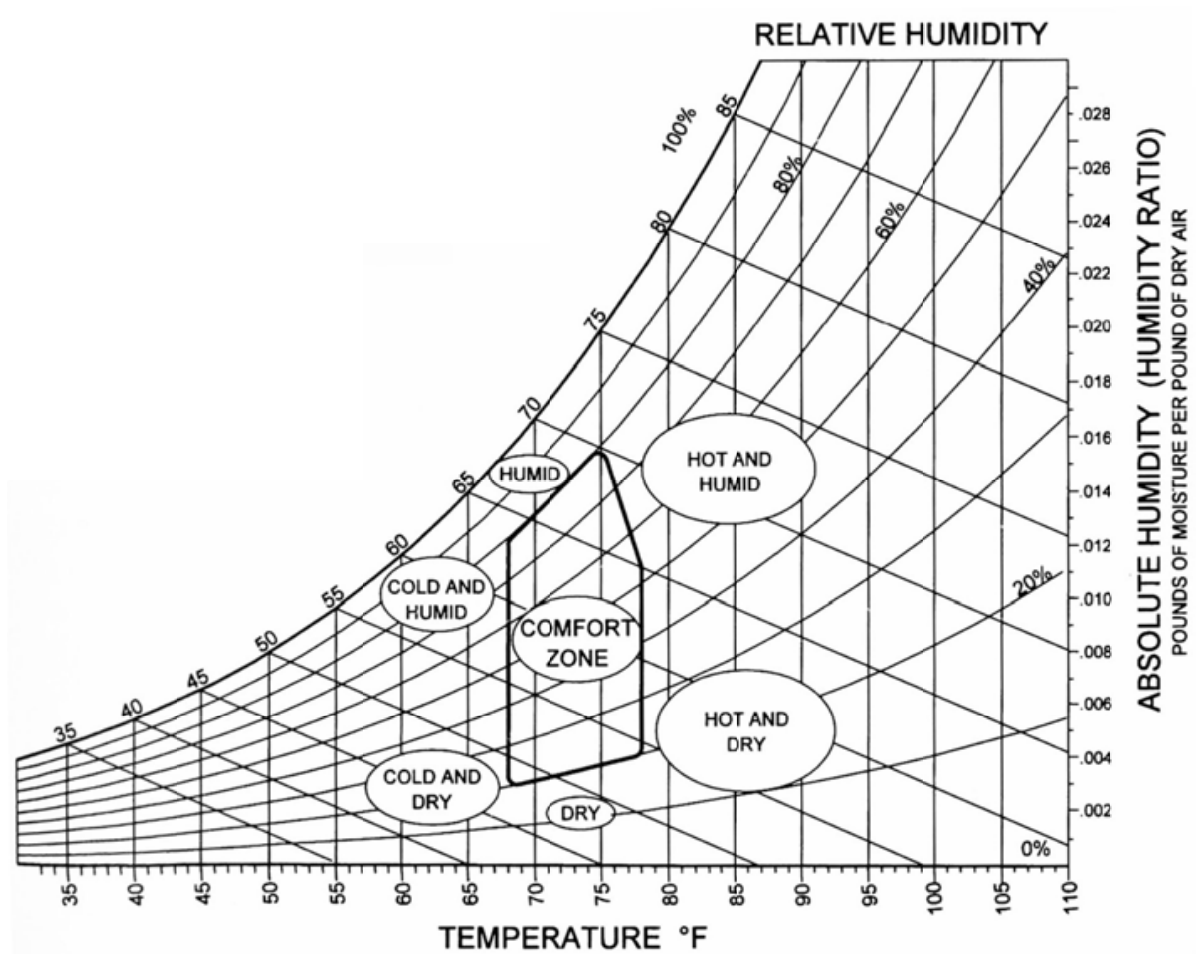

Figura 1.8 - Diagrama psicométrico indicando o padrão de conforto térmico para clima local. Fonte: LECHNER, 2000

\subsection{Motivação e Justificativa}

Nestes últimos anos, o que se observa em empresas de diversos segmentos produtivos é uma tendência de incluir no ambiente de produção, sistemas de resfriamento evaporativo para se obter condições térmicas, que seriam, a princípio, mais adequadas a cada processo. O problema comum que poderia até chamar de clássico, refere-se a interferência das condições ambientais no processo de produção.

Algumas empresas trabalhadas, onde tais interferências ambientais se mostraram mais significativas, estão relacionadas ao segmento têxtil e confecção, de extração de suco de laranja, agrícola e aí destacando a pecuária de leite, de corte e aves, além da produção de mudas de um modo geral.

Para exemplificarmos até que nível as interferências ambientais prejudicam os processos produtivos, podemos usar como base alguns destes projetos, já desenvolvidos, cujo objetivo sempre era o de alterar as características térmicas a favor da necessidade do processo de produção e dos trabalhos ali desenvolvidos.

No caso do segmento têxtil e de confecção a umidade relativa do ar ambiente está diretamente relacionada ao desempenho dos teares, pois as fibras naturais vegetais diminuem 
a carga de ruptura a tração quando a umidade relativa ambiente está menor que a umidade relativa padrão $(65 \%)$, ou seja, quanto mais estiverem úmidas as fibras, mais as fibras serão resistentes à tração. Além disso, valores de umidade abaixo dos valores padrão aumentam substancialmente a quantidade de fibra particulada em suspensão de ar, tornando o ambiente insalubre. A figura 1.9 mostra um galpão industrial têxtil com umidade controlada.

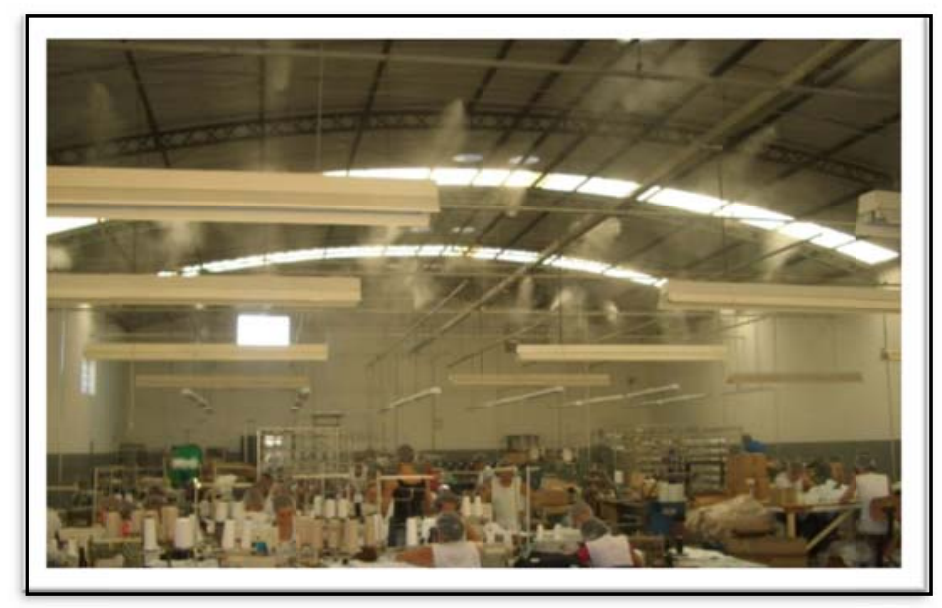

Figura 1.9 - Indústria têxtil e de confecções com umidade controlada Fonte: Instalação executada pelo autor em 2007 - Campo Mourão - PR

$\mathrm{Na}$ extração de suco de laranja, o modelo de extratora adotado por todas as empresas nacionais do setor é o Brown extractor fabricado pela FMC Technologies. Esse processo é aberto onde o fruto entra na extratora e é comprimido e o suco coletado sai das extratoras por meio de tubulações na parte inferior do equipamento. Os compostos responsáveis pelo aroma e sabor característicos da laranja encontram-se presentes em três diferentes subprodutos obtidos do processamento do suco que são: a essência aquosa (water phase), a essência oleosa (oil phase) e o óleo essencial (cold pressed oil) presente na casca da laranja e perdido, principalmente, na etapa de extração do suco pela sua volatilização durante o processo. Quanto mais baixas forem as condições de umidade relativa no ambiente maior a perda e a insalubridade da sala de extração. A figura 1.10, abaixo, apresenta uma instalação. 


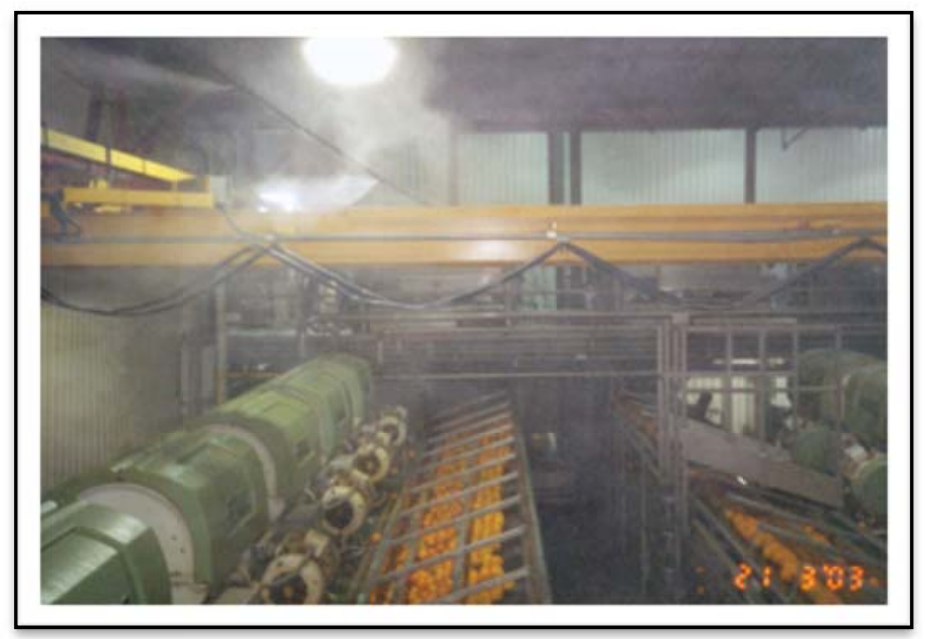

Figura 1.10 - Sala de extração de suco de laranja com o sistema de micro aspersão Fonte: Instalação executada pelo autor em 2002 - Lake Wales - Fl - USA

No que se refere a pecuária de leite, figura 1.11, as condições ambientais exercem fortes influências nos bovinos como em todos os seres vivos. Diretamente, afetam as funções orgânicas envolvidas na manutenção do equilíbrio interno do organismo (homeostasia). As raças de origem europeia (Bos taurus) determinam uma faixa de umidade e temperatura críticas, nas quais caem o consumo de alimentos e a produção de leite. Tais faixas de temperaturas estão entre 24 e $26^{\circ} \mathrm{C}$ para a raça Holandesa, entre 27 e $29^{\circ} \mathrm{C}$ para a Jersey e acima de $29,5^{\circ} \mathrm{C}$ para a Pardo-Suíça com faixas umidades abaixo de 50\% (MEDEIROS E

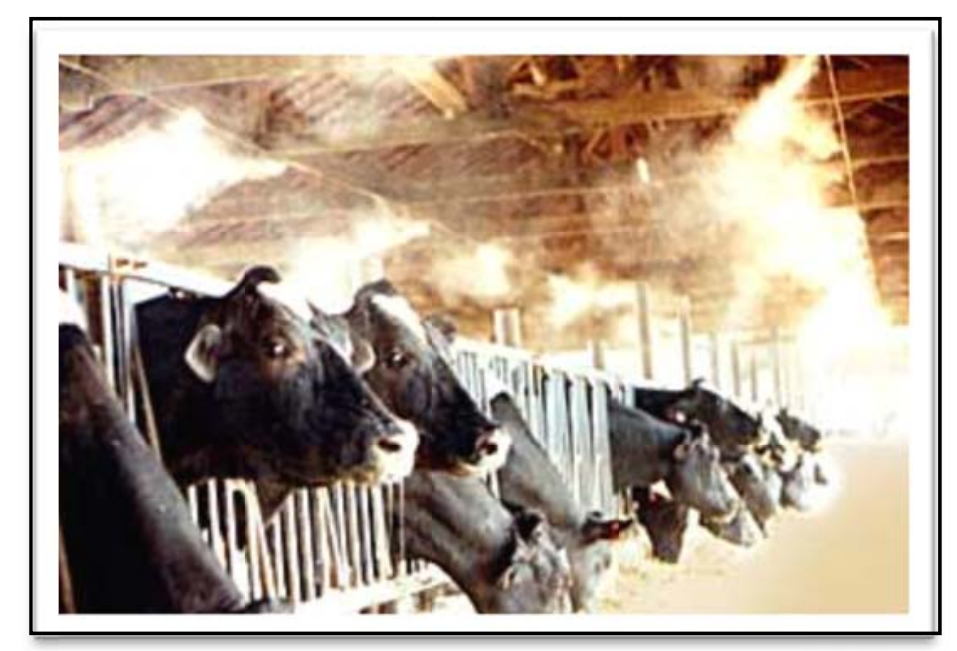

RIBEIRO, 2016).

Figura 1.11 - Pecuária de leite Redução da temperatura e aumento da umidade relativa Fonte: Instalação executada pelo autor em 2002 - Votuporanga - SP 
Em relação a pecuária de corte, a carcaça, logo após o abate é armazenada em uma câmara fria a $4^{\circ} \mathrm{C}$. Sob esta condição desenvolve-se o processo de maturação, ou seja, a estrutura muscular vai paulatinamente sendo degradada e provocando o amaciamento. Entretanto, durante o processo de resfriamento ocorre a quebra de peso, ou seja, a diferença de peso entre a carcaça quente (logo após o abate) e a mesma carcaça que foi armazenada em uma câmara fria a $4{ }^{\circ} \mathrm{C}$. Essa quebra é da ordem de 1,9 a 2,7\% e ocorre principalmente pela evaporação da água que migra da carcaça para a câmara fria devido a baixa umidade relativa no interior da câmara, figura 1.12. Essa diferença de peso encontrada provoca um sério problema econômico no frigorífico (MEDEIROS E RIBEIRO, 2016).

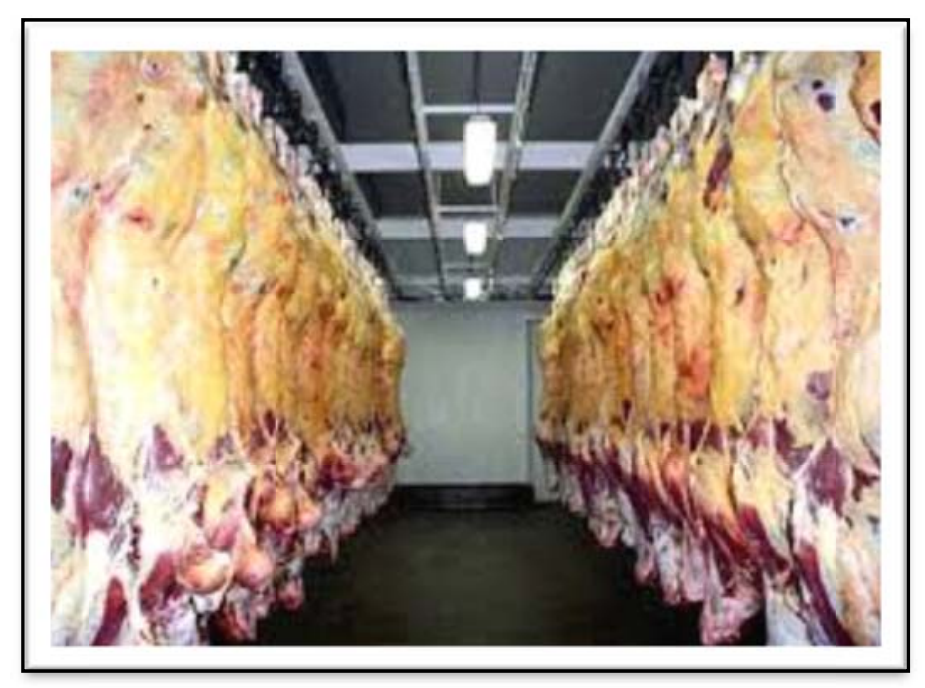

Figura 1.12 - Pecuária de corte - aumento da umidade relativa interna na câmara Fonte: Instalação executada pelo autor em 2000 - Rio do Sul - SC

Os maiores benefícios, entretanto, obtidos pelo controle da temperatura e umidade vem dos frangos de corte, observados na figura 1.13. O desempenho zootécnico dos animais é determinado pelo índice de mortalidade, respostas fisiológicas e o comportamento. Verificouse que, em ambientes com índice de temperatura de globo e umidade (ITGU) variando de 69 a 77, as aves mostraram-se calmas, normalmente dispersas e altamente produtivas (ENGENHARIA NA AGRICULTURA, 2005). 


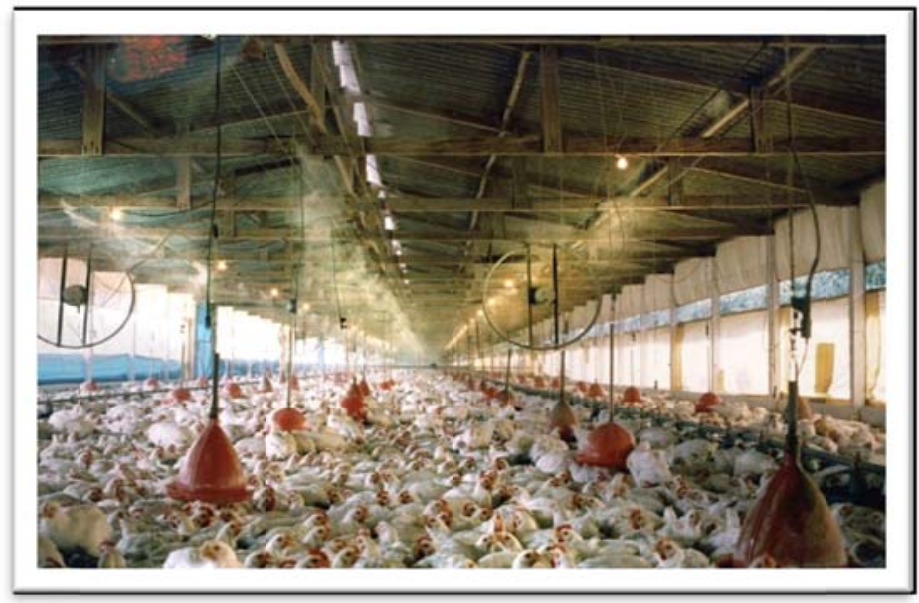

Figura 1.13 - Aves - Redução do índice de mortalidade e melhoria da conversão alimentar

Fonte: Instalação executada pelo autor em 2001 - Guapiaçu - SP

Inúmeras outras aplicações envolvendo outros segmentos produtivos apresentaram resultados bastante satisfatórios. Dentre elas podemos citar estufas de produção de mudas e plantas, instalações para o pré-resfriamento do ar, tanto em sistemas de condicionamento de ar, como também, de transformadores a óleo e em aplicações para o controle de odores e poeiras.

A cogeração de energia também pode ser classificada com um segmento potencial para aplicação deste sistema. Estudos prévios têm demonstrado vantagens no uso de painéis evaporativos para resfriar o ar de alimentação de turbinas a gás (GUIMARÃES, 2000; BASSILY, 2001). O rendimento da turbina depende diretamente da quantidade de ar introduzido na câmara de combustão. Em altas temperaturas, o ar apresenta baixa densidade e, portanto, a massa de ar fornecido à turbina se reduz. Existem aumentos documentados de até $24 \%$ no rendimento da turbina.

O número de sistemas de resfriamento evaporativo instalados tem aumentado no mundo devido suas vantagens em relação aos sistemas convencionais, pois este sistema tem potencial enorme de utilização, apesar de certas limitações em seu desempenho obrigar a uma análise mais rigorosa.

É sobre essa "análise mais rigorosa" que se baseia a proposta deste trabalho. Desenvolver uma metodologia na elaboração dos projetos de instalação deste tipo de sistema com a aplicabilidade dos conhecimentos trazidos do estudo dos fenômenos de transporte referentes à transferência de massa e quantidade de movimento, para o dimensionamento do 
sistema de evaporação a ser aplicado e de energia térmica na elaboração dos parâmetros e cálculos de projeto de instalação. Estes conceitos vão permitir a aplicação dos sistemas de resfriamento evaporativos com a precaução da eficiência energética, uma vez que relaciona os fenômenos físicos externos que interferem no seu desempenho.

Em relação ao desempenho destes sistemas de resfriamento evaporativo, existe uma classificação de acordo com o tipo de contato que se estabelece entre a água evaporada e o ar a ser resfriado e, também, quanto à energia requerida para promover a evaporação. Os mais utilizados são:

- Resfriamento evaporativo indireto: quando o ar a ser resfriado se mantém separado do processo evaporativo e sem receber umidade.

- Resfriamento evaporativo direto: quando a água evapora em contato com o ar que se deseja resfriar, umidificando-o.

ARBEL et al. (1999) também fazem uma comparação experimental entre o desempenho do sistema pad \& fan (resfriamento evaporativo indireto) e o sistema de spray (resfriamento evaporativo direto), demonstrando as vantagens deste último quanto à homogeneidade de temperatura e umidade, independente das dimensões do ambiente. No sistema pad \& fan o ambiente tem que possuir dimensões apropriadas e limitadas para que não tenha gradiente muito grande de temperatura e umidade, como publicou JAIN E TIWARI (2002).

ARBEL et al. (2003) conduziu experimentos para verificar o desempenho de sistemas de sprays combinados com ventilação forçada. Os resultados demonstraram grande uniformidade horizontal e vertical na distribuição de temperatura e umidade.

O resfriamento evaporativo direto consiste em umidificar diretamente o ar a fim de reduzir sua temperatura para a troca de fase (água no estado líquido para o estado gasoso, ou para vapor de água). A micro aspersão, em especial, será nossa estratégia adotada para o início do estudo que irá determinar um modelo para o dimensionamento deste sistema e uma primeira análise de sua eficiência energética.

Os sistemas de micro aspersão caracterizam-se pela aspersão de gotículas de água tão minúsculas (entre 10 e $20 \mu$ ) que tendem a evaporar completamente e rapidamente quando em 
contato com o ar, retirando calor deste e baixando sua temperatura, sem molhar nem projetar água líquida, embora a névoa seja visível.

A água atomizada evapora na área a ser resfriada e provoca uma redução da temperatura, bastante rápida. A atomização da água é feita através de bomba de pistão que, em alta pressão, que força a saída da água por bicos aspersores de pequeno diâmetro $(0,2$ a 0,5 $\mathrm{mm})$. Estes aspersores, alimentados por tubulações de reduzido diâmetro (de 0,3178 cm a 2,54 cm), são distribuídos pelo ambiente conforme a necessidade de resfriamento.
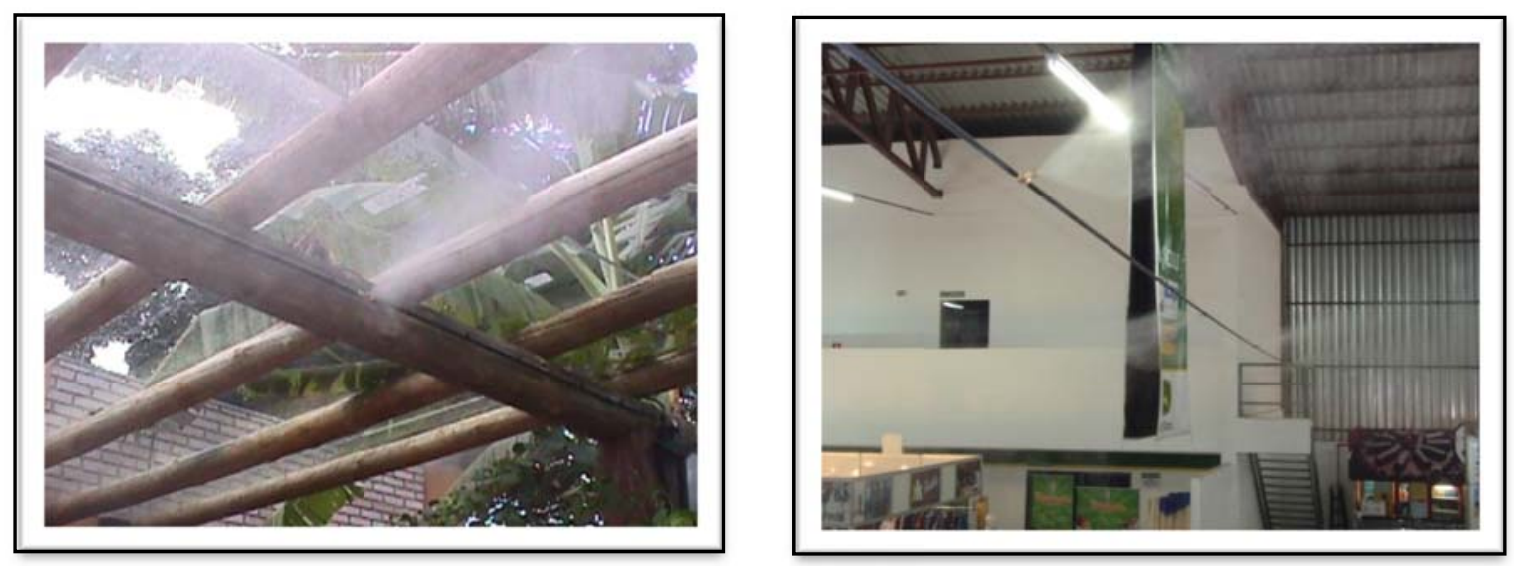

Figura 1.14 - Sistema de micro aspersão - redes de aspersão Fonte: Instalações executadas pelo autor em 2007 - Goiânia - GO

O processo de atomização, mostrado na figura 1.14, ocorre quando um jato ou lâmina de líquido se desintegra devido à energia cinética do próprio líquido, ou por exposição a uma alta velocidade do ar, ou como resultado de uma energia mecânica aplicada externamente através de dispositivos rotacionais ou vibracionais. Devido à natureza randômica do processo de atomização, o spray resultante é usualmente caracterizado por um amplo espectro de tamanhos de gota (LEFEBVRE, 1989).

Independentemente do tipo de atomizador, o principal objetivo dos sprays é incrementar a área superficial do líquido aspergido, e assim, aumentar as taxas de troca de calor e massa da água com o ambiente. O objetivo está em calcular estas trocas de calor e massa, a fim de que seja possível avaliar o desempenho deste processo como sistema de resfriamento evaporativo.

Não molhar é uma condição básica. Normalmente, em estufas de produção de mudas adotam, como opção de controle de umidade, os sistemas de micro aspersão. Estes têm como um dos fundamentos de projeto não molhar as folhagens para que isso não favoreça o 
surgimento de doenças nas plantas. Outro fato que caracteriza essa condição é a utilização de sistemas de micro aspersão no resfriamento de ambientes ocupados por seres humanos e equipamentos, onde o risco de umedecer e as questões referentes à umidade têm maior importância. Assim, não apenas o efeito de resfriamento a partir da evaporação tem importância, mas também o alcance do jato de spray, que por sua vez depende de uma série de fatores, tais como o tamanho das gotas, a velocidade e temperatura destas, o ângulo do jato e as condições internas e externas de temperatura e umidade. Ou seja, é essencial que se conheça o comportamento do spray e as variáveis envolvidas na determinação da sua aplicabilidade.

A princípio, os fatores que influenciam o comportamento deste jato e que se deve considerar são:

- Processo da atomização;

- Caracterização do Spray;

- Penetração e dispersão

- Propriedades termodinâmicas.

O estudo de sprays envolve diversas áreas da engenharia referentes à dinâmica dos fluidos, transferência de calor e massa, atomização. As soluções de sistemas deste tipo incluem a solução de equações de conservação da massa, da energia e da quantidade de movimento.

A evaporação de partículas líquidas está comumente associada a um movimento relativo entre a gota e o ar ambiente. Estes perfis de velocidade têm um grande impacto nas trocas de massa e energia entre o ar e as gotas, que podem ser modeladas em diferentes níveis de complexidade.

Estudar essas trocas em busca de um modelo de dimensionamento que traduza o processo de evaporação do spray voltado para o entendimento das limitações que reduzem as taxas de evaporação, ou seja, que determinem as variáveis que interferem diretamente no desempenho do sistema evaporativo instalado, como por exemplo:

- Variáveis Ambientais:

- Altitude;

- Temperatura do ar exterior;

- Umidade relativa externa. 
- Variáveis de Projeto:

- Área;

- Pé-direito;

- Temperatura inicial do ar interior;

- Umidade relativa inicial interna;

- Taxa de renovação de ar;

- Número de aspersores;

- Carga térmica sensível;

- Carga térmica latente.

- Variáveis de Controle:

- Máxima umidade relativa permitida;

- Mínima umidade relativa permitida;

- Máxima temperatura do ar permitida;

- Mínima temperatura do ar permitida;

- Histerese de umidade;

- Histerese de temperatura.

- Variáveis referentes ao micro aspersor (Spray):

- Ângulo do Spray;

- Vazão do bico;

- Raio das gotas;

- Velocidade de entrada das gotas;

- Temperatura de entrada das gotas. 
Uma extensa pesquisa tem sido conduzida para analisar a influência de fatores tais como o a velocidade do ar úmido, temperatura e umidade relativa, a velocidade e temperatura da água de resfriamento, condução de calor longitudinal, as propriedades de troca de calor e massa do sistema e geometrias da área de resfriamento. Também sobre a eficiência de destes sistemas evaporativos tradicionais e melhorias que podem ser implantadas, buscando aumentar a eficiência destes processos (CHEN, Q. et al, 2010).

O primeiro fato que se deve estar ciente é que os sistemas são projetados para uma determinada capacidade de resfriamento. Segundo Donald et al, 2000, a eficiência padrão de um sistema de resfriamento está em torno de 50\% a 75\%. Com $75 \%$ de eficiência o sistema de resfriamento evaporativo deve conseguir em torno de 12 graus célsius, a nível de sensação térmica, na redução de temperatura. Com $50 \%$ de eficiência o sistema deve produzir um resfriamento em torno de 8 graus.

A fim de considerar todas as variáveis, extensos estudos resultaram no desenvolvimento de softwares específicos e com algumas versões sofisticadas de modelos, incluindo pacotes comerciais, tais como Flow3D e Phoenix, elaborados em códigos de CFD (Computational Fluid Dynamic). Entretanto, a aplicação prática dos modelos requer profundo conhecimento do spray, alguma experiência em programação e cálculo de sistemas com parâmetros distribuídos. Portanto, ainda há uma demanda considerável por modelos simples, que possam ser utilizados para otimizar as decisões do projetista (ZBICINSKI, 1995).

As considerações a se fazer em projeto, para otimizar a transferência de calor, têm sido muitas vezes a chave para uma melhor utilização da energia e estas considerações foram evoluindo e apresentando conceitos bem desenvolvidos nas áreas da física e engenharia. Durante as últimas décadas, um grande número de tecnologias envolvendo o aumento de transferência de calor têm sido aplicadas com êxito não só no consumo de energia, mas também o custo do próprio equipamento.

Recentemente, GUO et al. (2007) introduziram os conceitos de entransy e dissipação entransy para medir, respectivamente, a capacidade e de transferência de calor de um objeto ou um sistema, e a perda dessa capacidade durante um processo de transferência de calor, respectivamente. Além disso, eles desenvolveram a lei resistência térmica mínima com base na dissipação entransy, para a otimização de transferência de calor. Isto é, o mínimo resistência térmica com base na dissipação entransy leva à máxima eficiência da transferência de calor. 
Em princípio todos estes estudos são para maximizar o efeito de refrigeração num sistema de resfriamento evaporativo que tem o ar úmido de entrada de dada capacidade endotérmica, isto é, para minimizar a dissipação da capacidade endotérmica causado pela "inerente resistência à transferência de calor e massa". No entanto, estes mecanismos físicos envolvidos podem não envolver todo processo. Pode haver, ainda, algumas quantidades físicas faltando tanto na estimativa da capacidade endotérmica do ar úmido admitido, quanto na medição da capacidade de dissipação endotérmica durante o processo.

\subsection{Objetivo}

Aumentar a eficiência do sistema de resfriamento evaporativo passa a ser o objetivo desse trabalho, o que compreende estabelecer os limites das variáveis que interferem no processo do resfriamento, ou seja, nos resultados que determinam a condição térmica e na aplicabilidade destes sistemas. Este trabalho não foca o mecanismo de formação do spray, resultante da geometria interna do aspersor, mas especificamente o spray e seu comportamento após formado.

Independentemente do tipo de atomizador, a função do spray é incrementar a área superficial do líquido aspergido assim, melhorar as taxas de troca de calor e massa deste com o ambiente. Sendo assim, o aumento da eficiência do sistema está em estabelecer um maior controle sobre o processo de atomização, na formação da gota e na vazão de saída do spray a fim de que seja possível a alteração desses parâmetros durante o funcionamento do sistema, interferindo, conforme a necessidade, no desempenho deste processo de resfriamento. 


\section{RESFRIAMENTO EVAPORATIVO}

$\mathrm{Na}$ área de resfriamento evaporativo havia uma grande lacuna de avaliação de dados e muitos erros e ineficiências persistiram na confecção, venda e instalação. Estes sistemas ficaram imersos em desinformação e dúvidas. Além disso, houve uma época em que os equipamentos de resfriamento evaporativo indireto foram considerados caros em comparação com linhas semelhantes de condicionadores de ar. No entanto, a necessidade de conservação de energia, o aumento do custo da energia, a preocupação com a qualidade do ar interno e a consciência ambiental no que se refere à emissão de clorofluorcarbono (CFC) reavivaram o interesse pelos sistemas diretos e indiretos de resfriamento evaporativo (WATT e BROWN, 1997).

Os sistemas de micro aspersão, algumas vezes denominados de sistema de atomização, representam um tipo de resfriamento evaporativo direto que é citado por WATT E BROWN, (1997) e também por GIVONI (1994) como alternativa de resfriamento de áreas externas, não configurando entre as técnicas de resfriamento evaporativo de ambientes internos, a não ser áreas de criação de animais e estufas de cultivo de plantas. $\mathrm{O}$ fato de não constar entre as técnicas de resfriamento evaporativo aplicadas em ambientes internos pode ter relação com a utilização de micro aspersores, diretamente aplicados no ambiente, gerar umidades imprevisíveis devido à ausência de alguns parâmetros de controle do processo, comprometendo não só o potencial de resfriamento possível como também o nível que a umidade relativa interna pode alcançar, modificando a eficiência do sistema.

Os sistemas de micro aspersão, mostrados na figura 2.1, caracterizam-se pela aspersão de gotículas de água pequenas o suficiente (entre 10 e $20 \mu$ de diâmetro) para que se evaporem completamente e rapidamente quando em contato com o ar, retirando calor deste e baixando sua temperatura, sem molhar nem projetar água líquida sobre as pessoas próximas, embora a névoa seja visível (GIVONI, 1994), até que a evaporação se complete. Como toda água atomizada evapora na área a ser resfriada a redução da temperatura é bastante rápida. Esta condição de evaporação é conseguida em função das características dos aspersores utilizados e da pressão de trabalho aplicada. 

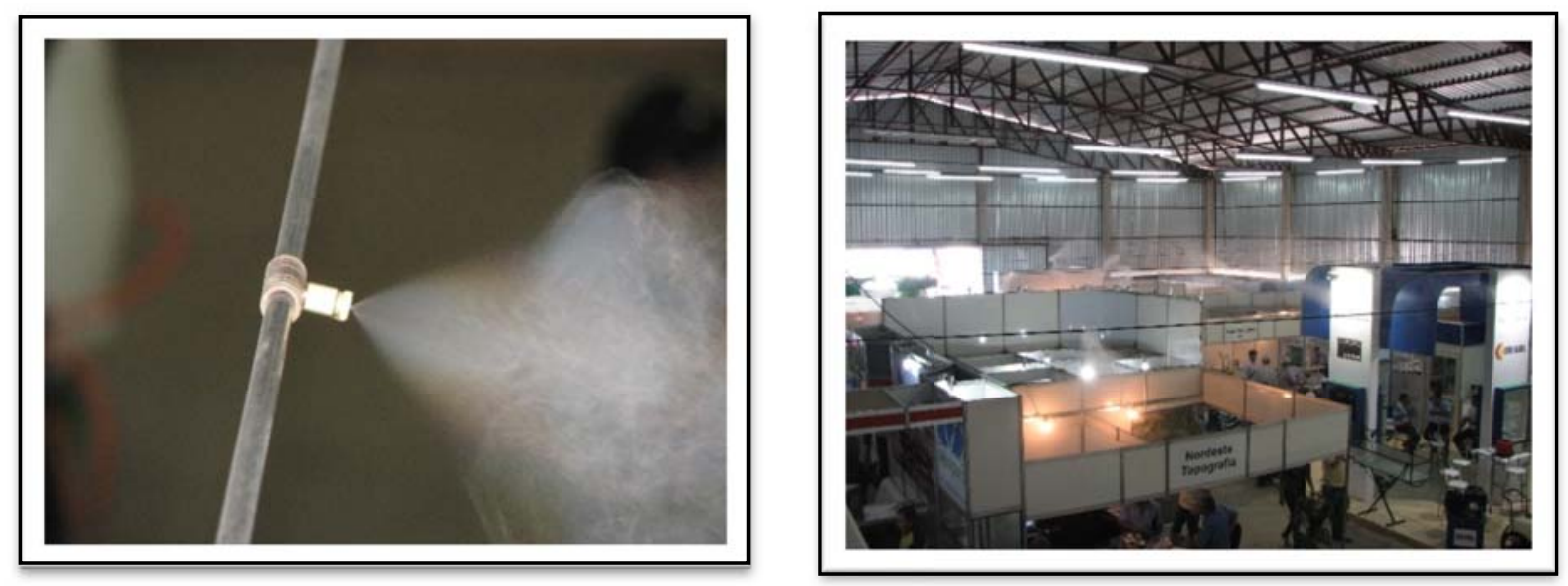

Figura 2.1 - A névoa produzida em uma instalação interna.

Fonte: Instalação executada pelo autor em 2012 - Barreiras - BA

\subsection{Propriedades Termodinâmicas}

O princípio do resfriamento evaporativo consiste em umidificar diretamente o ar a fim de reduzir sua temperatura pela troca de fase (água no estado líquido para o estado gasoso, ou para vapor de água), que ocorre em um processo adiabático, ou seja, não há nenhum ganho ou perda de calor. Portanto, a energia requerida para evaporar a água é suprida pelo ar com consequente aumento da umidade do ar insaturado e queda da temperatura de bulbo seco.

O conhecimento das condições de umidade do ar é um fundamento do processo de resfriamento evaporativo. Mesmo a conservação de produtos tais como frutas, legumes e outros, tem seu sistema de refrigeração dependente de uma mistura apropriada (ar seco/vapor de água). A secagem de grãos, processo fundamental para armazenagem e transporte, é igualmente limitada pelas condições do ar atmosférico.

Por vezes, o índice de conforto térmico de um ambiente depende mais da quantidade de vapor de água presente no ar do quadrante, do que da própria temperatura. O sistema de resfriamento evaporativo, por sua vez, permite muito mais controle das condições de umidade quando comparado a pequenas variações obtidas na temperatura do ambiente. Sendo assim, as determinações de parâmetros específicos relacionados as propriedades da mistura de ar seco e vapor de água ou o ar úmido, propriamente, torna-se um fundamento na determinação do processo. 
Nas instalações de sistemas de resfriamento evaporativo pode-se verificar que o índice de conforto térmico que se é pretendido alcançar no ambiente depende muito mais da quantidade de vapor de água presente na atmosfera do que da temperatura propriamente dita. Dessa forma o estudo psicrométrico, ou seja, conhecer detalhadamente a mistura de ar seco $\left(\mathrm{N}_{2}+\mathrm{O}_{2}+\mathrm{CO}_{2}+\right.$ outros$)$ e o vapor de água ou ar úmido e suas propriedades são condições para análise e determinação desse índice.

As propriedades das misturas de ar seco e de vapor de água e da sua aplicação na análise dos processos de resfriamento evaporativo são básicas tanto para o entendimento das condições ambientais resultantes desse processo quanto das suas limitações. A abordagem dessas propriedades parte da análise em separado envolvendo o ar seco e o vapor de água e, também, das propriedades relacionadas ao ar úmido e processos de tratamento do ar interior em espaços fechados. São elas:

As propriedades do ar seco:

- Massa Constante dos gases do ar seco;

- Volume específico do ar seco;

- Calor específico do ar seco;

- Entalpia do ar seco.

As propriedades do vapor de água:

- Massa Constante dos gases do vapor de água;

- Volume específico do vapor de água;

- Calor específico do vapor de água;

- Entalpia do vapor de água.

As propriedades do ar úmido:

- Lei de Gibbs-Dalton;

- A relação entre as pressões parciais e as temperaturas;

- Entalpia do ar úmido. 


\subsubsection{Propriedades do ar seco}

$\mathrm{O}$ ar seco é uma mistura de gases onde predominam o azoto (N2) e o oxigénio (O2). A composição do ar seco é ligeiramente variável com a localização geográficia. Por essa razão utiliza-se normalmente no estudo do ar seco, uma mistura de composição fixa, designada por "ar padrão". A tabela 2.1, abaixo, mostra os parâmetros específicos relacionados a composição do ar padrão:

Tabela 2.1 - Composição do ar seco ao nível do mar

\begin{tabular}{ccc}
\hline \multicolumn{1}{c}{ Gas } & $\% /$ volume \\
\hline Nitrogênio & $\mathrm{N}_{2}$ & 78,084 \\
Oxigênio & $\mathrm{O}_{2}$ & 20,948 \\
Argônio & $\mathrm{Ar}$ & 0,934 \\
Dióxido de carbono & $\mathrm{CO}_{2}$ & $0,033^{*}$ \\
Neônio & $\mathrm{Ne}^{*}$ & 0,00182 \\
Hidrogênio & $\mathrm{H}_{2}$ & 0,0010 \\
Hélio & $\mathrm{He}$ & 0,00052 \\
Metano & $\mathrm{CH}_{4}$ & $0,0002^{*}$ \\
Monóxido de carbono & $\mathrm{CO}^{*}$ & $0,00001^{*}$ \\
Ozônio & $\mathrm{O}_{3}$ & $0,000002^{*}$ \\
Amônia & $\mathrm{NH}_{3}$ & 0,000001 \\
Dióxido de nitrogênio & $\mathrm{NO}_{2}$ & $0,0000001^{*}$ \\
Dióxido de enxofre & $\mathrm{SO}_{2}$ & $0,00000002^{*}$ \\
\hline * Gases traço de importância ambiental. \\
Fonte: SILVA et.al, 2004
\end{tabular}

1) Massa constante dos gases do ar seco:

$\mathrm{O}$ ar padrão seco tem uma massa molecular de 28,9645. A constante dos gases do ar seco:

$$
R_{a}=\frac{8314,41}{28,9645}=287,055 m^{3} \cdot P_{a} /(K g \cdot K)
$$

2) Volume específico do ar seco:

O volume específico é o volume ocupado por uma unidade de massa $\left(\mathrm{m}^{3} / \mathrm{Kg}\right)$. O volume específico do ar seco pode ser derivado da lei dos gases ideais e é dado pela equação: 


$$
V^{\prime}{ }_{a}=\frac{R_{a} T_{A}}{P_{a}}
$$

3) Calor específico do ar seco:

Sendo o calor específico a pressão constante $\left(c_{p}\right)$ a quantidade de calor necessário fornecer a uma unidade de massa para aumentar a temperatura em $1{ }^{\circ} \mathrm{C}$ a pressão constante, temos:

- O calor específico do ar seco à pressão de $1 \mathrm{~atm}$. (101,325 $\mathrm{kPa})$, num intervalo de temperaturas entre -40 e $60^{\circ} \mathrm{C}$ varia entre 0,997 e $1,022 \mathrm{kj} /(\mathrm{kg} . \mathrm{K})$

- Entre 0 e $30^{\circ} \mathrm{C}$ o valor aproximado de $c_{p}$ é $1,005 \mathrm{kj} /(\mathrm{kg} . \mathrm{K})$

Um valor de $c_{p}=1,01 \mathrm{kj} /(\mathrm{kg} . \mathrm{K})$ ou mesmo $c_{p}=1,0 \mathrm{kj} /(\mathrm{kg} . \mathrm{K})$ pode ser utilizado na maior parte dos cálculos para temperatura entre -10 e $100^{\circ} \mathrm{C}$.

A tabela 2.2, a seguir, relaciona o calor específico com aas faixas de temperaturas consideradas.

Tabela 2.2 - Calor específico do ar seco

\begin{tabular}{cc}
\hline $\begin{array}{c}\text { Temperatura } \\
\text { ( } \mathrm{C})\end{array}$ & $\begin{array}{c}\text { Calor especifico do ar seco } \\
\left(\mathrm{kJ.kg}^{-1} \mathrm{~K}^{-1}\right)\end{array}$ \\
\hline-20 & 1,005 \\
0 & 1,011 \\
10 & 1,010 \\
20 & 1,012 \\
30 & 1,013 \\
\hline
\end{tabular}

Fonte: SINGH E HELDMAN, 2001

4) Entalpia do ar seco:

A entalpia $(\mathrm{H})$ é uma propriedade termodinâmica definida como a soma da energia interna de um sistema (U) e do produto entre a pressão (p) e o volume (V) do sistema:

$$
H=U+p V
$$

A entalpia tem de ser definida em relação a um ponto de referência. Em psicrometria, a pressão de referência é a pressão atmosférica $(101,325 \mathrm{kPa})$ e a temperatura de referência é $0^{\circ} \mathrm{C}$. A entalpia calcula-se multiplicando o calor específico do ar seco pela diferença entre a temperatura do ar e a temperatura de referência $\left(0^{\circ} \mathrm{C}\right)$.

$$
H_{a}=c_{p}\left(T_{a}-T_{0}\right)
$$


Como a temperatura de referência é $0{ }^{\circ} \mathrm{C}$ e $C_{p}$ do ar seco é aproximadamente igual entalpia do ar seco é sensivelmente equivalente à temperatura do $\operatorname{ar}\left(\mathrm{em}^{\circ} \mathrm{C}\right)$.

$$
H_{a}=1,005 T_{a}
$$

A temperatura do bulbo seco (T) é a temperatura do ar medida com um termómetro ordinário, designada assim para se distinguir da temperatura do termómetro de bulbo húmido.

\subsubsection{Propriedades do vapor de água}

A característica do vapor de água que nos remete a consideração é o fato de carregar, relativamente, grandes quantidades de energia por unidade de massa.

1) Massa e constante dos gases do vapor de água

A água tem uma massa molecular de 18,01534. A constante dos gases do vapor de água é:

$$
R_{v}=\frac{8314,41}{18,01534}=461,52 m^{3} \cdot P a /(K g \cdot K)
$$

2) Volume específico do vapor de água

A temperaturas inferiores a $66{ }^{\circ} \mathrm{C}$ o vapor de água segue aproximadamente a lei dos gases ideais. O volume específico do vapor de água é:

$$
V_{v}^{\prime}=\frac{R_{v} T_{A}}{P_{v}}
$$

3) Calor específico do vapor de água

O calor específico do vapor de água varia pouco entre -71 e $124{ }^{\circ} \mathrm{C}$, podendo-se considerar o valor $C_{p}=1,88 \mathrm{kj} /(\mathrm{kg} . \mathrm{K})$. No âmbito deste trabalho consideraremos o valor $C_{p}=$ $1,86 \mathrm{kj} /(\mathrm{kg} \cdot \mathrm{K})$. 
4) Entalpia do vapor de água

A entalpia do vapor de água é dada pela expressão:

$$
H_{v}=2501,4+1,86\left(T_{a}-T_{0}\right)
$$

Quanto ao calor latente de vaporização $L_{v}$ da água, este varia com a temperatura vale $2501,4 \mathrm{~kJ} / \mathrm{kg}$. Pode ser calculado no intervalo de temperaturas entre 0 e $200^{\circ} \mathrm{C}$ com uma precisão de cerca de $0,02 \%$ pela fórmula empírica de Regnault:

$$
L_{v}=2538,02+2,91 T
$$

Sendo $2501,4 \mathrm{~kJ} / \mathrm{kg}$ o valor do calor latente de vaporização a $0,01^{\circ} \mathrm{C}$ e 1,86 o calor específico do vapor de água. A tabela 2.3 relaciona as propriedades do vapor de água saturado.

Tabela 2.3 - Propriedades do vapor da água saturado

\begin{tabular}{cccc}
$\begin{array}{c}\text { Temperatura } \\
(\mathrm{K})\end{array}$ & $\begin{array}{c}\text { Volume especifico } \\
\left(\mathrm{m}^{3} \cdot \mathrm{kg}^{-1}\right)\end{array}$ & $\begin{array}{c}\text { Entalpia } \\
\left(\mathrm{kJ}_{\mathrm{kg}}^{-1}\right)\end{array}$ & $\begin{array}{c}\text { Calor especíico } \\
\left(\mathrm{kJ}_{\mathrm{kg}}^{-1} \cdot \mathrm{K}^{-1}\right)\end{array}$ \\
\hline 0 & 206,3 & 2502 & 1,854 \\
275 & 181,7 & 2505 & 1,855 \\
280 & 130,4 & 2514 & 1,858 \\
285 & 99,4 & 2523 & 1,861 \\
290 & 69,7 & 2532 & 1,864
\end{tabular}

Fonte: PERRY et al., 1998

\subsubsection{Propriedades do ar úmido}

O ar úmido é considerado uma mistura de dois componentes: ar seco e vapor de água. No ar úmido o vapor de água comporta-se como um gás perfeito. Embora a mistura de ar seco e água não siga rigorosamente a lei dos gases ideais, ainda assim é uma boa aproximação do comportamento do ar úmido a pressões inferiores a $3 \mathrm{~atm}$.

1) Lei de Gibbs-Dalton

A quantidade de água, no estado gasoso, presente na atmosfera é limitada para cada valor de temperatura. A pressão do ar úmido (pressão barométrica) é, de acordo com a lei de Gibbs-Dalton, a soma das pressões parciais exercidas pelo ar seco e pelo vapor de água contido na atmosfera. 


$$
P_{B}=P_{a}+P_{v}
$$

2) A relação entre as pressões parciais e as temperaturas

Por se tratar de uma mistura binária de ar seco com vapor de água. A quantidade de água no ar úmido varia de zero (ar seco) até um máximo que depende da temperatura e da pressão. A última condição é denominada de saturação e corresponde a um estado de equilíbrio entre o ar úmido e a água em estado condensado (líquido ou sólido). Com isso é possível estabelecer a relação entre as pressões parciais e as temperaturas das misturas de ar seco e vapor de água é dada pela equação:

$$
P_{v}=P_{w b}-\frac{\left(P_{b}-P_{w b}\right)-\left(T_{a}-T_{v}\right)}{1555,56-0,722 T_{v}}
$$

As propriedades psicrométricas relevantes ao processo de resfriamento evaporativo são aquelas que relacionam o ar úmido, ou seja, a mistura de ar seco e vapor de água, e o processo de umidificação e resfriamento com a mudança da temperatura ou da quantidade de vapor de água na mistura.

3) Entalpia do ar úmido

A entalpia do ar úmido pode ser calculada através destas expressões, utilizando valores do calor latente de vaporização da água e dos calores específicos a pressão constante do ar seco e do vapor de água.

$$
H=1,01 T+W(2463+1,88 T)
$$

Em que $1,01 \mathrm{kj} /(\mathrm{kg} . \mathrm{K})$ é o calor específico do ar seco, $2463 \mathrm{kj} / \mathrm{kg}$ é o calor latente de vaporização da água e $1,88 \mathrm{kj} /(\mathrm{kg} . \mathrm{K})$ é o calor específico do vapor a pressão constante. 


\subsection{Propriedades Psicrométricas Relevantes no Processo de Resfriamento Evaporativo}

As propriedades que precisam estar fixadas são aquelas que interferem diretamente no processo de evaporação e, colocado dessa forma, são aquelas relacionadas a temperatura, a umidade do quadrante, ao volume ocupado e a energia passível de ser removida na forma de calor (entalpia).

As propriedades relacionadas a temperatura que devem ser fixadas são:

- Temperatura do bulbo seco;

- Temperatura do ponto de orvalho;

- Temperatura do bulbo úmido.

As propriedades relacionadas a umidade do quadrante tem como base:

- Umidade relativa;

- Umidade absoluta;

- Massa de vapor de água (relação de mistura e saturação).

As propriedades relacionadas ao volume ocupado e energia, são:

- Volume específico;

- Entalpia.

A eficiência da queda de temperatura que se pode atingir em um sistema de resfriamento evaporativo é tratada aqui como a relação entre a queda da temperatura do bulbo seco produzida pelo sistema e a temperatura que se atingiria no bulbo seco, sendo o ar de saída, saturado, ou seja a temperatura do ar de saída sendo igual temperatura do bulbo úmido do ar admitido. O comparativo com o sistema de resfriamento ideal teria a temperatura do bulbo seco e o ponto de orvalho igual a temperatura do bulbo úmido (TRANE, 1978). Essa condição deixa claro que estes sistemas tem uma limitação a ser observada, ou seja, quanto maior a umidade relativa do ar de admitido menor será queda de temperatura do processo evaporativo.

As relações psicrométricas são representadas graficamente em diagramas, que permitem analisar a variação de energia envolvida na mudança das características físicas do ar 
úmido. $\mathrm{O}$ cálculo de seus parâmetros, se pode fazer analiticamente mediante as equações que os relacionam e, esses ábacos, são construídos a partir de dessas equações. Na prática se utiliza a carta psicrométrica, não pela sua precisão, mas por oferecer um resultado visual da transformação.

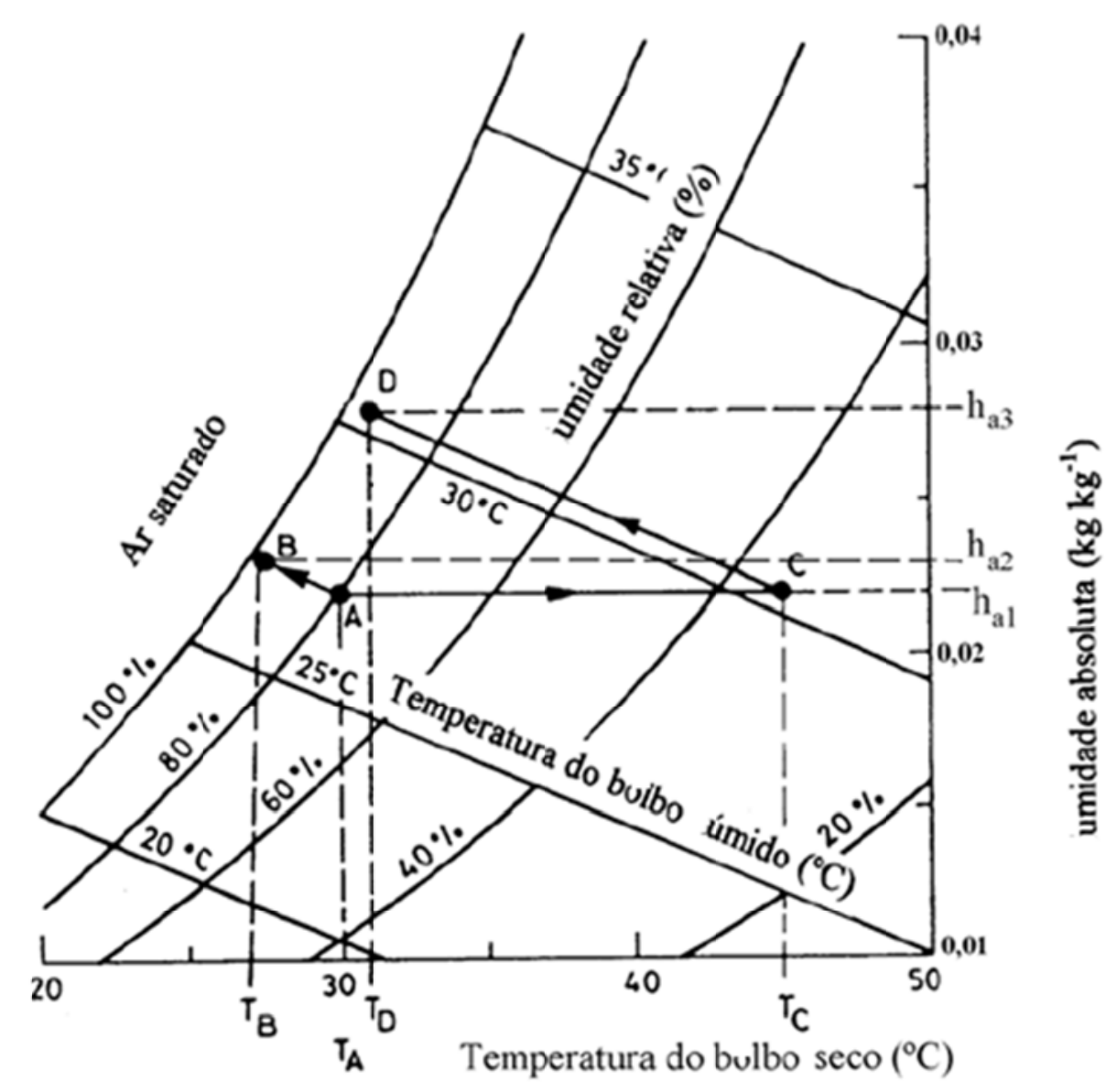

Figura 2.2 - Representação esquemática do diagrama psicométrico Fonte: ONOFRE, 1996

\subsubsection{As propriedades relacionadas à temperatura}

1) A temperatura do bulbo seco $(T)$

Temperatura do bulbo seco é a temperatura do ar medida com um termómetro ordinário, e não é influenciada pela humidade relativa do ar. 
2) Temperatura do ponto de orvalho $\left(T_{p o}\right)$

Temperatura em que a pressão parcial de vapor de água é igual à pressão de vapor saturante. Mede-se com um higrómetro de ponto de orvalho. A temperatura do ponto de orvalho pode ser calcula através das expressões:

$$
\begin{aligned}
& T_{p o}=\frac{27,952 \times \log \left(\frac{P_{v}}{613,34}\right)}{1-0,1025 \times \log \left(\frac{P_{v}}{613,34}\right)} \text { se } T_{p o}<0^{\circ} \mathrm{C} \\
& T_{p o}=\frac{27,952 \times \log \left(\frac{P_{v}}{613,34}\right)}{1-0,1311 \times \log \left(\frac{P_{v}}{613,34}\right)} \text { se } T_{p o}>0^{\circ} \mathrm{C}
\end{aligned}
$$

3) Temperatura de bulbo úmido $\left(T_{m}\right)$

Temperatura do bulbo úmido é a temperatura mais baixa que pode atingir o ar úmido quando é resfriado apenas devido à evaporação de água. A temperatura do termómetro de bulbo úmido é geralmente inferior à temperatura do termómetro de bulbo seco, exceto quando o ar está saturado; neste caso as duas temperaturas são iguais. Quanto mais seco estiver o ar, maior é a diferença entre $T_{m} e T$, sendo $T_{m} \leq T$

A temperatura do bulbo úmido mede-se com uma termómetro cujo bulbo está coberto de pôr uma mecha saturada de água pela qual passa uma corrente de ar para favorecer a evaporação da água.

\subsubsection{Propriedades relacionadas à umidade}

1) Umidade absoluta $(W)$

A umidade absoluta, é definida como a massa de vapor de água por unidade de volume, ou seja, a densidade do vapor de água.

$$
W=\frac{m_{v}}{V}
$$


Como variações na pressão e temperatura podem alterar o volume, tais variações podem alterar a umidade absoluta sem que vapor de água seja adicionado ou removido. Consequentemente, é difícil descrever o conteúdo de vapor de água de uma massa de ar móvel se usarmos o índice umidade absoluta. Portanto, nas determinações das características psicrométricas para o estudo dos sistemas de resfriamento evaporativo o índice mais usado é a razão de mistura para definir a umidade absoluta de uma amostra de ar úmido que é a massa de vapor de água (gramas) por unidade de massa de ar seco (quilogramas) ou umidade específica $(w)$, por massa total (ar seco mais vapor de água).

$$
w=\frac{m_{v}}{m_{a}}
$$

A razão entre as frações molares de vapor de água e ar seco, $x_{v} / x_{a}$, multiplicado pelas massas moleculares, temos:

$$
\begin{gathered}
W=\left(\frac{18,01534}{28,9645}\right) \frac{x_{v}}{x_{a}}=0,622 \frac{x_{v}}{x_{a}} \rightarrow W=0,622 \frac{P_{v}}{P_{a}}, \operatorname{como} P_{B}=P_{a}+P_{v} \\
W=0,622 \frac{P_{v}}{P_{B}-P_{v}}
\end{gathered}
$$

A pressão parcial de vapor relaciona-se com a umidade absoluta, considerando que o vapor de água se comporta como um gás perfeito, da seguinte forma:

$$
P_{v}=\frac{W \cdot 101,325}{0,622}
$$

2) Umidade relativa $(\varnothing)$

A umidade do ar é o elemento atmosférico que exerce maior influência sobre a temperatura e a sensação térmica, fatores de fundamento do desempenho dos sistemas de resfriamento evaporativo. Em termos quantitativos, podemos definir a umidade relativa como a razão entre a quantidade de vapor de água presente naquela porção da atmosfera e a quantidade máxima de vapor de água que a atmosfera pode suportar naquela determinada temperatura. Dessa forma a podemos entender que a pressão de vapor é parte da pressão atmosférica total devido ao seu conteúdo de vapor de água e é diretamente proporcional à concentração de vapor no ar. Quanto o ar contém o máximo de vapor, para uma dada 
temperatura, atingimos o ponto de saturação ou ponto de orvalho. Nesse ponto, especificamente, temos máxima pressão de vapor ou a pressão de vapor de saturação $\left(P_{S}\right)$.

Quando a pressão de vapor está abaixo desse limite temos a pressão parcial de vapor para aquela condição atmosférica, específica $\left(P_{v}\right)$. A Relação da pressão parcial de vapor e a pressão de vapor de saturação nos dá a umidade relativa.

$$
\emptyset=\frac{P_{v}}{P_{s}} * 100
$$

$\mathrm{Na}$ gama de temperaturas e de umidades normalmente encontradas nas medições realizadas junto aos equipamentos instalados, podemos estabelecer uma variação da temperatura e da umidade relativa entre $-7^{\circ} \mathrm{C} \leq T \leq 60^{\circ} \mathrm{C}$ e $30 \% \leq \emptyset \leq 70 \%$. Pode ser aplicada uma formula empírica, onde a relação da umidade relativa e a temperatura pode ser calculada por:

$$
\emptyset=1-3\left(\frac{T-T_{m}}{T+18}\right) * 100
$$

\subsubsection{As propriedades relacionadas ao volume ocupado e energia}

1) Volume específico

É o volume ocupado pela mistura de ar seco e de vapor de água contida em $1 \mathrm{~kg}$ de ar seco à pressão de $1 \mathrm{~atm}$. $(101,325 \mathrm{kPa})$. O volume específico $\left(\mathrm{m}^{3} / \mathrm{kg}\right)$ do ar úmido é dado pela relação:

$$
\begin{gathered}
V^{\prime}=\frac{V}{1+W} \\
V^{\prime}=\left(0,082 T_{a}+22,4\right) *\left(\frac{1}{29}+\frac{W}{18}\right)
\end{gathered}
$$

\section{2) Entalpia}

Todo processo do resfriamento evaporativo, o ar permanece com seu valor de entalpia constante. A energia necessária para evaporar a água é retirada do ar sob a forma de calor sensível. Esse calor é transferido do fluido de maior temperatura, no caso o ar, para o de menor temperatura, o que provoca a queda da temperatura do ar e, em seguida, convertido em calor latente, responsável pela mudança de estado da agua de liquido para vapor. Esta conversão de calor sensível ao calor latente é um processo adiabático porque não há nenhum 
ganho ou perda de calor. Sendo assim, o processo de resfriamento evaporativo provoca uma queda na temperatura do ar proporcional à queda de calor sensível e um aumento da umidade proporcional ao ganho de calor latente.

Como o ar úmido é uma mistura de ar seco e de vapor de água, o calor específico da mistura é a soma dos calores específicos dos componentes da mistura. Sempre que as transformações tenham lugar a pressão constante, a quantidade de calor que é necessário fornecer ao ar úmido para elevar a sua temperatura a pressão constante é igual à entalpia específica do ar. Admitindo que a entalpia é nula à temperatura de $0{ }^{\circ} \mathrm{C}$, para o ar à temperatura $T$, teremos:

$$
H+H_{a}+W H_{v}
$$

Se considerarmos que:

$$
\begin{gathered}
H_{a}=C_{p_{a}} * T \mathrm{e} \\
H_{v}=L_{v}+c_{p_{v}} * T, \text { teremos: } \\
H=c_{p_{v}} * T+W\left(L_{v}+c_{p_{v}} x T\right)
\end{gathered}
$$

Estas expressões mostram que a entalpia do ar úmido se compõe nos seguintes termos:

$$
\begin{gathered}
\text { Entalpia do ar seco } \\
\text { Entalpia de evaporação a temperatura do ponto de orvalho } \\
\text { Entalpia adicionada ao vapor de água após a evaporação }
\end{gathered}
$$

Se existirem gotículas de água em suspensão no ar, é ainda necessário adicionar o termo que reflete a entalpia da água à temperatura do ponto de orvalho $\left(m_{\mathrm{H}_{2} \mathrm{O}} * 4,186 * T\right)$.

O diagrama psicrométrico da figura 2.3, a seguir, refere-se a entalpia do ar saturado. Para determinar a entalpia do ar úmido, com uma umidade relativa inferior a $100 \%$ é necessário subtrair o fator de correção, normalmente pequeno, representado nas linhas curvas que sobem a partir do eixo da temperatura do bulbo seco. 


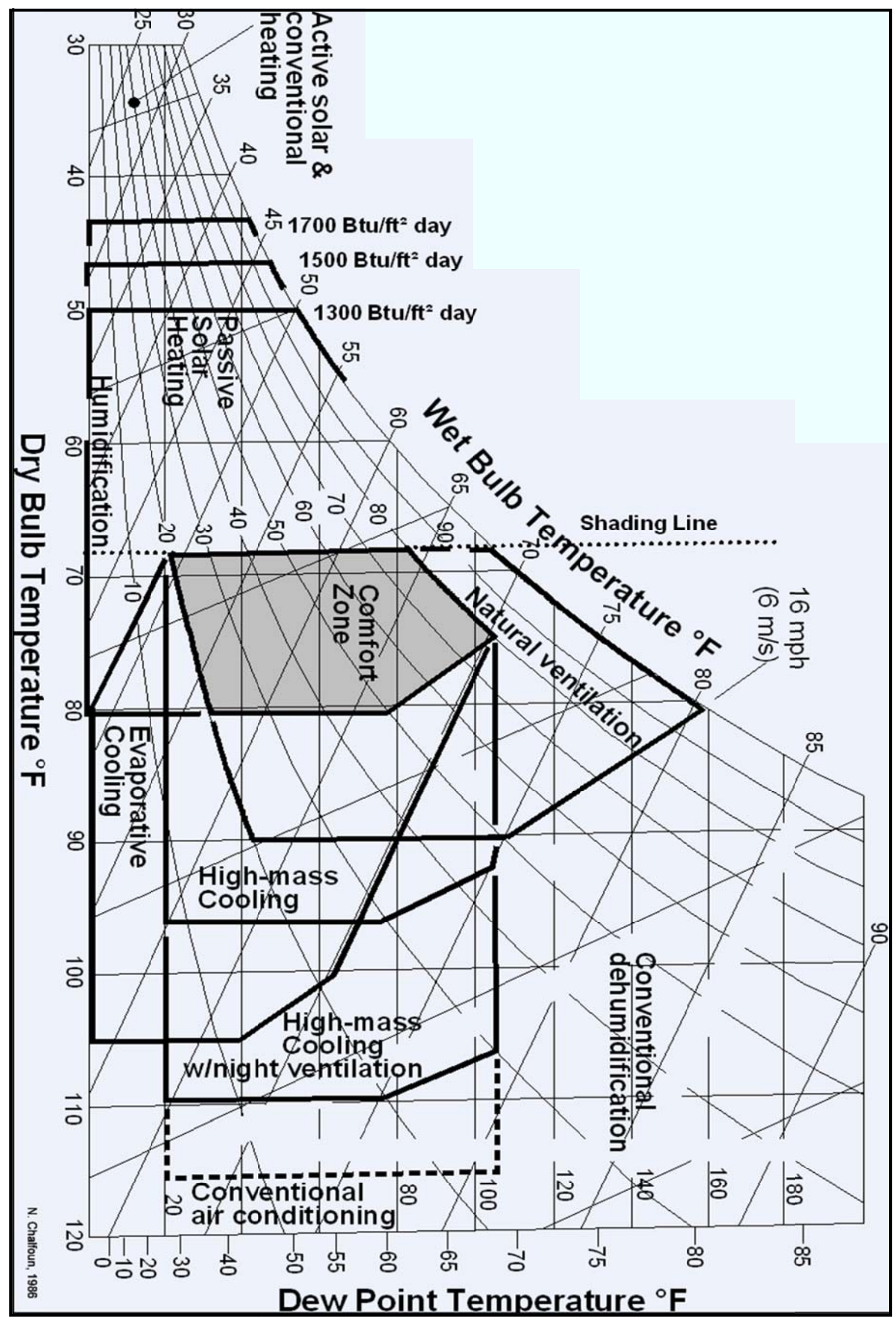

Figura 2.3 - Diagrama psicrométrico_destacando a zona de conforto térmico Fonte: http://capla.arizona.edu/hed/charts.php 


\subsection{Operações que Modificam o Ar}

Nos diversos ramos da atividade industrial ou nas áreas de pré-processamento, transformação, ou ainda, conservação de produtos, a utilização do ar modificado tem sido, cada vez mais, uma necessidade. Em alguns processos, a modificação das características do ar aumenta, por exemplo, o potencial de retenção de umidade fazendo com que se consiga obter resultados que que aceleram o próprio processo, aumentam vida útil do produto final ou ainda garantem algumas condições de manuseio e conservação.

A base para a compreensão de qualquer operação que altera as características do ar e, também, de qualquer sistema de resfriamento evaporativo é a psicrometria. É esta ciência que trata das interações entre ar, calor e umidade. Basicamente o estudo de misturas ar e água é elemento essencial para a compreensão do que faz as características do o ar mudar de uma condição para outra. Quando a temperatura do ar sobe, a sua capacidade para manter a umidade sobe também e o ar mais quente torna-se menos denso. Isso faz da umidade um fator muito influente para o ganho de calor, tanto para as condições de conforto térmico, como para se estabelecer as condições operacionais para modificar as características do ar.

O conhecimento de sistemas, compreendendo ar seco e vapor de água é essencial para o projeto e análise de aparelhos de ar condicionado, torres de resfriamento e processos industriais que exigem um controle rigoroso do teor de vapor no ar. Umidade do ar, calor e a forma como essas interações ocorrem são bastante complexas, como mostrado. Felizmente, essas interações puderam em ser combinadas em um único gráfico (a carta psicrométrica). No entanto, antes de explicar os detalhes de como a carta psicrométrica pode indicar essas interações, cabe introduzir alguns termos, definições e princípios, utilizadas no estudo de sistemas constituídos por ar seco e água.

\subsection{Operações Elementares}

\subsubsection{Variação do calor sensível}

No processo de aquecimento ou resfriamento sensível, a temperatura do ar muda de um ponto para outro, mantendo relação de umidade absoluta constante. A temperatura do bulbo seco é reduzida sem que haja variação da umidade absoluta, uma vez que a temperatura do bulbo úmido é, também, reduzida. Na carta psicrométrica essa relação está representada nos deslocamentos horizontais. 


\subsubsection{Variação do calor latente}

No caso de variação do calor latente a temperatura do bulbo seco que permanece constante, variando a umidade absoluta. No processo de resfriamento ocorre a umidificação do ar sem variação do calor sensível. O calor absorvido é utilizado para evaporar mais água e, como o calor latente de vaporização da água é elevado $(2496 \mathrm{~kJ} / \mathrm{kg})$, o ar tem que absorver calor que é utilizado para evaporar a água, aumentando a umidade absoluta sem que haja variações de temperatura do bulbo seco.

\subsubsection{Variações simultâneas de calor sensível e calor latente}

Nestes processos ocorrem variações simultâneas da temperatura (calor sensível) e da umidade absoluta (calor latente), ou seja, resfriamento com umidificação. Designa -se este processo por saturação adiabática (entalpia constante), pois não há trocas de calor por condução ou por radiação.

No processo de resfriamento evaporativo, as mudanças de temperatura e umidade do ar é observada ao longo das linhas de temperatura do bulbo úmido constante (Carta Psicrométrica). Neste processo ocorrem alterações na temperatura de bulbo seco, volume específico, na umidade relativa, nas relações de umidade, temperatura do ponto de orvalho, e a pressão de vapor do ar úmido. Nenhuma mudança ocorre na entalpia.

\subsubsection{Resfriamento do ar úmido}

No resfriamento do ar úmido devemos considerar 2 comparativos de temperatura, sendo:

- A temperatura de aquele que iremos considerar como "evaporador" ser superior a temperatura do ponto de orvalho do ar que troca calor com o "evaporador". Neste caso, a diferença entre as pressões parciais do vapor da água na superfície fria e no ar é positiva $\left(P_{S_{\text {evaporador }}}>P_{v_{a r}}\right)$ e a superfície do evaporador permaneceria seca, ou seja, o resfriamento ocorreria sem a condensação de vapor. 
- A temperatura daquele que consideramos como "evaporador" ser inferior à temperatura do ponto de orvalho do ar que troca calor no "evaporador". Neste caso a pressão parcial do vapor de água saturado na superfície fria é inferior à pressão parcial de vapor do ar $\left(P_{S_{\text {evaporador }}}<P_{v_{a r}}\right)$, a diferença é negativa. $\mathrm{O}$ resfriamento se dá pela condensação do vapor de água. No final do processo de resfriamento, a umidade absoluta do ar é inferior ao valo inicial $\left(W_{f}<W_{i}\right)$.

\subsubsection{Umidificação}

Umidificação é a transferência de vapor de água para o ar atmosférico. Nesta transferência estão envolvidos fenómenos de transferência de massa e de calor. $\mathrm{O}$ ar é umidificado por meio de pulverizadores ou nebulizadores que reduzem a água a pequenas gotículas que aumentam a superfície de contato entre a água e o ar e favorecem a evaporação. A evolução do ar se faz, seguindo a carta psicrométrica, pela linha reta oblíqua (umidificação adiabática do ar) que corresponde a entalpia constante, vide figura 2.4.

A quantidade de calor latente requerida nesse processo de umidificação pode ser calculada através da relação:

$$
q=H_{f v} * \dot{\mathrm{m}}_{H_{2} O}
$$

onde $q$ é o calor latente adicionado $(W), H_{f v}$ é a entalpia de vaporização da água $(J /$ $\mathrm{kg})$ e $\dot{\mathrm{m}}_{\mathrm{H}_{2} \mathrm{O}}$ é a taxa de vaporização da água $(\mathrm{kg} / \mathrm{s})$.

As trocas térmicas entre o ar e água ocorrem de acordo com a seguinte relação:

$$
\dot{\mathrm{m}}_{a} W d H=\dot{\mathrm{m}}_{H_{2} O} W d T
$$

$\dot{\mathrm{m}}_{a}$ e $\dot{\mathrm{m}}_{\mathrm{H}_{2} \mathrm{O}}$ é o a vazão mássica do ar e da água, $d H$ é a variação da entalpia do ar durante a transformação e $d T$ é a variação da temperatura da água durante a transformação. A equação mostra que o calor perdido pelo ar é igual ao calor ganho pela água. Os nebulizadores pulverizam água em excesso, sendo o excesso recolhido e bombeado novamente para os pulverizadores. 


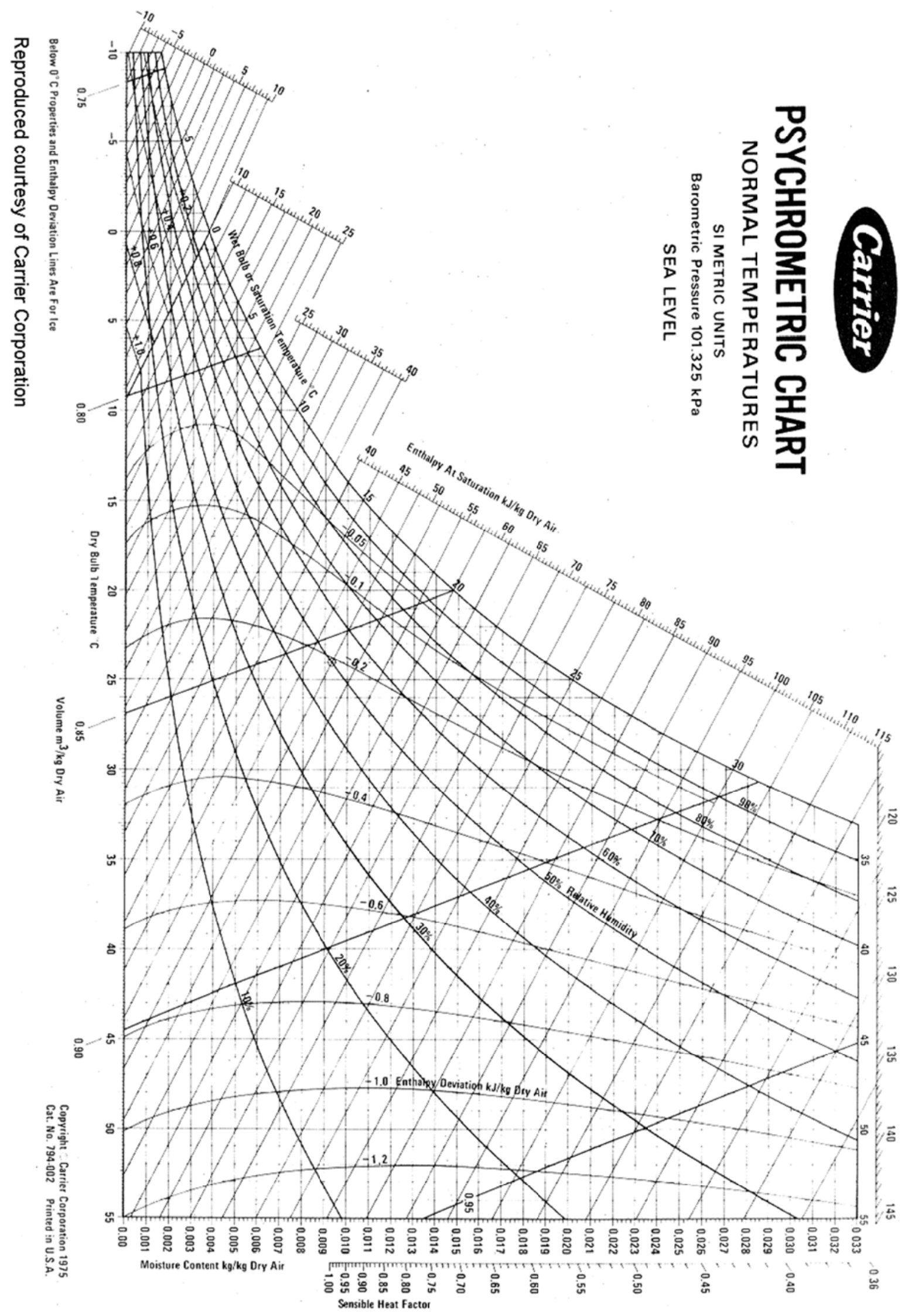

Figura 2.4 - Diagrama Psicrométrico das condições sob pressão atmosférica Fonte: CLARK, 1995 


\subsection{Princípios do Resfriamento Evaporativo}

Independente do processo, se natural ou forçado, se direto ou indireto, o resfriamento evaporativo tem como princípio a evaporação da água e a troca de calor sensível por calor latente.

A quantidade de calor absorvida no processo de evaporação da água é muito maior do que qualquer outro modo de transferência de calor em edifícios. Cada grama de água evaporada, sem aporte externo de calor, retira do ar ambiente, cerca de $2,5 \mathrm{~kJ}$.

Quando a água evapora em uma corrente de ar livre sem adição externa de calor, a Temperatura de Bulbo Seco $\left(T_{a}\right)$ do ar é reduzida e seu conteúdo de umidade é elevado, enquanto sua Temperatura Termodinâmica de Bulbo Úmido $\left(T_{m}\right)$ permanece constante. Este processo, representado na figura 2.5, que ocorre sem adição ou extração de calor é denominado adiabático, pois a quantidade total de calor do ar (sensível + latente) permanece constante.

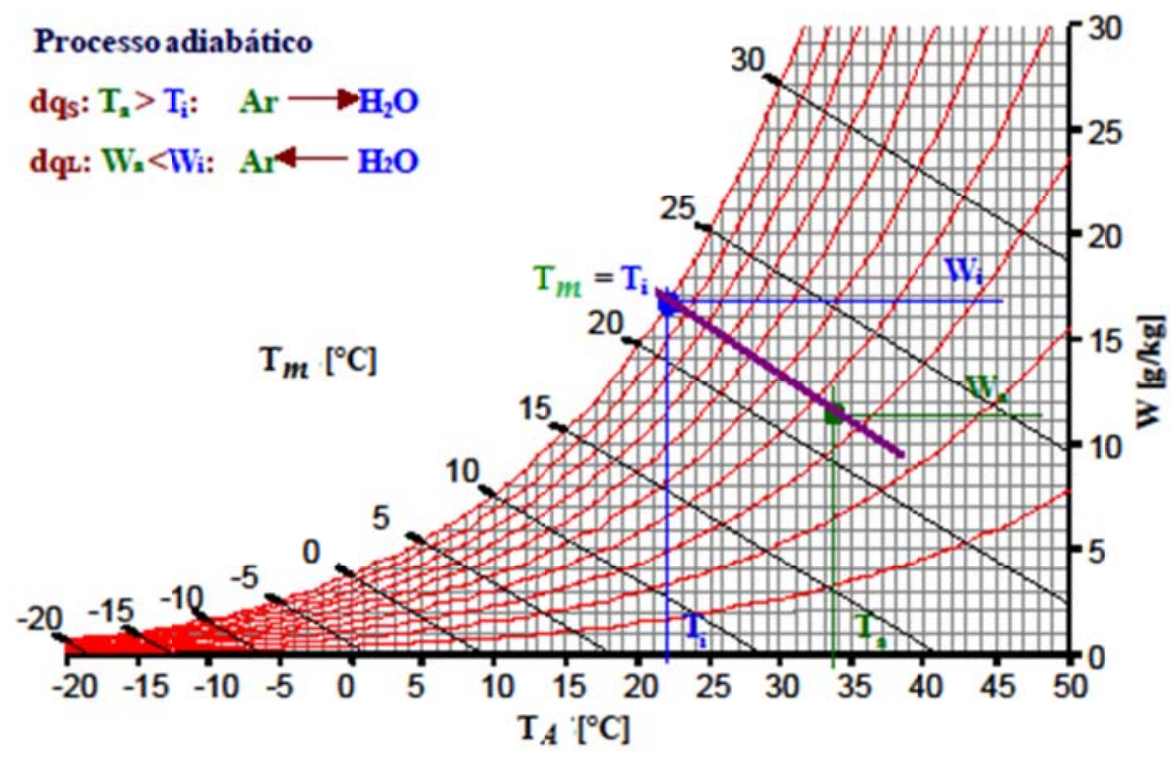

Figura 2.5 - Comportamento adiabático em carta psicrométrica

Fonte: SILVA et. al., 2004

A evaporação do líquido acontece quando suas moléculas próximas à superfície recebem energia, do interior deste líquido, em quantidade superior à necessária para manter as ligações moleculares da fase líquida. Esta energia latente cedida pelo líquido resulta em resfriamento. No entanto, em regime permanente, a energia latente cedida é compensada pela energia transferida da superfície de controle para o líquido. Não considerando os efeitos da 
radiação, o ar da região do contorno transfere a mesma quantidade de energia cedida pelo líquido, uma vez que está em regime permanente. Diz-se, então, que este atingiu a temperatura termodinâmica de bulbo úmido $\left(T_{m}\right)$, mantendo-se constante nesta temperatura. Consequentemente, o calor cedido pelo ar da região de contorno, reduzindo a temperatura e resfriando.

Água e ar entram em equilíbrio termodinâmico na mesma temperatura do bulbo úmido $\left(T_{m}\right)$, considerando que, quando o ar transfere calor e massa (vapor de água) para uma superfície molhada, ou vice-versa, o estado do ar na carta psicrométrica, figura 2.4 , tende para a temperatura de bulbo úmido sobre a linha de saturação (SILVA et. al., 2004).

Em resumo o processo de evaporação depende da:

- Temperatura do ar;

- Umidade relativa do ar;

- Velocidade do ar;

- Temperatura da água;

- Superfície de contato entre a água e o ar.

Nas avaliações teóricas dos sistemas de resfriamento evaporativo, a temperatura da água permanece constante, sem aumentar ou diminuir em contato com o ar. Disso resulta que toda a evaporação serve para resfriar o ar, não para resfriar a água, diminuindo o consumo de água e o ganho de umidade pelo ar. Na prática, entretanto, a água usualmente ganha algum calor sensível no tanque reservatório, na bomba ou na tubulação. Este calor sensível pode ter como fonte o atrito de movimentação, a transferência de calor ambiente e a radiação. Desta forma, a maioria dos "comportamentos adiabáticos" em resfriamento evaporativo representa apenas uma aproximação (WATT e BROWN, 1997).

Quando a temperatura da água está acima da temperatura de bulbo úmido do ar durante o contato inicial, o processo assemelha-se às torres de resfriamento de água quente, onde o ar e água são resfriados. Em contato, ar e água entregam calor sensível e são resfriados pela conversão do calor latente. A água evapora para resfriar tanto a água quanto o ar. Desta forma, mais água é consumida devido à sua temperatura inicial e o ar resfriado é mais quente e úmido do que se a saturação fosse adiabática (WATT e BROWN, 1997).

A carta psicrométrica indica, graficamente, o sentido das trocas de calor sensível $\left(d_{q s}\right)$, calor latente $\left(d_{q l}\right)$ e calor total $\left(d_{q T}\right)$, as quais são determinadas pelas 
propriedades físicas do ar e da água. Podemos representar essas trocas pelos diagramas constantes nas figuras $2.6 ; 2.7 ; 2.8$ :

1) Transferência de calor total do ar para água

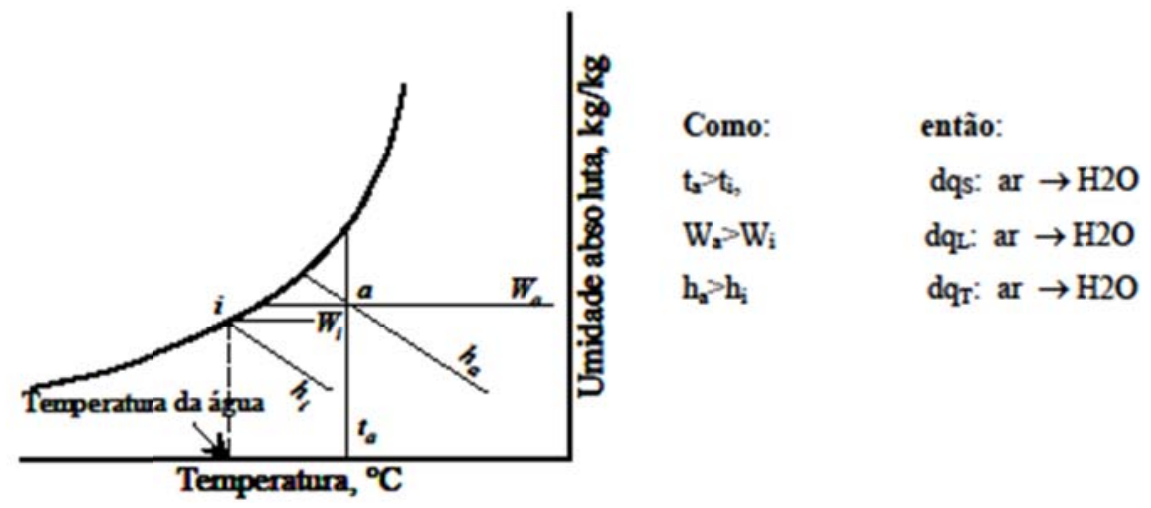

Figura 2.6 - Transferência de calor total do ar para água Fonte: STOECKER e JONES, 1985

2) Transferência de calor latente da água para o ar

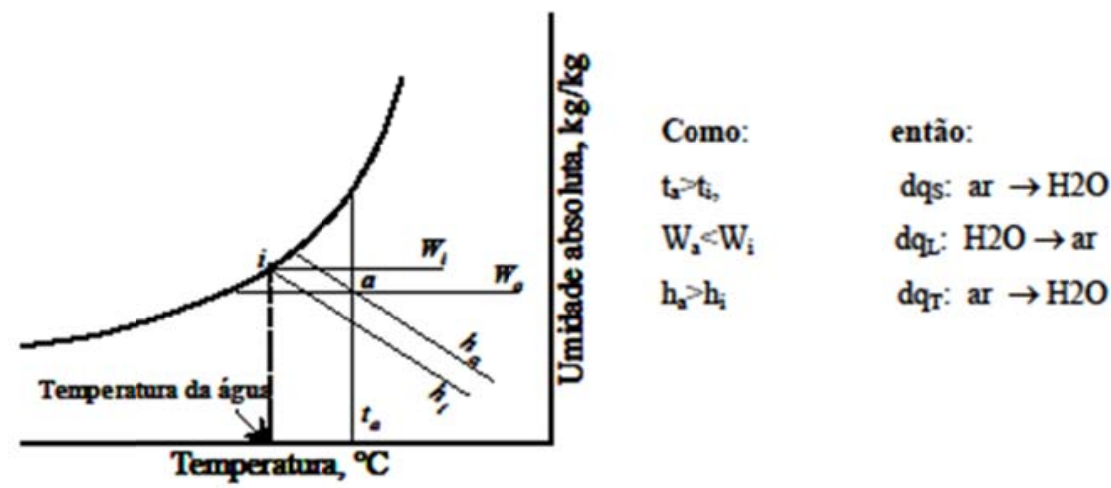

Figura 2.7- Transferência de calor latente da água para o ar Fonte: STOECKER e JONES, 1985

3) Transferência de calor total da água para o ar

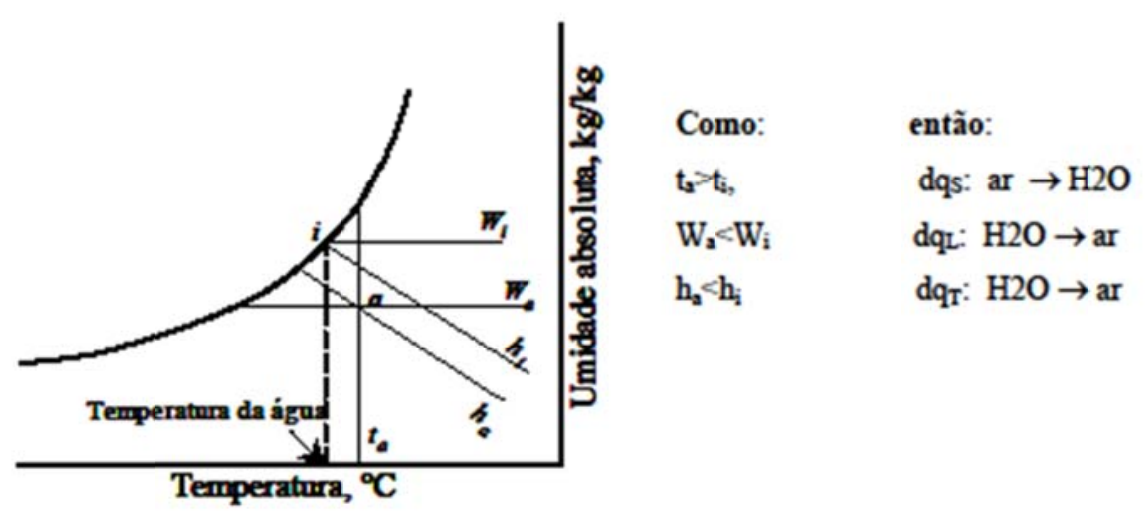

Figura 2.8 - Transferência de calor total da água para o ar Fonte: STOECKER e JONES, 1985 
A eficiência dos processos de resfriamento evaporativo, que podemos assumir como a relação entre a queda real da temperatura do bulbo seco produzida pelo sistema e a temperatura do bulbo seco que se poderia atingir se o sistema de resfriamento fosse $100 \%$ eficiente, sendo o ar de saída, saturado, ou seja, a eficiência do sistema de resfriamento evaporativo está em conseguir que a temperatura do bulbo seco do ar de saída seja igual temperatura do bulbo úmido do ar admitido (TRANE, 1978). Essa condição deixa claro que quanto maior a umidade relativa do ar de admissão tanto menor será a eficiência da queda de temperatura do processo evaporativo.

Nos sistemas passivos avaliados por GIVONI (1994), o valor da temperatura de bulbo seco atingida é superior a temperatura do bulbo úmido em cerca de 20 a $40 \%$, o que equivale a uma eficiência de saturação entre $60 \%$ e $80 \%$ respectivamente. De um modo geral, arbitrariamente, adota-se uma eficiência de saturação de 70\% para os sistemas mecânicos de resfriamento evaporativo (ASHRAE, 1995), incluindo-se os sistemas de spray (RORIZ, 2000; LOMAS et al., 2004). 


\section{CONFORTO TÉRMICO E ECONOMIA ENERGÉTICA}

Compreender o significado de conforto térmico é importante não só para se estabelecer as bases de projetos construtivos, mas também afeta a campo do design sustentável. Os modelos de conforto térmico recomendam uma estreita faixa de temperatura para ser aplicada igualmente em todos os tipos de construção, zonas climáticas, e populações. Este método destaca os ocupantes da edificação climatizada como receptores passivos de aplicações térmicas, levando a padrões de conforto térmico que exigem um intensivo controle das condições ambientais das estratégias de consumo de energia. Novas pesquisas estão inovando os projetos de sistemas de ventilação e ar condicionado (HVAC), pois estão desafiando as noções aceitas referentes aos parâmetros de conforto térmico universais uma vez que estes parâmetros subestimam as condições culturais e fatores contextuais de conforto.

As quedas na disponibilidade dos recursos energéticos junto com um despertar consciência ambiental criaram um interesse em sensação térmica aliado a consumo energético. Projetos mecânicos inovadores junto com estratégias que permitem um controle mais pessoal das condições de conforto térmico têm provocado um aumento do interesse em substituir o tradicional padrão conforto por padrões que permitem variar a temperatura interior e consequente redução do consumo energético. As normas estabelecidas para estes projetos permitem um emprego de uma escala mais ampla psicrométrica.

Este modelo revisto de conforto térmico nos coloca um passo à frente para o aumento eficiência energética na construção de projeto de climatização vinculados a temperaturas interiores que atendem conjuntamente tanto aos ocupantes como as atividades que desenvolvem no interior da área climatizada.

O valor da umidade relativa máxima a ser atingida pode ser definido pelo usuário, de tal forma que esta não interfira negativamente na sensação de conforto térmico. $O$ valor máximo possível de ser atingido define a máxima redução de temperatura do ar e consequentemente o máximo desempenho do sistema. Se por um lado o conforto é obtido pela limitação da umidade máxima, por outro lado estes limites definirão o potencial de resfriamento do sistema e seus limites operacionais. Os limites aceitáveis para a umidade relativa ainda são bastante discutidos, assim como a validade deste parâmetro e os efeitos da climatização. 
Um dos índices mais amplamente conhecidos para se definir o potencial de resfriamento do sistema é a temperatura efetiva $(T E)$, que em síntese traduz a sensação térmica. A temperatura efetiva é um índice subjetivo, elaborado em 1923 a pedido da atual ASHRAE, que considera conjuntamente a temperatura de bulbo seco, temperatura de bulbo úmido e velocidade do ar. Sabendo-se que nossa percepção de conforto ou desconforto não depende exclusivamente da temperatura do ar, mas da combinação das demais variáveis. Dois ambientes com a mesma $T E$ devem gerar a mesma sensação térmica, embora tenham diferentes temperaturas e umidades. A Temperatura Efetiva de conforto está na faixa de 22 a $27^{\circ} \mathrm{C}(\mathrm{ABNT}, 1978)$.

Segundo WATT E BROWN (1997), para atingir um nível satisfatório de conforto com resfriamento evaporativo direto, deve-se, em primeiro, absorver o calor do ambiente de origem interna e externa e carregá-lo para fora e, em segundo, induzir uma circulação de ar suficientemente rápida para estimular a transferência de calor na pele humana.

No Brasil, em virtude de haver predominância de climas quentes e úmidos, especial atenção deve ser dada à comprovada influência do desconforto térmico tanto na disposição para o trabalho como nas atividades desenvolvidas. Sob esse aspecto, convém ressaltar que as condições térmicas dos ambientes de trabalho não dependem só do clima, mas também do calor introduzido pelas atividades desenvolvidas e pelos equipamentos envolvidos nos processos produtivos e, também, pelas características construtivas do ambiente e a sua capacidade de manter condições internas adequadas no que se refere ao conforto térmico das pessoas.

\subsection{O Conforto Térmico Definido}

O conforto térmico num determinado ambiente pode ser definido como a sensação de bem-estar experimentada por uma pessoa, como resultado da combinação satisfatória, nesse ambiente, da temperatura radiante média $\left(T_{r m}\right)$, umidade relativa $(\varnothing)$, temperatura do ambiente $\left(T_{a}\right)$ e velocidade relativa do ar $\left(V_{r}\right)$, com a atividade desenvolvida e com a vestimenta usada pelas pessoas. Devido à sua subjetividade, conforto térmico é diferente para cada indivíduo. Ele é mantido quando o calor gerado pelo metabolismo humano é dissipado a uma velocidade que mantém o equilíbrio térmico no corpo. Qualquer ganho ou perda de calor para além desta condição gera desconforto substancial. Assim, entende-se como condições 
ambientais de conforto aquelas que propiciam bem-estar ao maior número possível de pessoas.

Tem sido desde há muito reconhecido que a sensação de calor ou frio é dependente de fatores que vão muito além da temperatura do ar. Na verdade, existem seis variáveis conforto térmico principais:

Variáveis ambientais:

- A temperatura ambiente (temperatura do ar) ou temperatura do bulbo seco;

- A temperatura radiante (a temperatura das superfícies em torno de nós);

- Umidade Relativa (medida de o vapor de água numa mistura de ar-água)

- Movimento do ar (a taxa na qual o ar se move ao redor ou se renova no ambiente).

Variáveis de natureza pessoal:

- Taxa metabólica (quantidade de energia gasta para suprir as atividades desempenhadas);

- Isolamento Vestuário (Roupas utilizados para reter ou remover calor do corpo).

Entender essas variáveis, é essencial para se estabelecer as condições operacionais de um sistema de climatização. No entanto, é igualmente importante compreender como a operação destes sistemas interferem nas características das atividades desenvolvidas e, também, como impactam a carga de energia consumida.

FIALA et al. (1999) avaliaram a sensação térmica produzida por sistemas de resfriamento evaporativo por corrente de ar descendente (passive downdraught evaporativa cooling $-P D E C)$, que consiste na produção de névoa por micro aspersão na parte superior de uma torre que conduz o ar resfriado para o ambiente através de aberturas na parte inferior. Frequentemente estes sistemas produzem ambientes com temperatura entre 24 e $28^{\circ} \mathrm{C}$ e umidade acima de $80 \%$, entretanto, não foi identificada a influência da umidade no estado térmico do corpo humano, na percepção de conforto e na aceitabilidade térmica, nesta faixa de temperatura e com velocidade do ar em $0,8 \mathrm{~m} / \mathrm{s}$.

ASHRAE (1995) apresenta estudos nos quais é possível verificar que a redução da temperatura do bulbo seco $\left(T_{a}\right)$ devido à evaporação da água sempre resulta em uma redução da Temperatura Efetiva (TE), independente da umidade relativa. Tomando, como exemplo, condições externas de $35^{\circ} \mathrm{C}$ para $T_{a}$ e de $24^{\circ} \mathrm{C}$ para temperatura do bulbo úmido $\left(T_{m}\right)$, pôde- 
se verificar que a redução de $T_{m}$ em $8 \mathrm{~K}$ promoveu uma redução de $T E$ de $3 \mathrm{~K}$, para ar com velocidade de $0,1 \mathrm{~m} / \mathrm{s}$, e de $5 \mathrm{~K}$, para ar com $3,5 \mathrm{~m} / \mathrm{s}$. A Figura 3.1, a seguir, demonstra o comportamento da $T E$ diante da utilização de um resfriador evaporativo de $80 \%$ de eficiência de saturação.

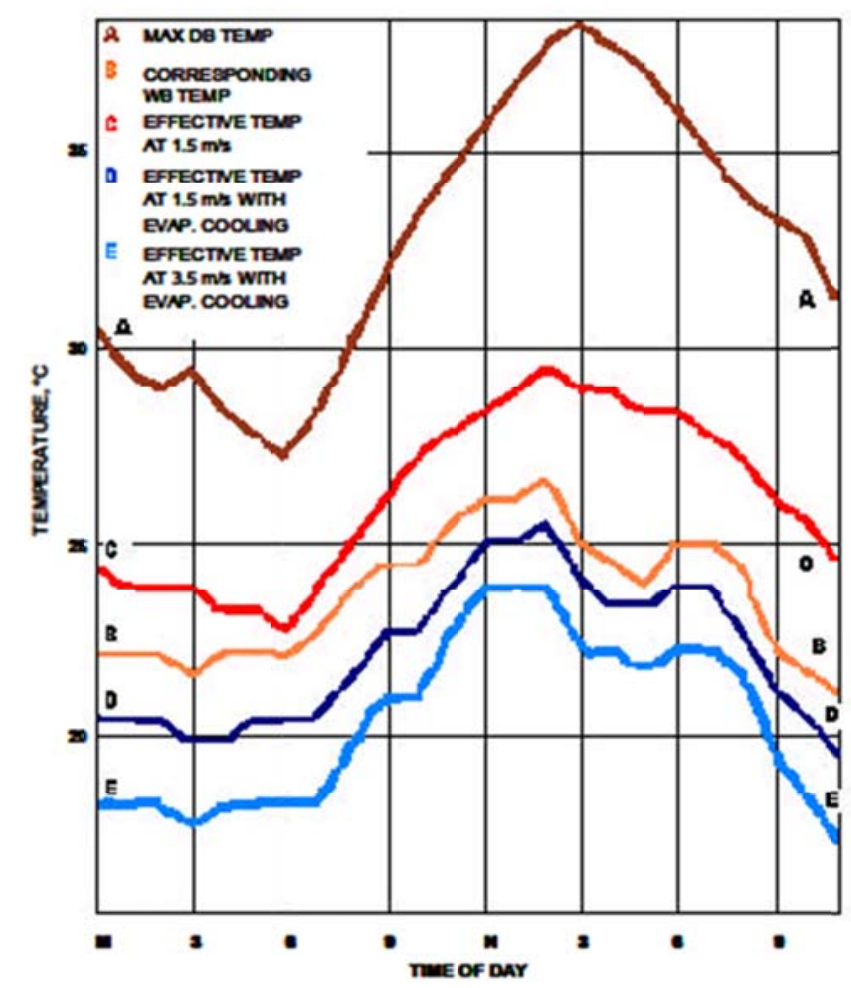

Figura 3.1 - Temperatura Efetiva para um dia de verão em Kansas City, Missouri Fonte: ASHRAE (1995)

Segundo GIVONI (1991), em sistemas de resfriamento evaporativo direto a temperatura do ar é reduzida em cerca de $70-80 \%$ da diferença entre $T_{m}$ e $T_{a}$ e o parâmetro climático de sua aplicabilidade é o máximo $T_{m}$. A utilização deste sistema tem por característica o aumento da umidade relativa do ar e necessita de taxas elevadas de fluxo de ar justamente por essa alta umidade que o ar resfriado contem e que estabelece a temperatura interior. Em edifícios bem isolados, essa temperatura é cerca de 1 a $2^{\circ} \mathrm{C}$ acima da temperatura do ar que sai do resfriador evaporativo.

Considerando os efeitos da alta umidade e uma velocidade do ar de cerca de $2 \mathrm{~m} / \mathrm{s}$, GIVONI (1992) sugere que o resfriamento evaporativo direto seja usado, somente onde e quando a $T_{m}$ máxima for próximo a $22^{\circ} \mathrm{C}$ e $T_{a}$ máxima for próxima a $42^{\circ} \mathrm{C}$, em países desenvolvidos. Em países de clima quente em desenvolvimento, considerando a climatização, 
os limites sugeridos pelo autor são de $24^{\circ} \mathrm{C}$ para $T_{m}$ e $44^{\circ} \mathrm{C}$ para $T_{a}$. A figura 3.2 mostra as regiões em carta psicrométrica, e suas correspondências:

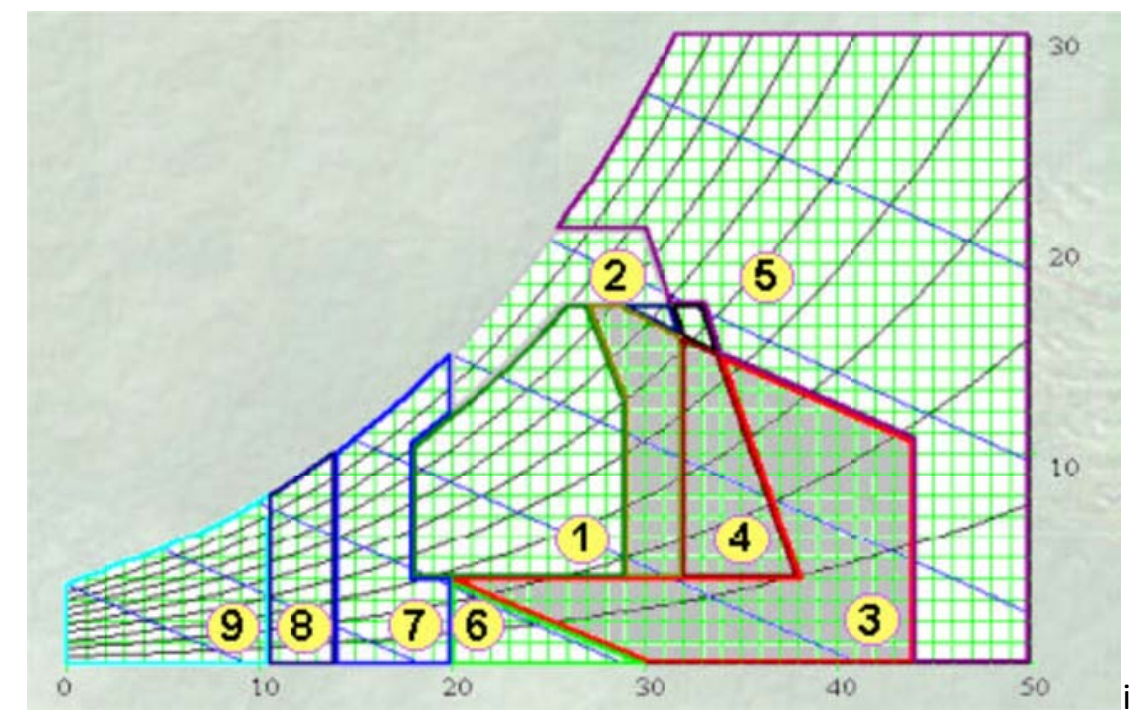

Figura 3.2 - Carta psicrométrica para aplicação do resfriamento evaporativo Fonte: LAMBERTS et al. (1997)

onde: 1- Zona de Conforto; 2- Zona de Ventilação; 3- Zona de Resfriamento Evaporativo; 4Zona de Massa Térmica para Resfriamento; 5- Zona de Ar Condicionado; 6- Zona de Umidificação; 7- Zona de Massa Térmica e Aquecimento Solar Passivo; 8- Zona de Aquecimento Solar Passivo; 9- Zona de Aquecimento Artificial.

GIVONI (1991), afirma que a temperatura interna em edifícios residenciais condicionados por resfriamento evaporativo depende do fluxo de ar resfriado, das características do isolamento do edifício e de sua carga térmica. Assim, estes limites de aplicabilidade referem-se ao uso residencial de técnicas passivas de resfriamento, frente a algumas condições características do uso como a carga térmica e eficiência do processo evaporativo.

Adotando arbitrariamente uma eficiência de saturação de $70 \%$, sem que isso faça referência a algum tipo específico de sistema de resfriamento evaporativo, RORIZ (2000) elaborou um zoneamento de potencial de resfriamento evaporativo para o estado de São Paulo. Como resultado, $52 \%$ do território do estado ofereceu um potencial diário de mais de 20 pontos de redução no desconforto provocado pelo calor para um dia médio de fevereiro. No zoneamento bioclimático do CE-02 (1998) mais de 50\% do território de São Paulo está classificado em zonas bioclimáticas (zona 3 e 5) que classificam o resfriamento evaporativo como de "uso proibido". A cidade de Pindamonhangaba, cuja Figura 3.3 apresenta o 
desempenho de uma instalação de um sistema de resfriamento evaporativo, teria "uso proibido" se baseado nesta estratégia bioclimática.
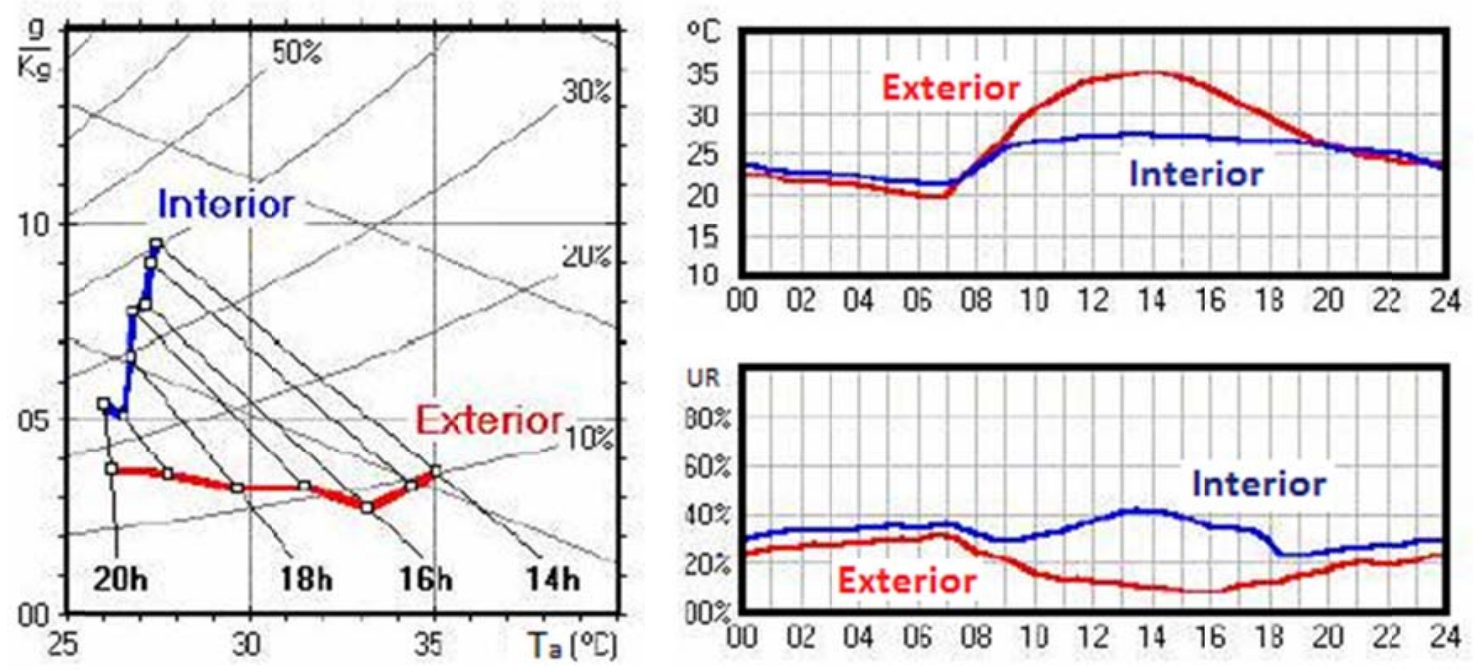

Figura 3.3 - Temperatura e umidade medidas no pavilhão industrial com sistema de micro aspersão em Pindamonhangaba - SP.

Fonte: RORIZ (2000).

Fica evidente que o desempenho dos sistemas de resfriamento evaporativo é função não só das condições exteriores, mas também da eficiência do equipamento, das cargas térmicas envolvidas, das características da edificação e, podemos incluir, as atividades desenvolvidas.

Consequentemente, algumas cartas bioclimáticas que estabelecem o potencial de alcance de resultados em uma eventual aplicação do processo de resfriamento evaporativo, como forma de se obter conforto térmico, são válidas apenas para os sistemas experimentados e a utilização destas para avaliar a possibilidade de aplicação de sistemas resfriamento evaporativo mecânico, sem dúvida alguma, constitui um erro.

A importância da aplicabilidade dos sistemas de resfriamento evaporativo está na correta avaliação das variáveis que interferem no processo do resfriamento por micro aspersão. Existem limites de aplicabilidade em todas as condições analisadas pelos autores estudados, ponto este, que indica a busca por um projeto de instalação que nos permita um maior controle destas variáveis com maior ênfase. 


\subsection{Condições de Conforto Térmico e Consumo de Energia}

Os dados apontam que de toda energia consumida na nossa estrutura funcional, $44 \%$ é utilizada no resfriamento para conforto térmico, figura 3.4, ou seja, quase metade da energia utilizada na nossa sociedade é consumida para produzir ambientes mais adequados as pessoas e atividades desenvolvidas. Os estudos dos padrões de consumo têm mostrado desperdícios. Criar projetos que podem ajudar a reduzir os padrões de consumo é assunto de extensa pesquisa.
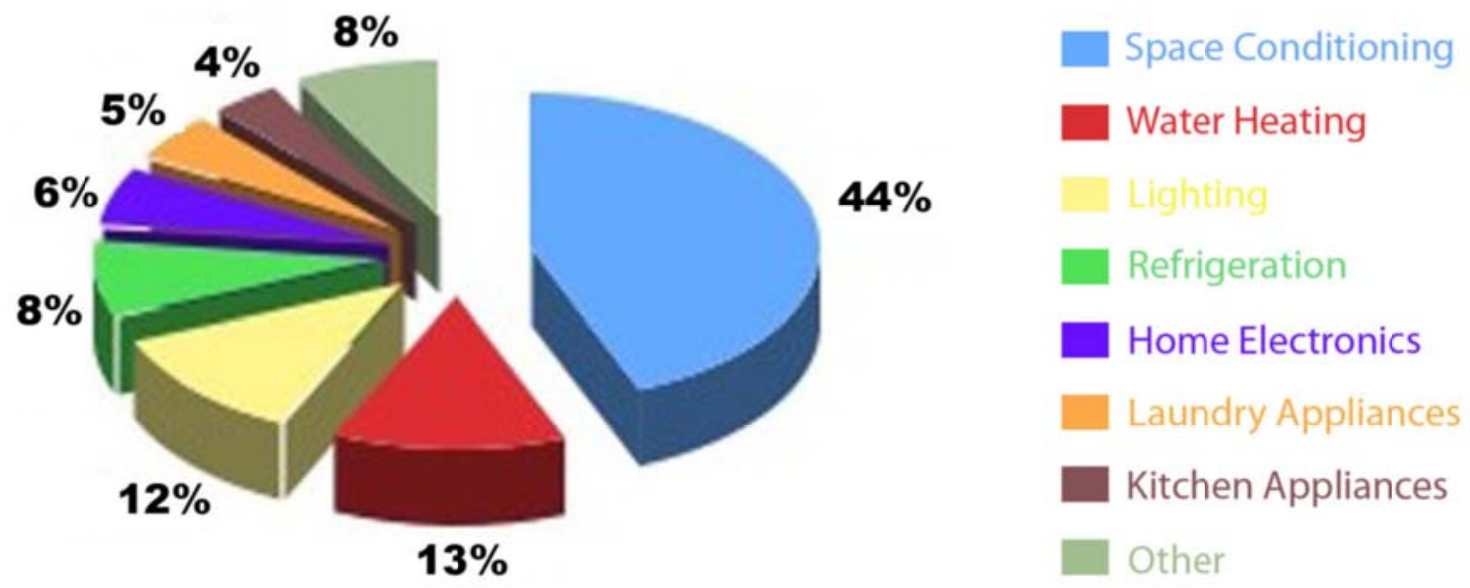

Figura 3.4 - Consumo de energia na nossa estrutura funcional. Fonte: NICOL (1995).

A utilização mais eficiente da energia é de grande interesse das empresas devido à necessidade crescente de se criar formas de utilização mais consciente dos recursos disponíveis e, claro, ao ganho financeiro proporcionado. Nessa linha, a utilização de sistemas de resfriamento evaporativo tem sido crescente, onde a economia energética está diretamente ligada a eficiência do processo ou de funcionamento de seus componentes.

AHSRAE (1995) especifica que uma combinação de dois fatores deve ser considerada no dimensionamento de sistemas de climatização. O primeiro refere-se aqueles que interferem nas condições ambientais internas e o segundo são aqueles que determinam as condições de conforto térmico sensível a maioria das pessoas que ocupam o local. Existem duas formas que ajudam a decidir qual combinação de fatores deve ser aplicada no dimensionamento. São elas:

- Analítica: As pessoas são colocadas em um ambiente com temperatura controlada e suas respostas são monitorados. Este método favorece ambientes altamente 
controlados e os resultados são usados para desenvolver um modelo que pode ser utilizado para prever o máximo de conforto.

- Comportamental: As pessoas são monitoradas em seus ambientes normais e as suas respostas estão relacionadas com as condições que eles experimentam. Os resultados são analisados estatisticamente para desenvolver uma compreensão da interação entre as pessoas e edifícios.

Estas duas abordagens geram resultados diferentes, especialmente em condições ambientais variáveis. A abordagem analítica usa softwares específicos que controlam as condições de conforto térmico. $\mathrm{Na}$ abordagem comportamental, apenas um gráfico psicrométrico é aplicado.

Para uma análise mais aprofundada desta última aplicação, é importante considerar os sistemas de refrigeração ao longo de sua evolução histórica e o que se pode aprender esse passado.

Anterior ao desenvolvimento de sistemas de ar condicionado mecânicos, sociedades usavam métodos naturais para resfriamento ambiental, como sombreamento e ventilação natural, com a finalidade de alcançar o conforto térmico. Tais métodos têm sido utilizados por milhares de anos.

A Sociedade afastou estes métodos quando o resfriamento mecânico se tornou disponível no início de 1900. Em 1902, o primeiro sistema de refrigeração mecânica foi construído e quatro anos mais tarde, o primeiro edifício de escritórios foi projetado utilizando um sistema de condicionamento ar. Em 1929, o primeiro refrigerador de quarto entrou no mercado, em 1931 marcou a primeira vez que sistemas de ar condicionado central se tornou disponível para utilização e, em 1947, a unidade de ar condicionado de janela estava sendo produzido em massa. Devido a estas realizações ao longo do século, a indústria de ar condicionado mecânico lidera os índices em crescimento no consumo de energia.

Se por um lado o advento do ar condicionado possibilitou um ambiente interior mais confortável, por outro lado ele ignorou completamente as condições climáticas regionais. Por exemplo, tomando por base as características climáticas no Brasil, onde o clima na região sul tende a ser mais frio e seco, na região norte quente e úmido e na região nordeste, quente e 
seco, a base para o dimensionamento de instalação de equipamentos de ar condicionado é a mesma. Essa condição faz com que equipamentos que haviam funcionado de forma eficiente em determinada região passa a consumir quantidades excessivas de energia em outra. Além disso, nosso padrão construtivo, até então, não priorizava em projeto estudos ambientais, fazendo de nossas edificações pouco eficientes em relação ao consumo de energia referente à manutenção de ambientes confortáveis.

Antes da crise energética de 1970, a variação na umidade relativa raramente era considerada na escolha de materiais usados na construção do edifício. Essa não observação tem um enorme impacto sobre a qualidade do ar interior. Durante este tempo, os edifícios foram construídos livremente, com isolamento deficiente e, essa característica construtiva, resultou em uma carga sensível adicional, fazendo com que as unidades de ar condicionado tivessem uma maior frequência de funcionamento.

Após a crise energética de 1970, normas de construção rigorosos começaram a surgir para melhorar a eficiência energética do edifício. Essas normas mais rigorosas, por outro lado, também fizeram com que o equipamento de condicionamento se tornasse mais eficiente. Até hoje, as características operacionais do equipamento continuam a ser otimizadas para a carga de calor sensível, mas ainda ignorando a carga de umidade.

Os seguintes fatores surgiram destes padrões desenvolvidos e das mudanças feitas na maneira que nós projetamos e construímos nossos edifícios:

- A carga sensível no edifício foi reduzida, no entanto, o nível de umidade permaneceu o mesmo. Embora as mudanças nos padrões de construção de nossos edifícios, efetuadas após a crise energética de 1970, e o desenvolvimento de equipamentos mais eficientes, não evitaram os problemas relacionados a umidade relativa. $\mathrm{O}$ foco nas cargas sensíveis (temperatura) caracteriza que a umidade foi ignorada no projeto do sistema.

- Com o aumento das exigências de ventilação mais umidade foi adicionado ao ambiente com ar ventilado. 
- A conscientização formada na melhoria da qualidade do ar interior se traduzia em aumento da capacidade de resfriamento e, com isso, condições internas de baixa umidade eram esperadas.

Apesar da crise ter resultado em edifícios energeticamente mais eficientes, a qualidade do ar interior diminuiu, como resultado de cargas umidade não abordadas.

A lição importante trazida pelas características históricas dos processos de climatização é que:

- Os projetos devem controlar a umidade e não apenas a temperatura.

- Os sistemas de ar condicionado se padronizaram ao longo do tempo, trazendo de volta a necessidade utilizarmos sistemas passivos para o controle da umidade, muitas vezes em conjunto com os sistemas mecânicos especificamente projetados.

- Projetos de climatização que envolvem sistemas mais eficientes em termos energéticos, por considerar não só os ocupantes naquele espaço, como também as atividades ali desenvolvidas, têm sido mais frequentes que projetos de construção e ar condicionado que não consideram quem está usando o espaço (ou como ele é usado).

À nível de eficiência energética, os sistemas de climatização devem ser adaptados para o contexto climático local da edificação, sendo responsável por ambas a temperatura e a umidade. Nos extremos, a consideração não só no pico de temperatura, mas as condições de umidade referentes a esse pico de temperatura, também, ou seja, projetar corretamente um sistema de climatização é aplicar o conceito de psicrometria à concepção do sistema, uma vez que psicrometria considera os fatores de clima local, ocupação humana e conforto, e vários controles de temperatura e umidade.

WATT E BROWN (1997) salientam que a comparação da taxa de resfriamento entre sistemas de resfriamento evaporativo direto e sistemas de condicionamento de ar deve ser feita através da conversão de calor sensível, pois o primeiro não retira calor do ar resfriado, mas o converte em calor latente. 
Um meio de comparação utilizado é a Razão de Eficiência Energética (Energy Efficiency Ratio - EER), desenvolvida para comparar o desempenho de condicionadores de ar, não de resfriadores evaporativos. EER representa a relação da taxa de remoção de calor no resfriamento do ar por potência elétrica consumida (ASHRAE, 1995). Estes estudos se estenderam a um resfriador evaporativo indireto e indicaram que a $E E R$ desse resfriador pode ser $70 \%$ maior que a de um condicionador de ar convencional.

A Tabela 3.1 a seguir, demonstra a economia de energia alcançada em algumas cidades norte-americanas com a utilização de resfriamento evaporativo em substituição a sistemas tradicionais de condicionadores de ar.

Tabela 3.1 - Economia anual de energia com resfriamento evaporativo em cidades dos Estados Unidos.

\begin{tabular}{lcc|cc|ccc|cc}
\hline & \multicolumn{2}{c}{$\begin{array}{c}\text { Evaporative } \\
\text { Cooler }\end{array}$} & $\begin{array}{c}\text { High Eff. } \\
\text { Refrig'n }\end{array}$ & $\begin{array}{c}\text { Saved } \\
\text { by E.C. }\end{array}$ & $\begin{array}{c}\text { Standard } \\
\text { Refrig'n }\end{array}$ & $\begin{array}{c}\text { Saved } \\
\text { by E.C. }\end{array}$ & $\begin{array}{c}\text { Heat } \\
\text { Pump }\end{array}$ & $\begin{array}{c}\text { Saved } \\
\text { by E.C. }\end{array}$ \\
\cline { 2 - 10 } & $\begin{array}{c}\text { Power } \\
\text { kwh }\end{array}$ & $\begin{array}{c}\text { Water } \\
\text { gal. }\end{array}$ & kwh & kwh & kwh & kwh & kwh & kwh \\
\hline Burbank & 1305 & 5.086 & 4175 & $69 \%$ & 4995 & $74 \%$ & 4287 & $70 \%$ \\
Phoenix & 2500 & 21.639 & 9681 & $74 \%$ & 10.255 & $76 \%$ & 8818 & $72 \%$ \\
El Paso & 1872 & 11.636 & 5868 & $68 \%$ & 6998 & $73 \%$ & 5957 & $69 \%$ \\
Denver & 627 & 3.480 & 1994 & $69 \%$ & 2245 & $72 \%$ & 2063 & $70 \%$ \\
Spokane & 415 & 2.168 & 1380 & $70 \%$ & 1554 & $73 \%$ & 1430 & $71 \%$ \\
\hline TOTALS & 6.719 & 44.009 & 23.098 & $70.9 \%$ & 26.047 & $74.2 \%$ & 22.555 & $70.2 \%$ \\
\hline
\end{tabular}

Fonte: WATT e BROWN (1997)

GIVONI (1994) cita um estudo comparativo do consumo de energia (kWh) em função de "graus dia de resfriamento" (Cooling Degree Days - CDD) de um sistema de resfriamento evaporativo direto, indireto (duplo estágio) e um compressor de condicionador de ar (bomba de calor). O sistema direto utilizou $1 / 4$ e o indireto $1 / 3$ da energia consumida pelo condicionador de ar, como observado na figura 3.5, a seguir: 


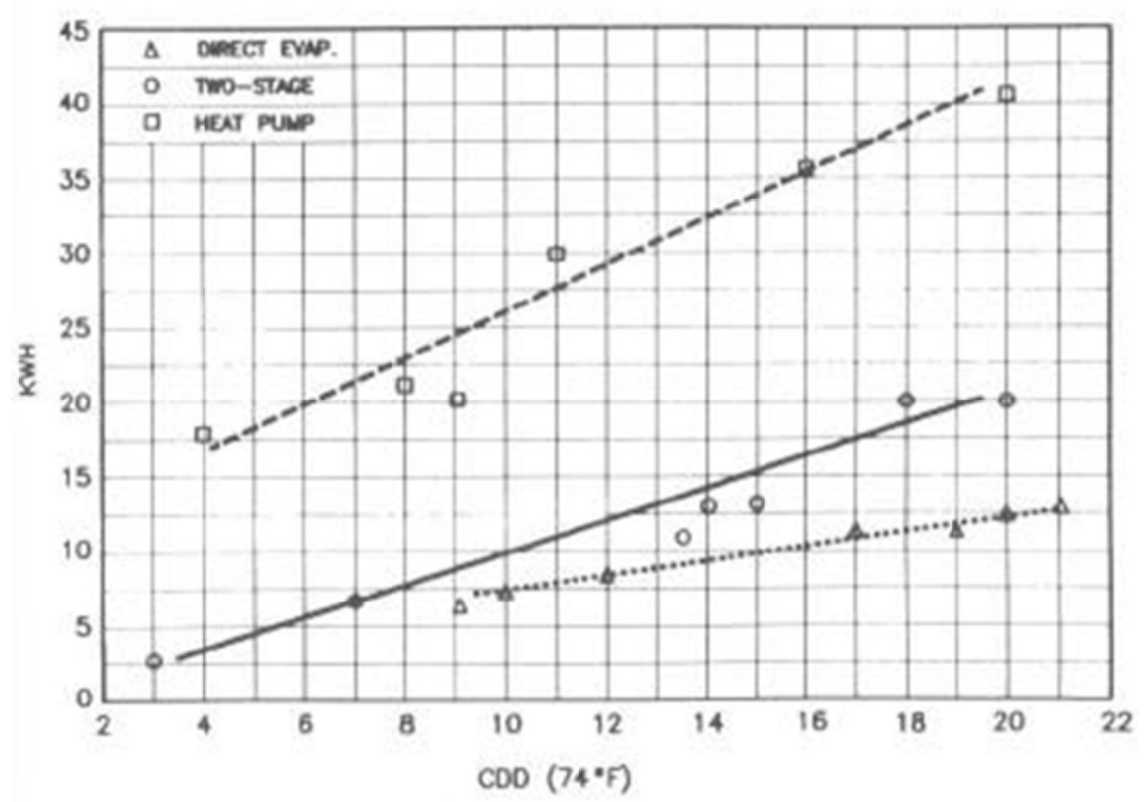

Figura 3.5 - Comparação do consumo de energia kWh/CDD Fonte: GIVONI (1994)

Apesar de haver determinadas regiões onde substituir o sistema de condicionamento de ar por sistemas de resfriamento evaporativo poderia ser feito sem que isso alterasse significativamente as condições de conforto térmico, essa substituição não é muito comum. A aplicação mais comum é utilizar o resfriamento evaporativo como pré-resfriador do ar de captação e, com isso, reduzir a carga térmica anual dos equipamentos de ar condicionado.

Os compressores têm sua eficiência inversamente proporcional à temperatura do ar que entra no condensador. Resfriando o ar exterior que entra no condensador, diminui sua pressão interna e, como consequência, o trabalho do compressor e do motor. As economias são significativas, primeiro porque a capacidade de refrigeração também aumenta, segundo compressores menores podem lidar com maiores picos de carga de resfriamento, reduzindo capital investido e espaço ocupado. Finalmente os compressores necessitarão de menos manutenção e manutenções mais espaçadas (WATT $e$ BROWN, 1997).

O efeito do pré-resfriamento na pressão, consumo de energia e capacidade de refrigeração de um condicionador de ar está demonstrado na figura 3.6 abaixo. A linha cheia representa o desempenho com o pré-resfriamento e a linha pontilhada representa o desempenho do equipamento sem essa aplicação: 

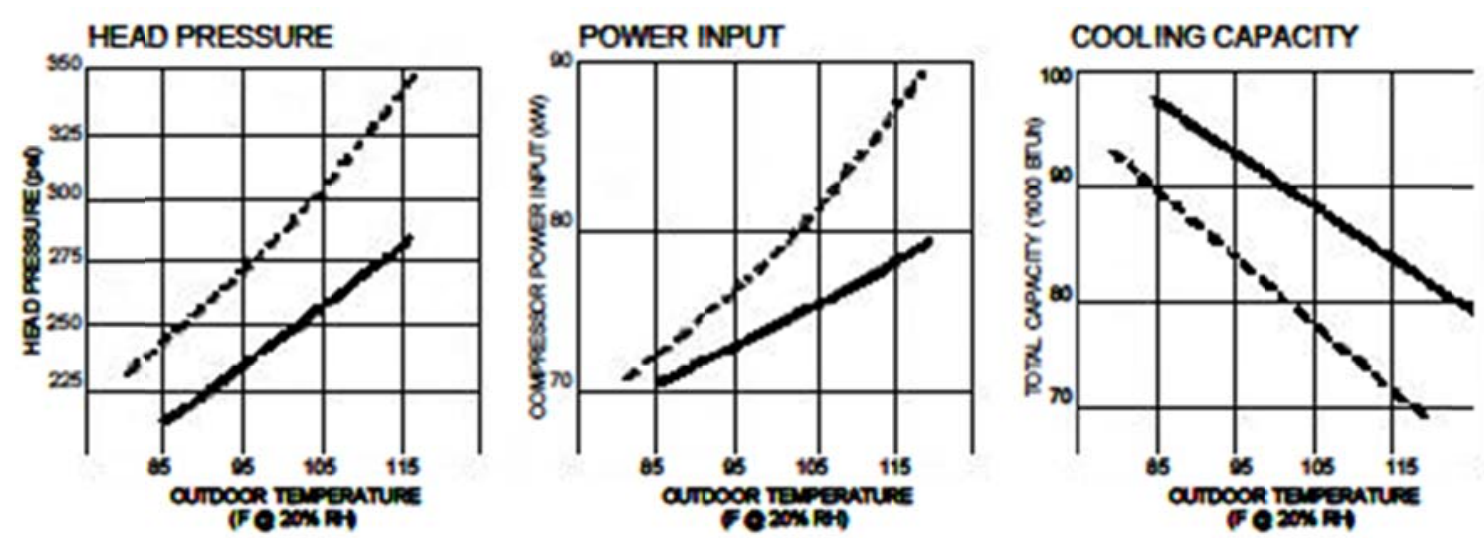

Figura 3.6 - Economia verificada com a utilização de pré-resfriamento evaporativo Fonte: WATT e BROWN (1997)

Em casos de temperaturas elevadas, os equipamentos convencionais de condicionamento de ar têm seu funcionamento prejudicado devido à alta temperatura na serpentina do condensador. A solução utilizada é o pré-resfriamento do ar admitido pelo condensador. Testes mostraram que, com este procedimento, o EER (energy efficiency ratio) das unidades pode ser melhorado em até $55 \%$ e a demanda (em quilowatt) reduzida em até 33\%, dependendo das circunstâncias climáticas. A figura 3.7 mostra uma instalação de um sistema de condicionamento de ar com pré-resfriamento.

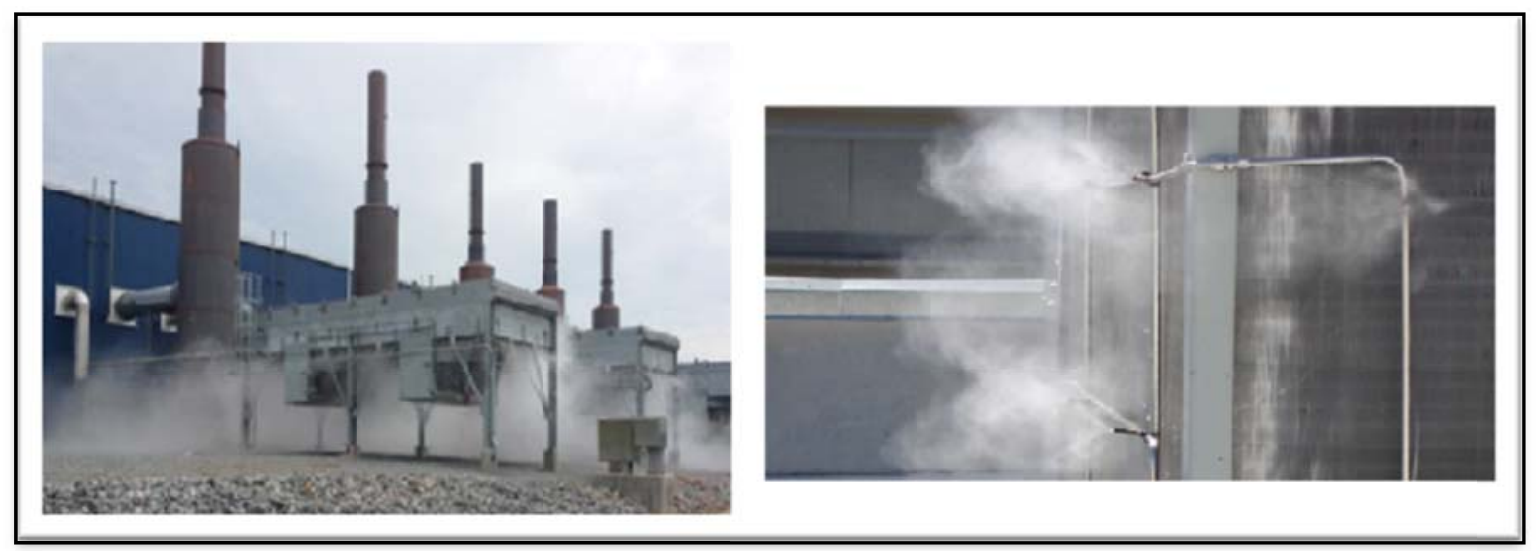

Figura 3.7 - Pré-resfriamento de condensador aplicado em condicionador de ar Fonte: Instalação executada pelo autor em 2014 - Meridiano - SP

A lição que fica:

- Sob o conceito de conforto térmico aliado a uma maior eficiência energética, os projetos de climatização devem estar vinculados a condições de clima interior que atendam tanto os ocupantes quanto as atividades que são desenvolvidas no interior 
da área climatizada. Devemos, então, não só considerar a temperatura como também a umidade relativa e, sob essa ótica, buscar atingir um máximo de umidade possível sem que a sensação de conforto térmico seja comprometida.

- Ao se atingir a máxima umidade possível, estamos estabelecendo a o máximo grau de resfriamento que podemos dispor ao sistema e, consequentemente, seus limites operacionais. A busca pela temperatura efetiva $(T E)$ ganha força nos projetos por envolver o conceito de sensação térmica, conceito esse, que alia a temperatura, umidade e velocidade do ar. O máximo valor da umidade significa que calor foi absorvido e a velocidade do ar que vai configurar a sensação de conforto térmico.

- A eficiência energética está diretamente ligada ao desempenho dos sistemas de resfriamento evaporativo, ou seja, ao processo de resfriamento que, no nosso caso é a eficiência do equipamento aliada as cargas térmicas envolvidas advindas tanto das condições externas quanto das atividades ali desenvolvidas. Eficiência energética é igual a eficiência do processo.

A aplicabilidade dos sistemas de resfriamento evaporativo está na correta avaliação das variáveis que interferem no processo, uma vez que as características do espaço a ser climatizado são únicas. Existem limites de aplicabilidade em todas as condições analisadas pelos autores estudados, ponto este, que nos remete a busca por um projeto de instalação que, de alguma forma, permita estabelecer um controle destas variáveis com maior ênfase. 
O processo de atomização ocorre quando um jato ou lâmina de líquido se desintegra devido à energia cinética do próprio líquido, ou por exposição a uma alta velocidade do ar, ou como resultado de uma energia mecânica aplicada externamente através de dispositivos rotacionais ou vibracionais. Devido à natureza randômica do processo de atomização, o spray resultante é usualmente caracterizado por um amplo espectro de tamanhos de gota (LEFEBVRE, 1989).

Os sprays são os componentes principais do sistema de resfriamento evaporativo por micro aspersão. Estes sistemas, também denominados sistemas de atomização descreve o sistema de resfriamento, citado por WATT E BROWN (1997) como alternativa de resfriamento de áreas externas, porém, não constando entre as técnicas de resfriamento evaporativo de ambientes internos.

Os sistemas de micro aspersão caracterizam-se pela aspersão de gotículas de água tão minúsculas (entre 10 e $20 \mu \mathrm{m}$ ) que estas evaporam completamente e rapidamente quando em contato com o ar, retirando calor e baixando sua temperatura, sem molhar nem projetar água líquida sobre as pessoas próximas, embora a névoa seja visível (GIVONI, 1994).

Como toda água atomizada evapora na área a ser resfriada a redução da temperatura é bastante rápida. A atomização da água é feita através de bomba de pistão que, em alta pressão, força a saída da água por bicos aspersores com orifícios de pequeno diâmetro $(0,2$ a 0,5 mm), distribuídos homogeneamente pelo ambiente conforme a necessidade e a geração de calor interno, sendo possível, climatizar por igual o espaço considerado. A figura 4.1 mostra a névoa produzida pelo spray e a bomba de pistão responsável pela atomização. 

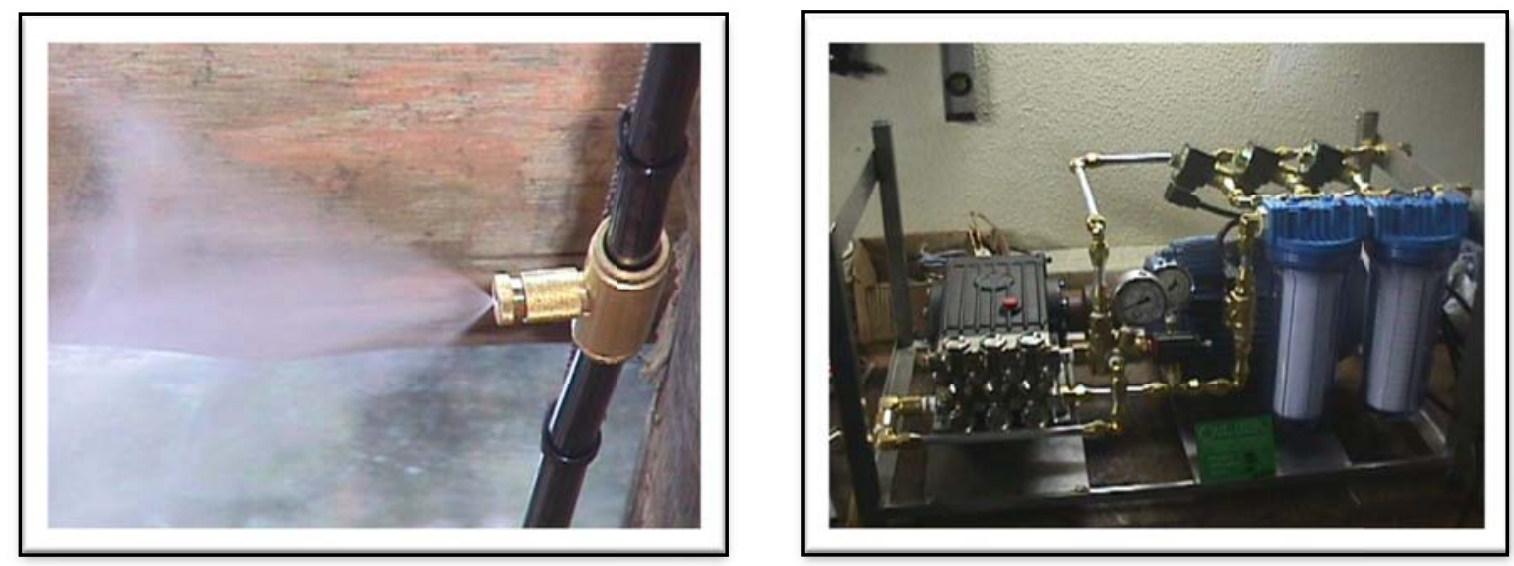

Figura 4.1 - O micro aspersor em operação e o sistema de pressurização Fonte: Instalação executada pelo autor em 2003 - Cianorte - PR

O módulo de pressão, responsável pela atomização da água, são dimensionados especificamente para as necessidades de cada aplicação, respeitando sempre o padrão para geração de pressão positiva dentro da necessidade de cada área climatizada. Para se obter um tamanho de gota da ordem de 10 a $20 \mu \mathrm{m}$, com a pressão equalizada em toda extensão da rede de climatização, a montagem deve ser em conformidade com um projeto de forma a minimizar ao máximo as perdas de carga do sistema.

O módulo de pressão é constituído por motor elétrico e, bomba de pistão (pistões em cerâmica), afim de resistir a trabalhos em alta pressão, vazão suficiente para suprir os aspersores previstos para o local a uma pressão de 800 PSI (libras) ou 55 bar. Possui filtros com elementos filtrantes de 5 e 10 polegadas de tamanho, conforme a vazão necessária, com cartuchos 1 e 5 micra de polipropileno e carvão ativado, que eliminam todo excesso de sólidos da água evitando que seja prejudicada a performance dos bicos aspersores.

Este módulo de pressão comporta, ainda, um sistema de drenagem responsável pelo alivio da pressão da rede. Dentro de operações na condição automática, o que significa interrupções cíclicas precisas durante a aspersão, um sistema constituído por válvulas ON/OFF, acionada por solenoide que, instalada no módulo de pressãio, alivia a pressão da tubulação e drena parte da água. Esta pressão que fica retida nas linhas de aspersão, quando da interrupção cíclica, provoca um gotejamento pelos micros aspersores, caso não seja aliviada. 


\subsection{Atomizadores de Pressão (Bicos de Nebulização)}

A névoa produzida é a responsável direta do resultado da climatização. A uma determinada pressão, o micro aspersor, também chamado de aspersores (nozzles), produz uma névoa com um determinado tamanho de gota a uma determinada vazão, ou seja, qualquer variação da vazão altera a pressão do sistema e, consequentemente, altera o tamanho da gota produzida mudando completamente o padrão da evaporação. O mesmo ocorre para quaisquer alterações de pressão. A tabela 4.1 mostra as vazões dos aspersores em relação a a pressão de trabalho aplicada.

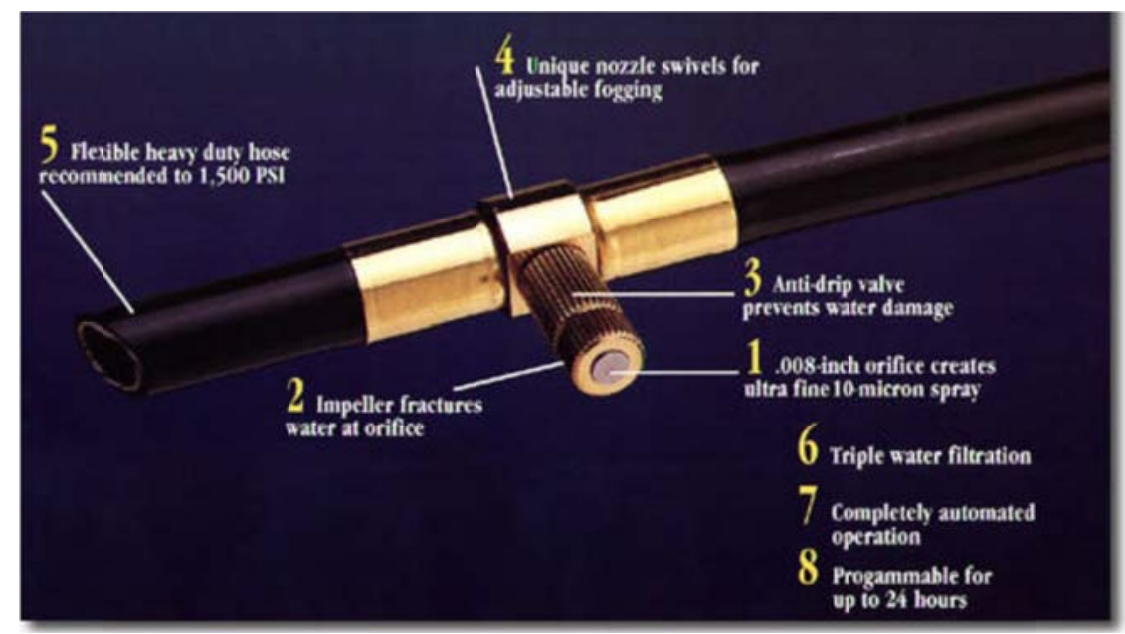

Figura 4.2 - Detalhe do micro aspersor apresentado pelo fabricante

Fonte: www.microcool.com

Esses bicos de nebulização, patenteados, são projetados para atingir uma velocidade extremamente alta com uma baixa taxa de fluxo. A água é atomizada em partículas de que evaporam instantaneamente em contato com o ar de ambiente, criando uma névoa fina. A atomização da água ocorre mesmo em climas com elevada umidade relativa.

A geração de névoa pelos bicos é rotativa, com o pino no interior do corpo do bico. Eles produzem uma névoa muito fina, com uma elevada percentagem de gotas de menos de 50 mícron de tamanho. Basicamente, o pino (impulsor) e o corpo do bocal são concebidos de tal maneira que o fluido é forçado através do orifício, produzindo um nevoeiro em forma de cone. É garantia do fabricante que os bicos de nebulização de alta pressão mantêm consistente as especificações de projeto, tolerâncias, e alta qualidade. 
Tabela 4.1 - Vazão dos bicos de atomização em função da pressão

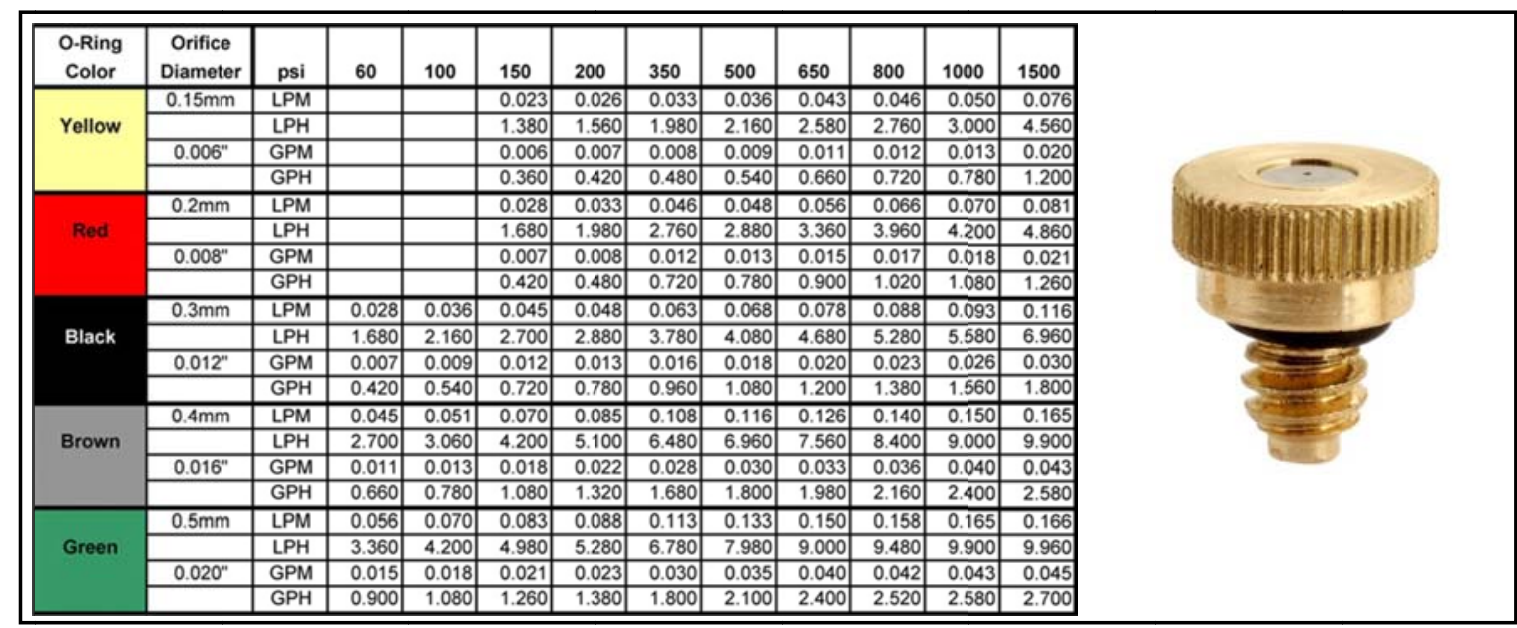

Fonte: www.amfog.com

A tabela acima indica as pressões e suas vazões correspondentes. Entretanto, o melhor resultado de névoa é obtido em determinadas faixas de pressão. As especificações seguem as seguintes descrições:

- 15 milímetros / 0,006" orifício (O-ring amarelo) - pressão mínima de 250 PSI e uma pressão máxima de 1500 PSI. O pulverizador é em forma de cone, com um ângulo de aproximadamente 55 a 70 graus. Esse bico com este tamanho de orifício produz o menor tamanho de gota. Isto pode ser ideal numa situação onde é desejado de umidade e fluxo limitados;

- 0,2 milímetros / 0,008" orifício (O-ring vermelho) - pressão mínima de 250 PSI e uma pressão máxima de 1500 PSI. O pulverizador é em forma de cone, com um ângulo de aproximadamente 55 a 70 graus;

- 0,3 milímetros / 0,012" orifício (O-ring preto) - pressão mínima de 45 PSI e uma pressão máxima de 1500 PSI. O pulverizador é em forma de cone, com um ângulo de aproximadamente 65 a 75 graus;

- 0,4 milímetros / 0,016" orifício (O-ring marrom) - pressão mínima de 45 PSI e uma pressão máxima de 1500 PSI. O pulverizador é em forma de cone, com um ângulo de aproximadamente 80 graus; 
- 0,5 milímetros / 0,020" orifício (O-ring verde) - pressão mínima de 45 PSI e uma pressão máxima de 1500 PSI. O spray é em forma de cone, com um ângulo de aproximadamente 80 graus.

Segundo LEFEBVRE (1989), durante a década passada houve uma grande expansão do interesse na tecnologia da atomização. Este crescimento do interesse tem sido acompanhado a largos passos pelas áreas de diagnóstico a laser para análise do spray e numa proliferação de modelos matemáticos para processos de combustão de sprays. Este avanço tecnológico é muito importante para que seja possível entender o processo da atomização, a capacidade e os limites dos dispositivos de atomização, de modo a melhor projetar e prever o desempenho de equipamentos e processos que dependem da atomização.

As características de densidade, velocidade das gotas e distribuição do tamanho das gotas como função do tempo e do espaço, são amplamente afetadas pela geometria interna do atomizador, pelas propriedades físicas do líquido e do meio gasoso no qual o líquido é aspergido, no nosso caso, no ar. O desenvolvimento do jato de líquido e o crescimento de pequenos distúrbios, que eventualmente conduzem à desintegração em ligamentos e gotas, são de importância primária em determinar a forma e tamanho do spray resultante.

Independentemente do tipo de atomizador, o principal objetivo dos sprays é incrementar a área superficial do líquido aspergido, assim, favorecer as taxas de troca de calor e massa deste com o ambiente. O foco está em calcular estas trocas de calor e massa, a fim de que seja possível avaliar o desempenho deste processo de resfriamento evaporativo.

Os atomizadores apresentados acima, são os atomizadores de pressão do tipo orifício plano (plan orifice) que são mais amplamente utilizados em umidificação e resfriamento. As diversas aplicações, no entanto, conduzem a diferentes pressões de trabalho. Os de baixa pressão produzem gotas maiores e são comumente utilizados com fins agrícolas. Já os de alta pressão, produzem gotas menores e são utilizados em atividades onde são necessárias elevadas taxas de troca de calor e massa, dentre as quais o resfriamento evaporativo de ambientes. 


\subsection{O Processo da Atomização}

Essencialmente, o processo de atomização necessita de uma alta velocidade relativa entre o líquido a ser atomizado e o ar ambiente. A atomização decorrente do choque entre o líquido e o ar ambiente resulta na ruptura da lâmina de líquido e posterior ruptura das gotas maiores em gotas menores. Vários estudos têm se dedicado a determinar experimentalmente a relação entre velocidade e comprimento de ruptura (breakup length), que é definido como o comprimento de jato contínuo, medido a partir do aspersor até o ponto de ruptura, onde ocorre a formação das gotas (LEFEBVRE, 1989).

Teoricamente o processo de atomização é composto de dois estágios:

- Primeiro estágio: O jato líquido emerge do aspersor em forma cilíndrica e contínua que, no choque com o ar gera forças coesivas e destrutivas que perturbam e provocam oscilações crescentes. A medida em que as oscilações vão aumentando provocam a ruptura do jato em gotas.

- Segundo estágio: Caracterizado quando da formação das gotas até as ocorrências após formadas, quando excedem a um determinado tamanho que voltam a se desintegrar.

Para jatos de alta velocidade acredita-se que a ação do ar ambiente é a causa principal da atomização, embora a turbulência contribua significativamente em desorganizar a superfície do jato deixando-o mais suscetível a estes efeitos. Mas este conceito não é universalmente aceito. Concorda-se que um comprimento não perturbado deveria ser observado na saída do bico aspersor em função do tempo que uma onda de ar induzida necessita para se desenvolver, entretanto, a geometria do aspersor influencia significativamente (SILVA et. al., 2004).

SAZHIN et al. (2003) compararam três modelos de penetração do jato no estágio inicial do spray. No primeiro, a ruptura e o ar induzido não foram considerados; no segundo, somente o processo de ruptura foi considerado e, no terceiro, a ruptura e o ar induzido foram ambos considerados. Os autores afirmam que a indução de ar faz aumentar a penetração enquanto a ruptura a diminui e que, consequentemente, estes efeitos tendem a se compensar, porém não há uma ponderação da importância de cada um dos fenômenos na penetração do estágio inicial do spray. 
Alguns modelos empíricos foram formulados por GRANT E MIDDLEMAN (1966) e por MIESSE (1955) para ruptura de jatos turbulentos, respectivamente nas equações $4.1 \mathrm{e}$ 4.2. onde $d_{0}$ é o diâmetro do aspersor e $W e$ e Re são os adimensionais de Weber e Reynolds.

$$
\begin{aligned}
& L=8,51 d_{0} W e^{0,32} \\
& L=538 d_{0} W e R e^{-0,625}
\end{aligned}
$$

Em todo processo que envolveu este estudo, foram utilizados aspersores "vermelhos" (indicado na tabela 4.1). Estes aspersores têm diâmetro de furo de 0,02mm, aplicados a uma pressão de 800 PSI. Seguindo as equações acima, a distância de ruptura do jato, seria de 4,2 $x$ $10^{-3} \mathrm{~m}$ para a equação 4.1 e $7,1 \times 10^{-3} \mathrm{~m}$ para a equação 4.2 .

$\mathrm{Na}$ verdade, os aspersores utilizados pelos autores que formularam as equações acima eram muito diferentes dos aspersores da tabela 4.1, entretanto, temos uma referência interessante da distância de ruptura do jato, que nos cálculos formulados estariam entre 4 e 7 milímetros. Visualmente, como apresentado na figura 4.1, os aspersores utilizados em resfriamento de ambientes internos, a ruptura do jato ocorre no instante em que o líquido deixa o aspersor em função dos componentes radiais que geram a abertura do ângulo do spray.

No segundo estágio, temos a ruptura do líquido em gotas menores. Sob condições de equilíbrio, a pressão interna em qualquer ponto da superfície da gota, $\left(P_{l}\right)$ é suficiente para contrabalançar a pressão do ar externa $\left(P_{A}\right)$ e a pressão da tensão superficial $\left(P_{\sigma}\right)$, de modo que:

$$
P_{l}=P_{A}+P_{\sigma}=\text { cte }
$$

Como a gota é esférica, o valor da pressão da tensão superficial fica assim determinado:

$$
P_{\sigma}=\frac{4 \sigma}{D}
$$

onde $\sigma=$ tensão superficial $\left(\mathrm{kg} / \mathrm{s}^{2}\right)$ e $\mathrm{D}=$ diâmetro da gota $(\mathrm{m})$.

A gota só vai permanecer estável em sua geometria quando a variação da pressão do ar externo $\left(P_{A}\right)$ for compensada variando a pressão da tensão superficial $\left(P_{\sigma}\right)$ em proporção tal que a pressão interna $\left(P_{l}\right)$ permaneça constante. Em situações em que a pressão do ar $\left(P_{A}\right)$ 
for maior a ponto de não poder ser compensada pela pressão da tensão superficial $\left(P_{\sigma}\right)$, a gota vai sofrer uma deformação a ponto de reduzir a pressão da tensão superficial $\left(P_{\sigma}\right)$ até sua ruptura em gostas de menor diâmetro. Em uma gota menor o valor da pressão da tensão superficial pode ser suficientemente grande para que haja o equilíbrio. Caso contrário, os rompimentos em gotas menores vão acontecendo sucessivamente até que a pressão interna $\left(P_{l}\right)$ se estabilize naquele tamanho de gota.

No caso dos aspersores, a ruptura da gota que é lançada no ar a uma determinada velocidade que vai ser determinada pela pressão dinâmica, a tensão superficial e a viscosidade. Como o fluido é a água e, portanto, de viscosidade baixa, a ruptura da gota vai se dar pelas forças inerciais $\left(0,5 \rho_{a} V_{R}^{2}\right)$ e pelas forças de tensão superficial $(\sigma / D)$. Estas duas forças combinadas formam o número de $\operatorname{Weber}(W e)$.

$$
W e=\frac{\rho_{a} V_{R}^{2} D}{\sigma}
$$

$D=$ diâmetro da gota $(\mathrm{m}) ; \sigma=$ tensão superficial $\left(\mathrm{kg} / \mathrm{s}^{2}\right) ; V_{R}=$ velocidade relativa $(\mathrm{m} / \mathrm{s})$ e $\rho_{a}=$ densidade do ar $\left(\mathrm{kg} / \mathrm{m}^{3}\right)$.

Segundo LEFEBVRE (1989), a condição inicial para a ruptura da gota é alcançada quando o arrasto aerodinâmico é igual a força de tensão superficial, que nos remete a seguinte equação:

$$
C_{D} \frac{\pi D^{2}}{4} 0,5 \rho_{a} V_{R}^{2}=\pi D \sigma
$$

ou,

$$
\frac{\rho_{a} V_{R}^{2} D}{\sigma}=\frac{8}{C_{D}}
$$

resultando em:

$$
W e_{\text {crit }}=\frac{8}{C_{D}}
$$

A equação 4.8, que determina o número crítico de Weber, que estabelece o diâmetro máximo que uma gosta pode ter naquela velocidade e a velocidade máxima para tal tamanho de gota. Esses dois parâmetros podem ser extraídos da equação agora definida.

Segundo o fabricante do aspersor, nas condições de pressão e vazão correspondentes, estes aspersores vão produzir um tamanho de gota sempre menor que $50 \mu$. Para esse tamanho de gota, se fossemos extrair a velocidade crítica da equação 4.7, esta estaria em torno de 180 
$\mathrm{m} / \mathrm{s}$ e, a velocidade que temos para o aspersor de $0,2 \mathrm{~mm}$ de diâmetro é por volta de $40 \mathrm{~m} / \mathrm{s}$. Isto significa que as gotas produzidas pelo aspersor utilizado estão já na condição de “estáveis” e podemos considera-las como gotas esféricas.

\subsection{Caracterização do Spray}

\subsubsection{Velocidade de saída do jato no aspersor}

SOMMERFELD E QIU (1998) elaboraram um detalhado estudo experimental de medição das principais características do spray, utilizando-se de PDA (Phase-Doppler Anemometry) para obter a variação do tamanho da gota no campo do fluxo e para medir a correlação tamanho-velocidade das gotas. As medições foram feitas para diversas condições de taxa de fluxo de ar, temperatura do ar e taxa de fluxo de líquido. Estes autores utilizaram em seus experimentos o álcool isopropílico, devido a sua alta taxa de evaporação, e o principal objetivo do estudo experimental era gerar dados para validação de simulações numéricas.

A partir da equação de Bernoulli, a velocidade de entrada $\left(V_{l_{0}}\right)$ para um aspersor de pressão pode ser definida como:

$$
V_{l_{0}}=C_{d} \sqrt{\frac{2 \Delta P_{l}}{\rho_{l}}}
$$

onde $\Delta P_{l}=$ diferença de pressão $P_{A}, \rho_{l}=$ densidade do líquido $\left(\frac{\mathrm{kg}}{\mathrm{m}^{3}}\right)$ e $C_{d}=$ coeficiente de descarga, cujo valor apresenta grande incerteza na bibliografia, assumindo valores arbitrários. Adotando o valor de 0,39 , estabelecido por Lefebvre (1989), para $\Delta P_{l}=5515840 \mathrm{~Pa}$ (800 PSI), $V_{l_{0}}=41 \mathrm{~m} / \mathrm{s}$.

Por outro lado, sendo conhecida a vazão de líquido e o diâmetro do aspersor a velocidade poderia ser calculada pela expressão:

$$
V_{l_{0}}=\frac{Q_{l}}{A_{0}}
$$


onde $Q_{l}=$ vazão de líquido $\mathrm{m}^{3} / \mathrm{s}, A_{0}=$ área do orifício de descarga $\left(\mathrm{m}^{2}\right)$ e $V_{l_{0}}=$ velocidade do líquido no orifício de descarga $(\mathrm{m} / \mathrm{s})$. No caso, para o aspersor utilizado, a vazão é de 0,066 LPM no diâmetro de $0,2 \mathrm{~mm}$ (dados da tabela 4.1), teríamos uma $V_{l_{0}}=35 \mathrm{~m} / \mathrm{s}$. Essa condição indica que o valor do coeficiente de descarga adotado por Lefebvre (1989) está dentro do esperado.

Entretanto, segundo LEFEBVRE (1989), em atomizadores de pressão nem toda a seção do aspersor é utilizada para o fluxo da massa líquida, dependendo da relação das dimensões internas do aspersor. Disso resulta que a área efetiva do aspersor seria ligeiramente menor do que sua área nominal. Consequentemente, para manter a vazão constante, há uma compensação no aumento da velocidade do líquido na saída do aspersor. A área efetiva $\left(\mathrm{m}^{2}\right)$ de um atomizador de pressão é usualmente descrita em termos de número de fluxo $(F N)$, o qual se expressa como:

$$
F N=\frac{\dot{\mathrm{m}}}{\left(\Delta P_{L} \rho_{l}\right)^{0,5}}=C_{d} A_{e f} \sqrt{2}
$$

onde $\dot{\mathrm{m}}=$ fluxo de massa de líquido $\mathrm{kg} / \mathrm{s}, \Delta P_{L}=$ diferença de pressão $\left(P_{A}\right), A_{e f}=$ área efetiva $\left(\mathrm{m}^{2}\right), \rho_{l}=$ densidade do líquido $\mathrm{kg} / \mathrm{m}^{3}$. Desta forma, a Equação 4.10 deve ser reescrita como:

$$
V_{l_{0}}=\frac{Q_{l} C_{d} \sqrt{2}}{F N}
$$

O valor de $C_{d}$ que estamos adotando com base é de 0,39 (LEFEBVRE, 1989) e o valor de $F N$ calculado é de $1,48 \times 10^{-8}$ e $1,73 \times 10^{-8}$, para a equação 4.11 , a velocidade do líquido no orifício fica em $41 \mathrm{~m} / \mathrm{s}$ e $35 \mathrm{~m} / \mathrm{s}$, respectivamente. Nesse caso, foi adotado como parâmetro de velocidade, $35 \mathrm{~m} / \mathrm{s}$. 


\subsubsection{Tamanho médio das gotas geradas no aspersor}

Um mesmo atomizador pode gerar gotas de diversos tamanhos. Na prática os aspersores não produzem sprays de tamanhos de gotas uniformes.

LEFEBVRE (1989) orienta a obtenção de um gráfico de distribuição de tamanho de gotas através de um histograma que relaciona o tamanho de gotas e número de gotas cujas dimensões ficam entre os limites $D-\Delta D / 2$ e $D+\Delta D / 2$. Quanto menor $\Delta D$, mais o histograma se aproxima de uma curva de frequência que pode ser considerada como característica do spray e comumente denominada de curva de distribuição de frequência.

A empresa Environmental Engineering Concepts Inc. propôs uma curva de distribuição de frequência de tamanho de gotas de um aspersor utilizado em resfriamento evaporativo, que especifica gotas de $10 \mu \mathrm{m}$ (EEC, 2005). Os dados obtidos estão listados na tabela na curva de distribuição, a seguir, na tabela 4.2 e figura 4.3:

Tabela 4.2 - Distribuição de tamanho de gotas de um aspersor de $0,2 \mathrm{~mm}$

\begin{tabular}{c|c}
\hline Diâmetro Médio $(\mu \mathrm{m})$ & Percentagem \% \\
\hline 0,75 & 0,05 \\
\hline 1,5 & 0,2 \\
\hline 2,75 & 1,81 \\
\hline 4,25 & 9,78 \\
\hline 6,25 & 24,66 \\
\hline 8,75 & 30,17 \\
\hline 12,5 & 28,83 \\
\hline 15 & 4,49 \\
\hline
\end{tabular}

Fonte: EEC, 2005

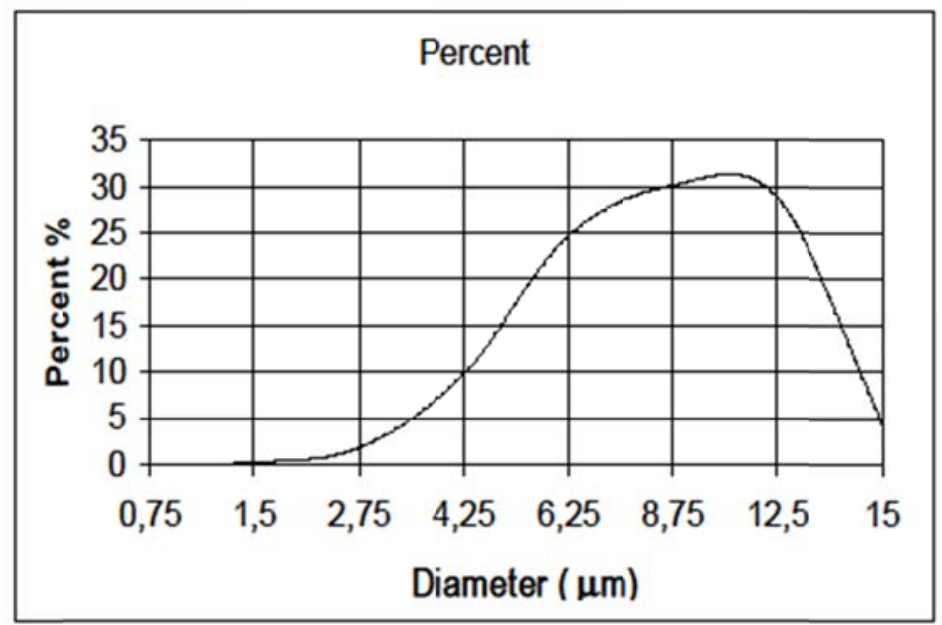


Figura 4.3 - Curva de distribuição de frequência de tamanho de gotas de um aspersor de $0,2 \mathrm{~mm}$ de diâmetro

Fonte: EEC, 2005

A partir desta curva de frequência, pode-se obter um valor médio representativo do spray. Segundo LEFEBVRE (1989), o conceito de diâmetro médio tem sido generalizado e sua notação padronizada resultou na seguinte equação geral:

$$
D_{a b}=\left[\frac{\sum N_{i} D_{i}^{a}}{\sum N_{i} D_{i}^{b}}\right]^{\frac{1}{(a-b)}}
$$

onde $a$ e $b$ podem assumir qualquer valor correspondente ao efeito investigado, a soma $a+b$ é denominada ordem do diâmetro médio, $i$ denota a escala de tamanho considerado, $N i$ é o número de gotas na escala de tamanho $i$, e $D i$ é o diâmetro médio da escala de tamanho $i$. Na Tabela 4.3 são listados os cálculos de diâmetro médio e suas respectivas áreas de aplicação.

Tabela 4.3 - Diâmetros médios das gotas e suas aplicações

\begin{tabular}{|c|c|c|c|c|c|c|}
\hline$a$ & $b$ & $\begin{array}{l}a+b \\
\text { (order) }\end{array}$ & Symbol & $\begin{array}{l}\text { Name of mean } \\
\text { diameter }\end{array}$ & Expression & Application \\
\hline 1 & 0 & 1 & $D_{n 0}$ & Length & $\frac{\sum N D_{i}}{\sum N_{t}}$ & Comparisons \\
\hline 2 & 0 & 2 & $D_{x}$ & Surface area & $\left(\frac{\sum N D_{i}^{z}}{\sum N_{t}}\right)^{n}$ & $\begin{array}{l}\text { Surface area } \\
\text { controlling }\end{array}$ \\
\hline 3 & 0 & 3 & $D_{90}$ & Volume & $\left(\frac{\sum N_{t} D_{t}^{\prime}}{\sum N_{t}}\right)^{n}$ & $\begin{array}{l}\text { Volume controlling, } \\
\text { e.g., hydrology }\end{array}$ \\
\hline 2 & 1 & 3 & $D_{2 u}$ & Surface area-length & $\frac{\sum N D_{i}^{2}}{\sum N D_{i}}$ & Absorption \\
\hline 3 & 1 & 4 & $D_{n}$ & Volume-length & $\left(\frac{\sum N D_{t}^{\prime}}{\sum N D_{i}}\right)^{n}$ & $\begin{array}{l}\text { Evaporation, } \\
\text { molecular diffusion }\end{array}$ \\
\hline 3 & 2 & 5 & $D_{n 2}$ & Sauter (SMD) & $\frac{\sum N_{l} D_{i}^{\prime}}{\sum N_{l} D_{i}^{2}}$ & $\begin{array}{l}\text { Mass transfer, } \\
\text { reaction }\end{array}$ \\
\hline 4 & 3 & 7 & $D_{s}$ & $\begin{array}{l}\text { De Brouckere or } \\
\text { Herdan }\end{array}$ & $\frac{\sum N_{i} D_{i}^{4}}{\sum N_{i} D_{i}^{\prime}}$ & $\begin{array}{l}\text { Combustion } \\
\text { equilibrium }\end{array}$ \\
\hline
\end{tabular}

Fonte: LEFEBVRE, 1989

O SMD (Sauter Mean Diameter), que é o diâmetro da gota cuja relação entre o volume e a área de superfície, apresenta-se como o mais adequado em aplicações de transferência de massa em sprays. Destacando a equação, temos:

$$
D_{32}=\frac{\sum N_{i} D_{i}^{3}}{\sum N_{i} D_{i}^{2}}
$$


Aplicando-se o SMD nos dados observados na Tabela 4.3, obtém-se um diâmetro médio de 10,97 mm, ou seja, $11 \mathrm{~mm}$.

O ângulo do cone o qual essas gotas são formadas está definido pelo fabricante. No caso do aspersor de $0,2 \mathrm{~mm}$ de diâmetro de orifício, trabalhando com 800 PSI de pressão forma um cone de aproximadamente $55^{\circ}$ a $70^{\circ}$, como resultado da interação entre o ar e o spray.

Normalmente, ângulo do spray é formado pelas duas linhas retas traçadas do orifício de descarga, tangenciando os contornos do spray, a uma distância específica da face do atomizador (LEFEBVRE, 1989). O ângulo obtido através de uma projeção do spray em tela foi de $60^{\circ}$

\subsection{Penetração e Dispersão das Gotas}

A penetração de um spray pode ser definida como a máxima distância que ele alcança quando aspergido em um ar parado. Consequentemente, as forças atuantes na penetração são a energia cinética inicial do jato de líquido e a resistência do ar ambiente. A energia cinética do jato, geralmente alta, é gradualmente dissipada pela resistência que o ar impõe. A medida que a atomização ocorre, a superfície do spray aumenta e as gotas dissipam sua energia cinética. Atuam nas gotas a gravidade e o movimento do ar que as carrega.

Em geral, um spray estreito terá maior penetração, enquanto um spray aberto e bem atomizado, devido à maior resistência do ar, terá menor penetração. Em todos os casos, a penetração do spray é muito maior do que a penetração de uma gota isolada. As primeiras gotas a serem formadas transferem energia ao ar ambiente, o qual entra em movimento junto com o spray. Assim sendo, o ar oferece menor resistência às gotas seguintes, que consequentemente penetram mais.

Em trabalho recente, SHARMA et al. (2001) apresentam um estudo sobre a influência dos parâmetros do spray na penetração e vaporização de gotas de óleo. O autor constatou que os fatores de maior influência na penetração são o ângulo do spray e a pressão do ar na câmara de combustão. 
O alcance do spray é determinado em função da evaporação total das gotas. Desta forma, a penetração do spray é determinada pela distância onde ocorre a total evaporação e a névoa não mais se torna visível.

A dispersão, por sua vez, pode ser expressa quantitativamente como a razão entre o volume total do spray e o volume de líquido contido nele. Como consequência de uma boa dispersão o líquido se mistura mais rapidamente com o ar ambiente, determinando a taxa de evaporação.

A questão principal relacionada a penetração e a dispersão é a possibilidade de se avaliar a taxa de evaporação e, por essa análise, estabelecer os critérios para que a evaporação ocorra o mais rápido possível. Quanto mais rápido a dissipação ocorrer, mais rápida evaporação ocorre. Essa característica é influenciada diretamente pela umidade relativa do ar ambiente.

Dessa forma, a avaliação criteriosa dos parâmetros físicos como a energia cinética do fluido, tamanho de gota, umidade relativa e temperaturas do ar e do fluido, são os fatores que vão interferir diretamente na taxa de evaporação, junto com as propriedades termodinâmicas envolvidas no processo evaporativo. A análise recai sobre que taxa de evaporação que se necessita para obter os resultados de conforto térmico desejados.

\subsection{Propriedades Termodinâmicas}

A função do sistema de atomização da água é obter da forma mais eficiente possível a evaporação da água aspergida no ambiente que, por sua vez, irá trazer os resultados de umidade e temperatura consequentes. Dessa forma, as propriedades termodinâmicas que traduzem o processo de evaporação nas condições que que esta evaporação ocorre são as que devem estar definidas. Sendo assim, as propriedades que refletem essa condição são a pressão de vapor e a entalpia de vaporização da água.

Estudos demonstram que a curvatura de uma gota faz com que a pressão de vapor seja maior do que em uma superfície plana, favorecendo a evaporação. Este aumento de pressão seria acompanhado de aumento de entalpia, entretanto este aumento é tão pequeno que o aumento de temperatura se torna desprezível (ASHRAE, 1996). Devido a esta pequena 
influência, FAETH (1977) descarta os efeitos da tensão superficial na pressão de vapor para pressões maiores do que $1 \mathrm{~atm}$ e gotas maiores do que $1 \mu \mathrm{m}$.

Sendo as gotas constituídas unicamente de água, o comportamento termodinâmico destas é o mesmo da água líquida. A entalpia da mistura é a soma da entalpia do ar saturado e a entalpia do líquido contido na mistura.

$\mathrm{Na}$ evaporação da água, ou seja, a mudança de fase de líquido a vapor, os potenciais químicos das fases $\alpha$ (líquido) e $\beta$ (vapor) são funções da temperatura $T$ e a pressão $P$ e tem o mesmo valor:

$$
\mu_{\alpha}(T, P)=\mu_{\beta}(T, P)
$$

A partir desta igualdade e empregando relações termodinâmicas, obtemos a equação de Clapeyron, indicada na figura 4.4, a seguir:

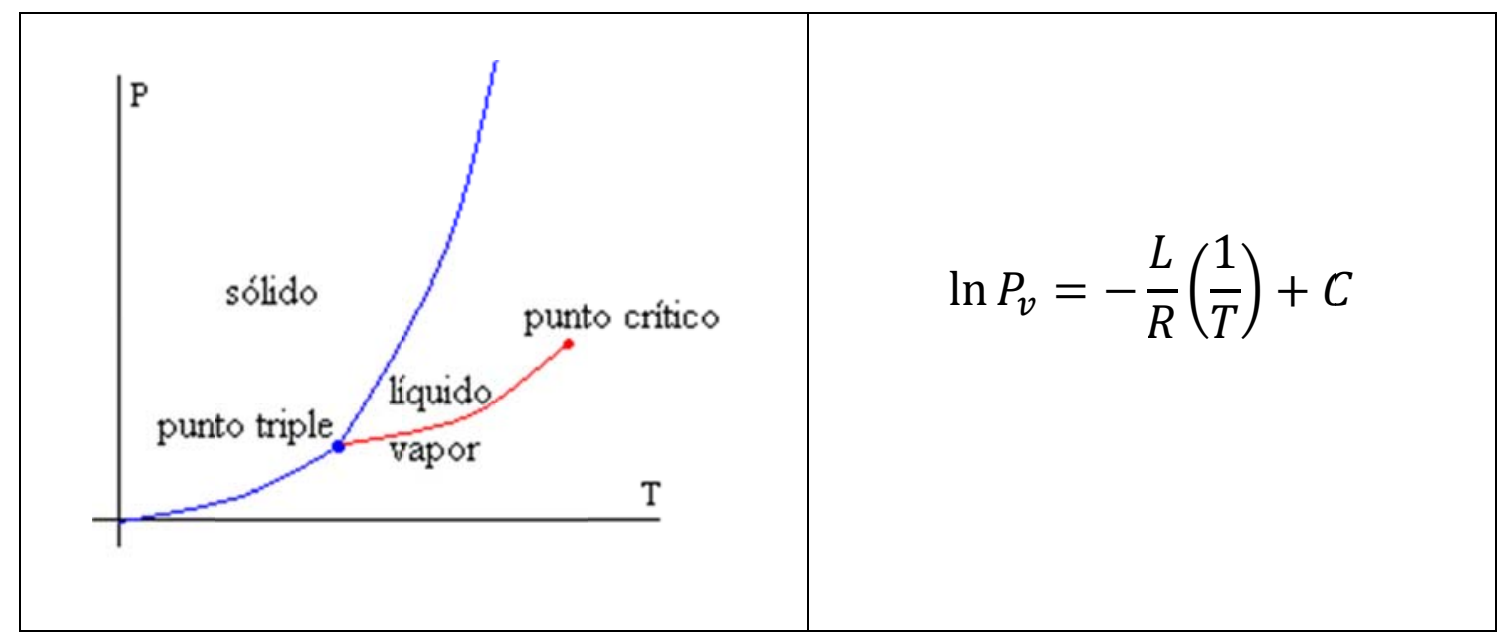

Figura 4.4 - Equação de Clausius Clapeyron para pressão de vapor Fonte: http://www.sc.ehu.es/sbweb/ - Acesso em 16/04/2016

Supondo que a fase vapor é um gás ideal e que o volume mollar do líquido é desprezível comparado com o volume molar do gás, chegamos a denominada equação de Clausius-Clapeyron que nos proporciona a pressão de vapor da água $P_{\boldsymbol{v}}$ em função da 
temperatura $T$, supondo além disso, que a entalpia $L$ de vaporização é independente da temperatura (ao menos em um determinado intervalo).

\subsubsection{Mecanismo da vaporização}

Partindo da primeira lei da termodinâmica, onde, $\Delta U=Q-W$ sendo $Q$ o calor absorvido $(Q>0)$ pelo sistema e $W$ o trabalho realizado pelo sistema ( $W>0$ se o sistema aumenta seu volume), suponhamos que uma quantidade de calor $Q=L_{i}$ converte um mol de líquido em um mol de vapor sem mudar de volume, então:

$$
\Delta U=Q+L_{i}
$$

No entanto, durante o processo de vaporização há uma variação de volume, um mol de líquido $V_{l}$ ocupa menos volume que um mol de vapor $V_{v}$, a mesma pressão $P$ e temperatura T. O trabalho realizado pelo sistema é:

$$
W=P\left(V_{v}-V_{i}\right)
$$

O calor que temos que fornecer, é:

$$
Q=L=\Delta U+W=L_{i}+P\left(V_{v}-V_{i}\right)
$$

O valor de $L$ se define como o calor latente ou entalpia de vaporização, logo, o calor necessário para que se evapore um mol de líquido a uma pressão constante $P$ e a temperatura $T$, ou seja, o calor que deve ser retirado do ar para que a água se evapore. 
LEE E TANKIN (1984) propuseram um modelo analítico para descrever o comportamento de um spray cônico vazado, abordando a lâmina de água antes do rompimento e a porção de gotas resultante do rompimento. Embora o trabalho apresente um modelo bidimensional de velocidades e considere uma distribuição de tamanho de gotas, não aborda as trocas de calor e massa entre o ar e as gotas, que são consideradas de diâmetro constante. $\mathrm{O}$ modelo trata exclusivamente do escoamento do ar e das gotas e, segundo os autores, tem boa concordância com os experimentos.

Com aplicação em spray drying, ZBICINSKI (1995) propôs um modelo matemático de transferência de momento, calor e massa na zona de atomização fundamentado no balanço dos processos de transporte entre as fases contínua e dispersa. O modelo, que considerava a distribuição irregular de partículas e os efeitos de indução de ar, foi comparado com dados experimentais obtidos em um túnel de vento, no qual ocorre a secagem numa temperatura em torno de $200^{\circ} \mathrm{C}$. A modelagem do fluxo de ar no secador foi obtida teoricamente a partir de programa de CFD. No entanto, o processo de indução de ar, resultado do aumento da seção transversal do escoamento, é calculado em função do campo de velocidades da câmara de secagem, determinado pelo CFD. Os resultados muito se aproximaram das simulações de sprays com modelos de fonte de partícula na célula (particle-source-in-cell, PSI-cell), no qual as equações de continuidade e de Navier-Stokes são resolvidas tratando a gota como fonte de massa, momento e energia para a fase gasosa (CROWE et al., 1977).

KACHHWAHA et al. (1998) é outra referência que atenta explicitamente para o desenvolvimento de simulação numérica de spray de água no que se refere à conservação da massa, energia e quantidade de movimento. Em seu trabalho, foi desenvolvido um modelo numérico bi-dimensional para simular um spray horizontal inserido em um túnel de vento, do qual foram obtidas as condições do ar (temperatura e umidade) ao longo do duto e as diferentes trajetórias das gotas com seus históricos de temperatura. Os resultados foram comparados com estudos experimentais com boa correlação.

$\mathrm{Na}$ prática, a aplicação de sprays diretamente no ambiente, como é o caso das instalações em que se pretende promover alterações das características de temperatura e umidade, a favor de uma condição de conforto térmico mais adequada tanto as atividades, quanto as pessoas, gera, por consequência, umidades imprevisíveis devido a ausência de 
alguns parâmetros de controle do processo que interferem no potencial de resfriamento possível.

A temperatura interna nos locais de instalação condicionados por resfriamento evaporativo depende do fluxo de ar resfriado, da qualidade térmica do local. Características próprias construtivas e de layout e as atividades produtivas ali desenvolvidas interferem significativamente no fluxo de ar interno e na carga térmica, criando setores diferenciados dentro do mesmo ambiente.

Assim, algumas aplicações, frente a condições características de instalação, modificam a eficiência do processo evaporativo. Os objetivos deste trabalho não focam o mecanismo de formação do spray, resultante da geometria interna do aspersor, mas especificamente o seu comportamento após formado. Independentemente do tipo de atomizador, o principal objetivo dos sprays é incrementar a área superficial do líquido aspergido, assim, melhorar as taxas de troca de calor e massa deste com o ambiente, a favor da evaporação.

Determinar os padrões de projeto que permitem controlar as variáveis que estabelecem a condição térmica resultante e, como consequência, na aplicabilidade de sistemas de resfriamento evaporativo é o foco desse estudo. Representar o comportamento de um equipamento que utiliza o resfriamento evaporativo em condições reais depende, inicialmente um modelo matemático baseado em equações que representam os fenómenos físicos que ocorrem nos processos de resfriamento. Estas equações têm como base o cálculo de transferência de calor e massa, e o balanço de massa e energia do processo evaporativo.

Para simplificar a análise da transferência de calor e massa, considerou-se que o ar seco e o vapor de água têm um comportamento de gás ideal e o ar é uma mistura de dois gases (ar seco e vapor de água), designado por ar úmido. Considera-se um processo adiabático, ou seja, as perdas de calor para o ambiente são desprezáveis e o sistema em regime permanente. As variações de energia cinética e potencial não são consideradas e a água do sistema está continuamente em recirculação. Essas considerações são feitas para que, na base de cálculo, a temperatura da área climatizada seja próxima da temperatura de bulbo úmido do ar ambiente (o máximo de eficiência). 


\subsection{Modelos Empregados no Estudo dos Sprays}

FAETH (1983) classifica os modelos para sprays em duas grandes categorias:

a) Modelos de Fluxo Localmente Homogêneos (FLH): nos quais ar e gota são admitidos em equilíbrio dinâmico e termodinâmico. Aplicável para spray composto de gotas infinitamente pequenas.

b) Modelos de Fluxo Separados (FS): nos quais são considerados os efeitos de transferência finita de quantidade de movimento, calor e massa entre as fases.

Nos modelos FLH, considera-se que velocidade e temperatura de cada uma das fases se mantenham em equilíbrio em todos os pontos do fluxo. Esta afirmativa será quantitativamente mais correta quanto menor for o tamanho das gotas. Os modelos FLH podem produzir bons resultados para o uso dos sprays no caso de uma atomização com densidade numérica máxima do diâmetro das gotas entre 10 e $20 \mu \mathrm{m}$.

No que diz respeito aos modelos de fluxo separados (FS), FAETH (1983) descreve que os modelos atuais calculam a média, geralmente, sobre os processos que ocorrem nas escalas comparáveis ao tamanho da gota. Existem três linhas de tratamento do problema:

- A primeira, aplicada na maioria das análises de modelos de fluxos separados (FS) para evaporação de sprays, denomina-se modelo de partículas discretas, no qual o spray é dividido em amostras de gotas discretas, cujo movimento e transporte são rastreados ao longo do campo de fluxo. Este modelo é bastante apropriado quando o diâmetro das gotas é muito menor do que o espaço entre elas. Entretanto este modelo se torna inapropriado para sprays densos, sendo sugerido, para uma solução mais detalhada, utilizando as equações de Navier-Stokes.

- A segunda linha de tratamento de modelos FS é definida como modelo contínuo de gotas. Neste caso, as propriedades das gotas são representadas por uma função estatística de distribuição que define em um espaço multidimensional do diâmetro da gota, posição, tempo, velocidade, temperatura, concentração, etc. Os princípios de conservação fornecem uma equação do transporte para a função de distribuição, que é resolvida em conjunto com as equações de conservação de energia, para abranger todas as propriedades do spray. 
- O último método de tratamento emprega o modelo de formulação contínua das equações de conservação de ambas as fases. Os movimentos de gotas e ar são tratados como se fossem meios contínuos Inter penetrantes. Nesta formulação, as equações governantes são similares para ambas as fases. Para sprays, entretanto, múltiplas fases devem ser consideradas baseadas em campos de tamanhos de gotas.

Frente às características dos modelos acima pode-se fazer o seguinte quadro resumo:

\begin{tabular}{|l|l|}
\hline Modelo FLH & $\begin{array}{l}\text { Poderia ser utilizado, porém é } \\
\text { demasiadamente simplificado e tem } \\
\text { utilização limitada a gotas menores do } \\
\text { que } 20 \mu \mathrm{m} .\end{array}$ \\
\hline Modelos FS & $\begin{array}{l}\text { Partículas discretas: pode ser utilizado } \\
\text { se o spray for considerado diluído; } \\
\text { Modelo contínuo de gotas: apropriado } \\
\text { para spray não evaporativo, que não é } \\
\text { caso atual; } \\
\text { Modelo de formulação contínua: } \\
\text { adequado para problemas de uma só fase } \\
\text { e complexo para casos multifase, que é o } \\
\text { caso atual. }\end{array}$ \\
\hline
\end{tabular}

Se considerarmos o spray diluído, no qual as possibilidades de colisão e coalescência de gotas sejam pequenas, se faz as seguintes observações:

1) A consideração da possibilidade de colisão e coalescência das gotas é importante na região perto do aspersor, onde o jato é mais denso. Entretanto, consideramos o spray constituído a partir da estabilidade das gotas, o que acontece a determinada distância do aspersor.

2) O spray está em escoamento livre, cuja sua configuração cônica, devido ao ingresso de ar ambiente, tende a afastar as gotas uma das outras. 
3) O fato de todas as gotas possuírem o mesmo tamanho impossibilita que gotas menores sejam arrastadas para o interior do spray com o ar induzido, diminuindo a possibilidade de colisão.

4) $\mathrm{O}$ efeito da evaporação reduz o diâmetro das gotas à medida que a seção do spray aumenta.

5) Soma-se a isso que o valor da fração de volume (a) calculado para uma distância de 0,001 $\mathrm{m}$ de um aspersor de $0,2 \mathrm{~mm}$ de diâmetro, semiângulo de $30^{\circ}$ e vazão de $5,64 l / h$ é da ordem de $1,8 \%$ e que tende a diminuir em função da trajetória e evaporação das gotas.

Uma conclusão geral obtida através de diversos estudos é que há pequena probabilidade de colisão de gotas em spray quando estas se movem em direção paralela ou ao longo de caminhos divergentes. A estabilidade das gotas em corrente linear e as forças repulsivas de sustentação de gotas próximas, movendo-se em paralelo, confirmam esta conclusão (SIRIGNANO, 1999).

Assim, considerando que o spray seja diluído e que a possibilidade de colisão e coalescência das gotas seja desprezível, adota-se o modelo de partículas discretas em fluxos separados.

O resultado da aplicabilidade de um sistema de resfriamento evaporativo é de promover alterações nas características ambientais internas, referentes a temperatura e umidade relativa, de tal forma que a nova condição térmica esteja adequada ou integrada as necessidades que este ambiente assim exige. O nível de eficiência do processo evaporativo é tanto maior quanto mais próxima for a temperatura que conseguimos atingir no ambiente (bulbo seco) da temperatura de bulbo úmido do ar admitido. Dessa forma analisar os fatores que interferem no processo evaporativo é básico do modelo dimensional que se busca.

A eficiência processo de evaporação sofre interferências tanto do spray quanto das condições termodinâmicas e as características da edificação do local de instalação. Podemos partir do princípio de avaliação dessas interferências no processo de evaporação ocasionadas (1) pela dinâmica da atomização, (2) pelas propriedades de transferência de calor e massa da fase contínua, (3) o estudo da evaporação do spray e (4) pelas características da edificação. 


\subsection{Dinâmica da Atomização}

Um dos passos mais importantes na simulação de um spray é a relação dinâmica entre as gostas do spray e o ar ambiente, ou seja, quantificação da movimentação do ar arrastado pelo deslocamento da fase líquida do jato. Essa quantificação traduz a interferência do spray nas trocas de calor e massa das gotas com o ar, além da correta quantificação das velocidades e distâncias alcançadas pelo jato.

MURAKAMI et al. (1992) analisou o comportamento de partículas, com densidade de $1050 \mathrm{~kg} / \mathrm{m}^{3}$, transportadas pelo ar e constatou que partículas até cerca de $10 \mu \mathrm{m}$ de diâmetro movem-se exatamente como o fluxo de ar. Apenas partículas maiores do que $50 \mu \mathrm{m}$ devem obrigatoriamente ter a gravidade considerada.

É importante detalhar a origem da indução de ar gerada pela movimentação das gotas produzidas afim de que seja possível prever a velocidade com que o ar induzido penetra as gotas, no sentido axial do eixo, e sua relação com a pressão aplicada no spray.

SILVA et. al. (2004) diz que a água aspergida em um ambiente induz a uma troca de momento entre as gotas do spray e o ar, representado na figura 5.1. As gotas desaceleram devido ao arrasto aerodinâmico e o momento cedido pelas gotas é adquirido pelo ar. Isso cria um campo de fluxo no qual o ar é continuamente arrastado para dentro do spray. Durante este processo, o ar é induzido a entrar no spray, carrega as gotas menores da periferia do spray para o interior deste, causando uma eventual contração do spray, A magnitude da contração depende da força de indução do ar e da força necessária para tirar as gotas de sua trajetória original. A magnitude da contração depende diretamente da razão de fluxo total, do tamanho e da velocidade de entrada das gotas e da densidade e viscosidade do ar (GHOSH e HUNT, 1994).

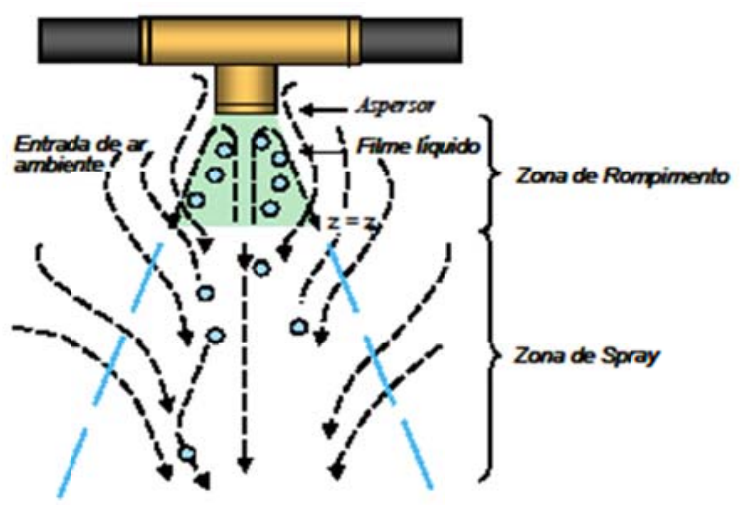

Figura 5.1 - Esquema das zonas e do rompimento do filme líquido de um spray típico Fonte: SILVA et.al., 2004 
Para entender a velocidade do ar induzido pelo momento do spray inicialmente devese considerar uma gota de raio $a$ em movimento através do ar. As gotas que entram no fluxo deslocam o ar para frente, simplesmente como resultado do fluxo de ar em torno delas, numa quantidade que é da ordem do volume da gota no fluxo de ar (SILVA et. al.,2004).

Em jatos de Spray a turbulência arrasta o fluxo externo com ele e, portanto, o volume do fluxo de ar no spray aumenta, o que implica que o ar externo é induzido para o interior do spray pelo seu perímetro. A figura 5.2 nos mostra que, inicialmente, a velocidade das gotas é muito maior do que a da corrente de ar e, desta forma, não é muito afetada, mas subsequentemente elas reduzem sua velocidade tornando-se comparáveis à velocidade do ar (zona II). Eventualmente a velocidade do ar decresce tanto que se torna menor do que a velocidade terminal (zona III).

Cabe salientar que GHOSH e HUNT (1994) consideram que o spray é efetivamente formado, após o rompimento do filme-líquido em gotas estáveis.
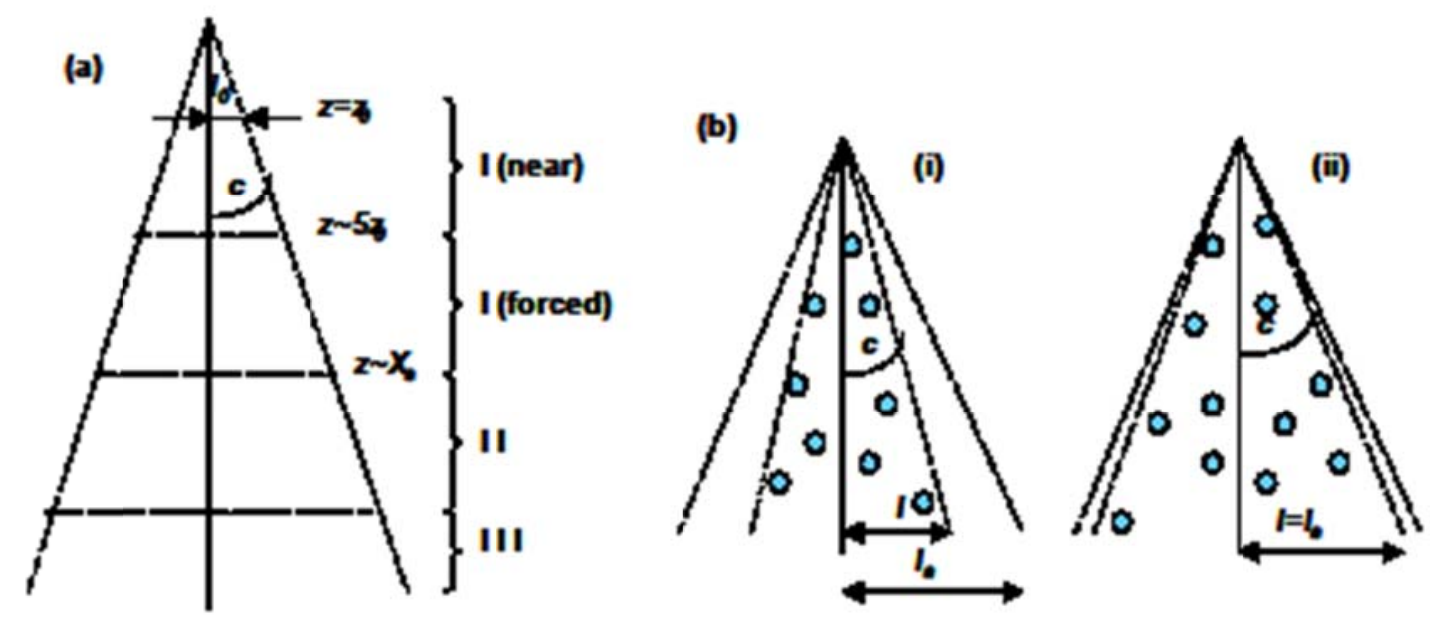

Figura 5.2 - (a) Principais zonas num spray vertical. (b) Defiinição de perfil para spray estreito (i) e aberto (ii)

Fonte: SILVA et. al., 2004

Segundo SILVA et. al. (2004) A caracterização das zonas verticais do spray, pode ser definida, como segue:

- Zona I (near): a velocidade da água é a tão grande $\left(V_{l} \gg V_{a}\right)$ e a quantidade de ar tão pequena $\left(l_{a}=l_{0}\right)$ que este não consegue frear o líquido e, consequentemente, as velocidades das gotas $\left(V_{l}=V_{l_{0}}\right)$ e do $\operatorname{ar}\left(V_{a}=b, V_{l_{0}}\right)$ são muito próximas à velocidade de entrada do líquido $\left(V_{l_{0}}\right)$, sendo que $b<1$. 
- Zona I (forced): a quantidade de ar no spray aumenta reduzindo as velocidades das gotas e do ar que havia sido acelerado na subzona anterior. As reduções de $V_{a}$ e $V_{l}$ são bastante bruscas, sendo que a quantidade de movimento é compensada com o aumento de $l_{a}$ e $l$ (raio do jato de ar e raio do jato de spray, respectivamente).

- Zona II: muito embora $V_{l} \gg V_{a}$, o volume de ar no spray é tão grande que as gotas já não mais determinam o escoamento do ar. Neste momento, há um desacoplamento entre o comportamento do ar e das gotas, ou seja, os escoamentos de ar e de gotas tornam-se independentes.

- Zona III: nesta zona as gotas atingem sua velocidade terminal $\left(V_{l}=V_{t}\right)$ e o ar tende a ter a mesma velocidade das gotas ou, eventualmente, até menor $\left(V_{l} \geq V_{a}\right)$.

Através de uma análise unidimensional, proposta por SILVA et. al. (2004), é possível calcular a variação da largura do jato de ar $\left.l_{a}\right)$ e a velocidade axial média do ar $\left(V_{a}\right)$, em função da distância $z$ na zona do spray. Na zona inicial de rompimento das gotas há uma grande componente de fluxo de ar normal ao eixo do jato. Entretanto, abaixo da altura $z=z_{0}$ a qual define o início da zona de spray, o fluxo de ar que ingressa no spray é amplamente axial, e a velocidade radial de arraste é pequena comparada à velocidade do ar dentro do jato.

A vazão de líquido $\left(Q_{l}\right)$ que sai do aspersor distribui gotas esféricas no nível $z=z_{0}$, onde o raio médio do spray é $l_{0}$. Estas gotas têm velocidade de entrada $V_{l_{0}}$ e ocupam uma fração de volume $\alpha_{0}$ do volume do spray. Observações de sprays demonstram que estas gotas aspergidas estão contidas numa área $A(z)$. Desta forma, o raio médio $l(z)$ é definido por:

$$
A=\pi l^{2}
$$

As gotas aspergidas com alta velocidade, inicialmente viajam em linha reta. Portanto, se for escolhido um sistema de coordenadas no qual $l=l_{0}$ para $z=z_{0}$, onde $z=l_{0} / c$, segue que:

$$
l=l_{0}+c\left(z-z_{0}\right)=c z
$$

sendo c a tangente do semiângulo do spray. 
Em consequência da indução na fronteira do jato de ar, a largura $l_{a}$ do jato de ar pode ser significativamente maior do que a largura $l$ do jato de spray, como pode ser verificado na Figura 5.3. GHOSH E HUNT (1994) assumem que esta indução é similar ao que ocorre em um jato turbulento e, portanto, proporcional à velocidade média do jato de ar. A partir do balanço de massa ao longo do spray:

$$
\frac{d}{d z} l_{a}^{2} V_{a}=2 \beta l_{a} V_{a}
$$

Para $l_{a} \gg l$ e $z>z_{0}$, onde $\beta$ é o coeficiente de indução calculado em função da velocidade média, cujo valor 0,11, segundo GHOSH E HUNT, (1994), é o apropriado para um jato típico.

Entretanto, para sprays abertos $(c \gg \beta)$ a largura do fluxo de ar não é determinada pela expansão turbulenta do jato de ar, mas pelo próprio aspersor, sendo que $l_{a}=l$, consequentemente, para se calcular a taxa de variação de vazão para sprays abertos a equação 5.3 é substituída por:

$$
\frac{d}{d z} l_{a}^{2} V_{a}=\frac{d}{d z} l^{2} V_{a}
$$

Assumindo formalmente que $c \ll 1$, tal que as componentes axiais das velocidades do ar e do líquido são muito maiores do que as componentes radiais.

Multiplicando-se ambos os lados da equação por $\pi d z$, a equação 5.4 pode ser reescrita, assim:

$$
d\left(\pi l_{a}^{2} V_{a}\right)=2 \pi l_{a} \beta V_{a} d z
$$

e interpretada como o fluxo de ar que entra pela lateral do spray, de área $2 \pi l_{a} d z$, com velocidade $\beta V_{a}$, sendo igual à variação do fluxo de ar que passa pela área $\pi l_{a}^{2}$, com velocidade $V_{a}$. 

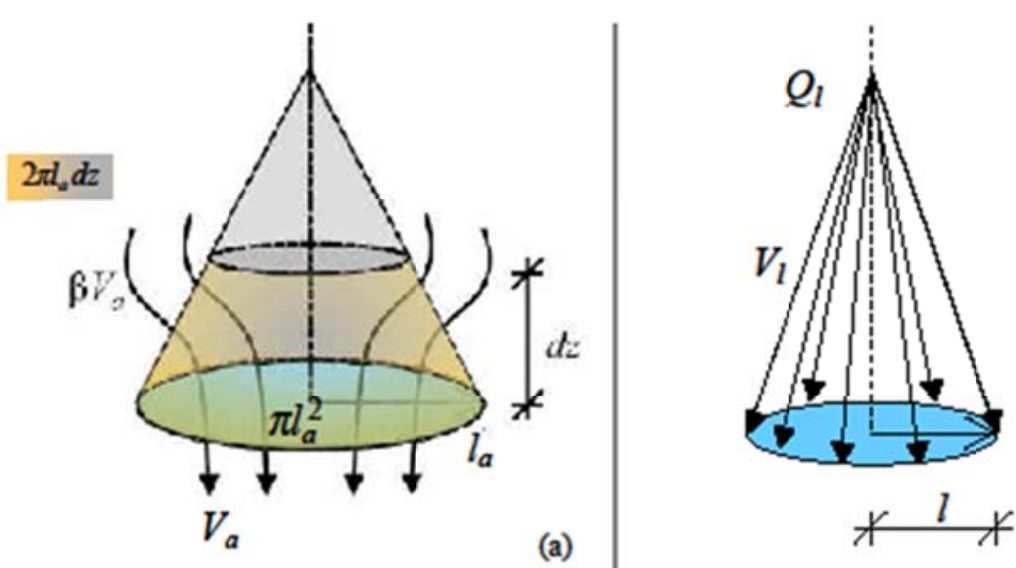

(b)

Figura 5.3 - (a) Jato de ar induzido pelo movimento do (b) jato de spray líquido Fonte: SILVA at. al., 2004

A fração de volume $(\alpha)$ pode ser definida facilmente a partir dia Figura 5.4 (b), como sendo a vazão de líquido distribuída na seção de área $\pi l^{2}$, com vellocidade $V_{l}$ ou seja, a relação entre o volume das gotas e o volume de spray.

$$
Q_{l}=\pi l^{2} V_{l} \alpha
$$

No ponto onde ocorre o rompimento do filme líquido, a velocidade de entrada das gotas é igual à velocidade do líquido e a largura do jato $\left(l_{a}\right)$ de ar é aproximadamente igual à largura do spray $\left(l_{0}\right)$ em $z=z_{0}$. Desta forma,

$$
V_{a}=V_{a_{0}} ; \quad V_{l}=V_{l_{0}} ; \quad l_{a}=l_{0}
$$

Considerando que a velocidade de entrada do ar $\left(V_{a}\right)$ tem um valor desconhecido, $V_{a_{0}}=b ; V_{l_{0}}$. Sem uma força externa que impulsione o fluxo de ar, a velocidade de entrada do ar $\left(V_{a_{0}}\right)$ deve ser sempre menor do que a velocidade média do líquido, ou seja, $b<1$. GHOSH E HUNT (1994), constataram que o valor de $V_{a_{0}}$ não tem efeito significante sobre os valores de $V_{a}$ e $l_{a}$ durante o fluxo do spray. Dessa forma, essas equações representam o comportamento dinâmico do spray.

GHOSH E HUNT (1994) concluíram que a pequenas distâncias do início do jato, $V_{a}$ se reduz mais lentamente do que um jato regular na relação $z^{-0,5}$ e que, a longas distâncias, $V_{a}$ decai como um jato regular, na relação $z^{-1}$. O ponto de transição do regime $z^{-0,5}$ para $z^{-1}$ 
acontece na distância de frenagem $(X s)$, distância ao longo da qual existe diferença significativa entre as velocidades da gota e do ar, conforme indicado na figura 5.3.

Os autores observaram, também, que o modelo unidimensional não é afetado pelas condições de entrada, quando $z \gg 5 z_{0}$. Desta forma, $b$ passa ser um valor arbitrário, desde que $b<1$, pois esta é a condição de contorno para que o spray seja essencialmente axial. Apesar de o valor de $b$ não influenciar significativamente quando $z \gg 5 z_{0}$, dependendo se $b$ for maior ou menor do que $b_{\text {crit }}$, a velocidade de entrada do ar decresce ou cresce, até um valor máximo. Essencialmente dois efeitos estão relacionados a estes comportamentos:

1) A velocidade do ar cresce como resultado da força de arrasto das gotas agindo sobre ele;

2) Decresce devido à rápida diminuição da força de arrasto média, resultante da ampliação do spray.

O valor de $b_{\text {crit }}$ é definido como:

$$
\begin{array}{cc}
b_{c r i t}=\frac{3 C_{D} Q_{l}}{16 l_{0} \beta \pi a V_{l_{0}}} & \text { Para spray estreito } \\
b_{\text {crit }}=\frac{3 C_{D} Q_{l}}{16 l_{0} \beta \pi a V_{l_{0}}} & \text { Para spray aberto }
\end{array}
$$

O modelo apresentado responde bem a interação do fluxo de ar junto as gotas aspergidas, entretanto, desconsideram a variação do diâmetro da gota, o que, por sua vez, desconsideram o processo de evaporação das gotas do spray. Foi verificado que, havendo ar em movimento haverá, também, uma condução das gotas sem que estas apresentem resistência ou interfiram no movimento do fluxo de ar (MURAKAMI et al., 1992). Assim, a velocidade relativa entre o fluxo de ar e as gotas será nula, e as trocas de calor e massa ocorrerão com $R e=0$. Como resultado da movimentação de ar ambiente, o spray sofrerá uma deformação, favorecendo a dispersão das gotas no ambiente e consequente evaporação. 


\subsection{Propriedades de Transferência de Calor e Massa}

A evaporação de partículas líquidas está comumente associada a um movimento relativo entre a gota e o ar ambiente. Estes perfis de velocidade têm um grande impacto nas trocas de massa, momento e energia entre o ar e as gotas, que podem ser modeladas em diferentes níveis de complexidade. SIRIGNANO (1999) apresenta seis modelos de vaporização de gotas, em ordem de complexidade crescente, são eles:

- Gota com temperatura constante (lei do quadrado do diâmetro);

- Líquido com difusividade térmica;

- Gota esférica com aquecimento transiente simétrico;

- Condutividade térmica efetiva;

- Aquecimento de gota com vórtices;

- Solução das equações de Navier-Stokes.

SIRIGNANO (1999) salienta que os três primeiros modelos desconsideram a circulação interna e podem ser aplicados diretamente em situações onde não haja movimento relativo entre a gota e o ar ou nos quais uma correção baseada no número de Reynolds possa ser aplicada para levar em conta a transferência convectiva de calor do ar ao líquido. Assim, o efeito da convecção deve ser tratado por uma correção adicionada.

FAETH (1977) afirma que uma solução transiente completa é por demais difícil de ser manuseada em comparação ao seu real valor numa análise de spray e, consequentemente, simplificações devem ser adotadas. Sem dúvida, o período de aquecimento da gota sempre retarda o início da efetiva evaporação, mas o efeito é mais importante sob alta pressão, pois, sob baixas pressões (pressões normais), a temperatura de bulbo úmido é relativamente baixa e o calor de vaporização é grande. Nestas condições o tempo de aquecimento da gota é pequeno em comparação ao tempo-de-vida e pode ser desprezado.

O modelo "líquido com difusividade térmica infinita" - é o que melhor representa a base teórica para a evaporação da gota até o estágio final de vaporização (FAETH, 1983). Este modelo de vaporização produz resultados de excelente correlação com os dados experimentais, mesmo com as simplificações admitidas em sua dedução.

Uma questão importante, no tocante ao estágio final de vaporização, refere-se ao limite de tamanho das partículas entre os comportamentos macroscópico e molecular. Segundo OLANDER (1994), o tamanho mínimo da partícula a ser considerado pode ser 
obtido a partir do conceito de livre caminho médio das moléculas do gás, obtido através da seguinte equação:

$$
\lambda=\frac{\mu}{I} \sqrt{\frac{\pi}{8 \rho p}}
$$

onde $\mu$ e $\rho$ são respectivamente a viscosidade absoluta e a densidade do gás, $I$ é o livre caminho médio das moléculas do $\operatorname{ar}\left(15-25^{\circ} \mathrm{C}\right), I$ é uma constante igual a 0,499 e $p$ é a pressão total do gás.

OLANDER (1994) sugere o número de Knudsen $(K n)$ como parâmetro para determinar se o escoamento se comporta como movimento contínuo ou molecular,

$$
K n=\frac{\lambda}{D} ;\left\{\begin{array}{c}
K n>10: \text { Movimento molecular } \\
10<K n<0,1: \text { Movimento Transacional } \\
\text { Kn }<0,1: \text { Movimento macroscópio contínuo }
\end{array}\right\}
$$

onde, $D$ é o diâmetro da gota.

A utilização deste parâmetro determinará quando as gotas serão consideradas totalmente evaporadas. Admitindo-se temperatura e pressão dentro das faixas presumidas, $\lambda$ assume valor de $0,0667 \mu \mathrm{m}$, o que implica na necessidade de partículas maiores ou iguais a aproximadamente $0,07 \mu \mathrm{m}\left(7 \times 10^{-8} \mathrm{~m}\right)$ para o fluido ser admitido como contínuo.

Por sua vez, FAETH (1977), também através do número de Knudsen, conclui que gotas menores do que $1 \mathrm{~mm}$ não mais podem ser tratadas por aproximações contínuas. Assim, considera-se a gota evaporada quando o diâmetro da mesma atingir esta ordem de grandeza.

Em função das considerações levantadas até o momento, é possível utilizar algumas hipóteses para simplificação do modelo de evaporação de gotas que preservam a essência física e concordam razoavelmente bem com resultados experimentais (TURNS, 1996). As simplificações utilizadas neste trabalho, e descritas a seguir, são fundamentadas nos estudos de FAETH (1977) e FAETH (1983) e são típicas da maioria dos modelos de evaporação de gotas, incluindo o modelo elaborado por SILVA et. al. (2004), que foi adotado para esse trabalho. São elas: 
- O spray é considerado como diluído em todos os pontos do escoamento, desconsiderando os efeitos de coalescência, colisão e o efeito de gotas adjacentes no transporte de calor e massa.

- Durante a vaporização, a superfície do líquido é assumida em equilíbrio termodinâmico com o vapor da mistura gasosa, desconsiderando a tensão superficial da gota.

- A pressão total é considerada constante e igual à pressão média ambiente.

- As propriedades do meio gasoso são admitidas constantes para cada instante de tempo.

Seguindo-se as formulações estabelecidas por FAETH (1983) e seguidas por SILVA et. al. (2004), e considerando-se a mistura gasosa composta apenas de ar seco e vapor de água, é possível analisar a transferência de calor e massa entre uma gota e o ar que a envolve. As seguintes três equações são utilizadas para estabelecer as trocas de calor e massa para condições de simetria esférica da gota.

1) Conservação de massa total:

$$
\frac{d}{d r}=\left(\rho_{g} v_{r} r^{2}\right)
$$

2) Conservação de cada espécie (água e ar ambiente):

$$
\frac{d}{d r}\left[r^{2}\left(\rho_{g} v_{r} Y_{i}-\rho_{g} D_{A B} \frac{d Y_{i}}{d r}\right)\right]=0
$$

3) Conservação de energia:

$$
\frac{d}{d r}\left[r^{2}\left(\rho_{g} v_{r} C_{p_{g}}\left(T-T_{\infty}\right)-k \frac{d T}{d r}\right)\right]=0
$$

Considerando que apenas a água tem transferência de massa, o calor específico da mistura gasosa $\left(c_{p_{g}}\right)$ é definido pela expressão: 


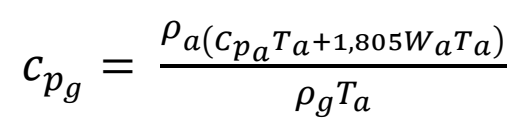

onde a densidade da mistura gasosa $\left(\rho_{g}\right)$, representando a soma das densidades do ar e do vapor nele contido, é calculada pela expressão:

$$
\rho_{g}=\rho_{a}\left(1+W_{a}\right)
$$

e a densidade do ar $\left(\rho_{a}\right)$ é definida por:

$$
\rho_{a}=\frac{p-\frac{p W_{a}}{W_{a}+0,62198}}{R_{a}\left(T_{a}+273,15\right)}
$$

sendo $R_{a}$ a constante do ar seco igual a $287,055 \mathrm{~J} / \mathrm{Kg} . \mathrm{K}$.

\subsubsection{Conservação de massa total}

Na consideração água e ar ambiente. Sendo o ar, no entanto, insolúvel na água, devemos nos ater somente na conservação da água. Integrando a equação 5.12, temos:

$$
\rho_{g} v_{r} r^{2}=c t e=\frac{\dot{m}}{4 \pi}
$$

onde $\dot{m}$ é a taxa de transferência de massa da gota para o ar e $v_{r}$ é a velocidade de retração (radial) da superfície da gota.

As trocas de calor e massa entre a gota aspergida e o ar circundante. O conteúdo de umidade e a temperatura na superfície do líquido se relacionam através da pressão de vapor, assim:

$$
W_{s}=0,62198 \frac{P_{W s}}{p-p_{w s}}
$$

onde $p$ é a pressão total e $p_{w s}$ é a pressão de saturação na temperatura da gota, definida como:

$$
p_{w s}=1000^{\left(A T_{l}^{2}+B T_{l}+C+D T_{l}^{-1}\right)}
$$

as constantes da equação são determinadas na tabela5.1, seguinte: 
Tabela 5.1 - Constantes para cálculo da pressão de saturação de vapor da água Fonte: ASHRAE (1996)

\subsubsection{Conservação de cada espécie (água e ar ambiente)}

Integrando-se a equação 5.13 (conservação da espécie) e aplicando-se as condições de contorno, obtém-se, segundo FAETH (1977) e FAETH (1983), o fluxo de massa líquida evaporada, para uma gota isolada, obtemos:

$$
\dot{\mathrm{m}}=4 \pi a^{2} \rho_{g} h_{m} B_{y}
$$

onde $B_{y}$ é número de transferência de massa de Spalding.

O coeficiente de transferência convectiva de massa $\left(h_{m}\right)$ pode ser obtido através do

\begin{tabular}{lll}
\hline & \multicolumn{3}{c}{ TEMPERATURA (K) } \\
\hline & $273,15 \leq \mathrm{T}<322,15$ & $322,15 \leq \mathrm{T}<373,15$ \\
\hline A & $0,1255001965 \times 10^{-7}$ & $0,1246732157 \times 10^{-7}$ \\
B & $-0,1923595289 \times 10^{-1}$ & $-0,1915465806 \times 10^{-1}$ \\
C & $0,2705101899 \times 10^{2}$ & $0,2702388315 \times 10^{2}$ \\
D & $-0,6344011577 \times 10^{4}$ & $-0,6340941639 \times 10^{4}$ \\
\hline
\end{tabular}

gradiente de concentração definido pelo adimensional de Sherwood $(S h)$.

$$
S h=\frac{2 a h_{m}}{D_{A B}}=2 \frac{\ln \left(1+B_{y}\right)}{B_{y}}, R_{e}=0
$$

Se $B_{y}$ tende a zero, o número de Sherwood $(S h)$ tende a 2, que é o valor adotado para esfera baixas taxas de transferência de massa (FAETH 1977). Sendo assim, o coeficiente convectivo de massa fica assim:

$$
h_{m R e}=\frac{D_{A B}}{a}, R_{e}=0
$$

\subsubsection{Conservação de energia}

Integrando a Equação 5.14 e aplicando as condições de contorno, obtém a expressão para o coeficiente de transferência de calor $(h)$, descrito em relação ao gradiente de temperatura definido pelo número de $\operatorname{Nusselt~}(\mathrm{Nu})$. 


$$
N u=\frac{2 a h}{k}=\frac{\dot{\mathrm{m}}_{C_{P a}}}{2 \pi a k}\left[\exp \left(\frac{\dot{\mathrm{m}}_{C_{P a}}}{4 \pi a k}\right)-1\right]^{-1}, R_{e}=0
$$

No mesmo caso, se m tende a zero, o número de Nusselt tende a 2. Sendo assim, para $R_{e}=0$, o coeficiente de convecção pode ser escrito como:

$$
h_{R e}=\frac{k}{a}, R_{e}=0
$$

O fluxo de calor local $(\dot{q})$ tem como variáveis o coeficiente de convecção e a diferença de temperatura e é descrito como:

$$
\dot{q}=h\left(T_{a}-T_{l}\right)
$$

No entanto, o desenvolvimento da teoria da evaporação de sprays requer considerar o efeito da movimentação das gotas nas trocas de calor e massa, tanto quanto nas expressões de arrasto. Esta condição deve ser considerada nas equações que regem a conservação de movimento, que foram descritas nessa seção com as equações que regem as trocas de calor e massa das gotas em movimento (SILVA et. al., 2004).

Efetuando as correções propostas por FAETH (1983) e TURNS (1996), e substituindo os valores nas equações de conservação de massa e energia, se consegue chegar ao comportamento da gota desde sua formação e durante a fase de fluido contínuo.

Reorganizando as equações e considerando a densidade do liquido $\left(\rho_{l}\right)$ constante, a variação do diâmetro da gota $(D)$ ao longo do tempo $t$ pode ser obtida a partir da seguinte constatação:

$$
\dot{\mathrm{m}}=\frac{d m_{l}}{d t}=\frac{d}{d t}\left(\rho_{l} \frac{\pi}{6} D^{3}\right)
$$

Considerando $\rho_{l}$ constante, temos:

$$
\frac{d D}{d t}=\frac{2 \dot{\mathrm{m}}}{\pi \rho_{l} D^{2}}
$$

que por sua vez ao ser derivada em $z$ e reescrita em função do raio (a), torna-se, 


$$
\frac{d a}{d z}=-\frac{\dot{\mathrm{m}}}{4 \pi a^{2} \rho_{l} V_{l}}
$$

Essas equações determinam as variáveis das trocas de calor e massa da gota isolada e seu comportamento durante do fluxo.

\subsection{Estudo da Evaporação do Spray}

Seguindo o mesmo modelo de cálculo de conservação de massa e de energia adotado para as partículas discretas, para o volume de controle. Na escala do spray a fração de volume $(\alpha)$ é utilizada como base de cálculo das variáveis, apresentadas na figura 5.4.

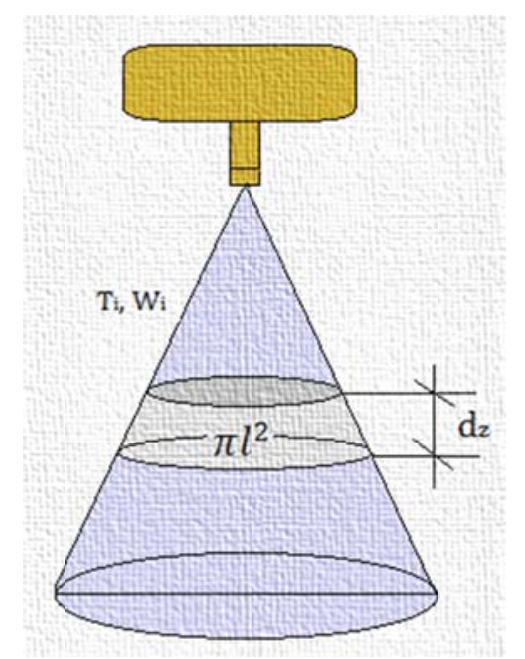

Figura 5.4 - Estabelecendo o volume de controle para o spray

$$
\frac{d \forall}{d z}=\pi l^{2}
$$

O volume de controle é definido pelo raio do $\operatorname{spray}(l)$, onde realmente acontecem as trocas de calor e massa, e não pelo raio do jato de ar $\left(l_{a}\right)$. Quando o spray for amplo (c> $0,194)$ ambos assumem o mesmo valor $\left(l=l_{a}\right)$. Considerando todas as gotas de igual tamanho, a partir do conceito de fração de volume $(\alpha)$ é possível determinar o número de gotas $(N)$ dentro do volume de controle, segundo a seguinte relação:

$$
N=\frac{\pi l^{2} d z}{\frac{4}{3} \pi a^{3}}
$$


Substituindo a equação 5.6 no valor de $\alpha$, o cálculo do número de gotas $(N)$ :

$$
N=\frac{3}{4} \frac{Q_{l}}{\pi a^{3} V_{l}} d z
$$

Considerando a evaporação das gotas, a vazão de líquido, $Q_{l}$ será variável em função de $z$. A variação da vazão de líquido $\left(Q_{l}\right)$, então, equivale ao somatório do fluxo de massa de cada uma das gotas do volume de controle:

$$
\frac{d Q_{l}}{d z}=\frac{3}{4} \frac{\dot{\mathrm{m}} Q_{l}}{\pi a^{3} \rho_{l} V_{l}}
$$

\subsubsection{Conservação de massa de vapor no volume de controle}

Já foram estudadas as variáveis referentes ao líquido (gota), através dos modelos de cálculos do comportamento dinâmico das partículas discretas. No que se refere ao ar só são conhecidas apenas a variação da velocidade $\left(V_{a}\right)$ e a variação do raio do jato dle ar $\left(l_{a}\right)$, obtidas no estudo do comportamento dinâmico. A variação do conteúdo de vapor no ar do spray, podemos obter pelo balanço de massa de vapor no volume de controle, representado na figura 5.5, abaixo:

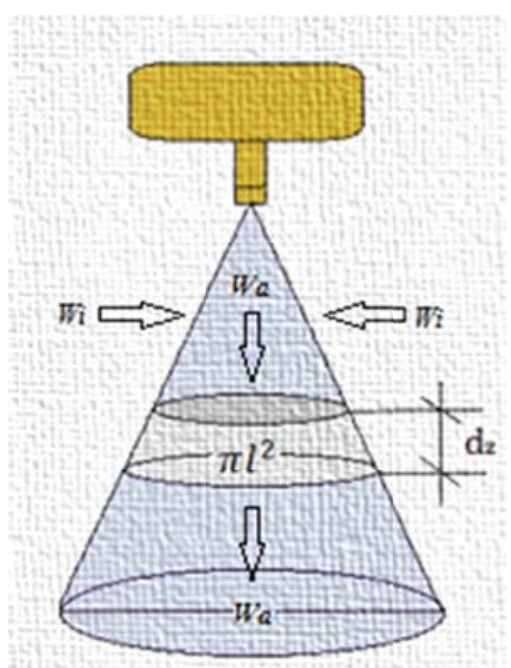

Figura 5.5 - Conservação de massa de vapor no volume de controle

A equação que representa o balanço de vapor no volume de controle é a seguinte:

$$
\frac{d}{d z}\left[\rho_{a} V_{a} \pi l^{2} W_{a}(1-\alpha)\right]-\pi \rho_{i} W_{i} \frac{d}{d z}\left[l^{2} V_{a}\right]-\frac{3}{4} \frac{\dot{\mathrm{m}} Q_{l}}{\pi a^{3} V_{l}}=0
$$


onde a primeira parcela representa a variação do conteúdo de vapor no volume de controle; a segunda parcela representa a quantidade de vapor que entrou no volume de controle com o ar induzido do ambiente e a última parcela representa o fluxo de massa das gotas que é cedido ao ar do volume de controle, durante a evaporação.

Cabe lembrar que a segunda parcela que representa o ingresso de ar induzido que foi calculada com base no raio do spray que, no caso do spray estreito, é função direta do coeficiente de indução $(\beta)$. Entretanto, como estamos trabalhando com spray amplo, esta variação independe de $\beta$

\subsubsection{Conservação de energia no volume de controle}

As energias envolvidas constam apenas de energia térmica, medida pela entalpia específica e pelos calores específicos envolvidos $\left(C_{p_{l}}\right.$ e $\left.C_{p_{a}}\right)$. A entalpia da mistura é determinada pelas entalpias do vapor de água $(v)$ e do ar seco, consideradas as respectivas massas. O princípio é que o vapor de água está em equilíbrio termodinâmico e em mistura homogênea com o ar.

A variação da temperatura do ar do spray $\left(T_{a}\right)$, no interior do volume de controle é determinada pelo balanço de energia.

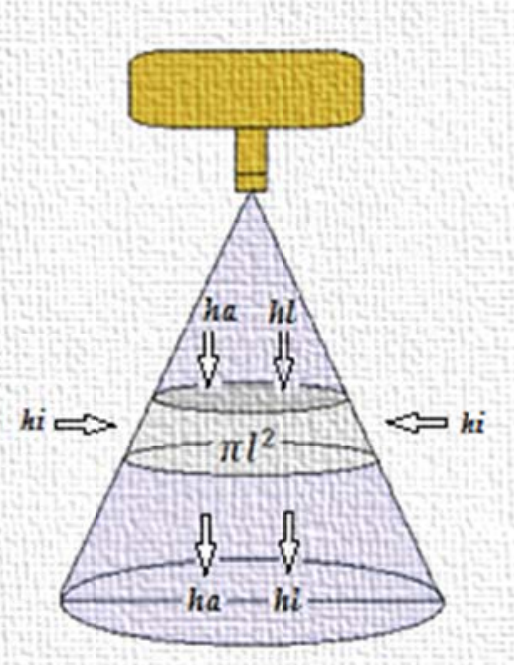

Figura 5.6 - Conservação de energia no volume de controle

$$
\frac{d}{d z}\left[\rho_{a} V_{a} \pi l^{2} h_{a}(1-\alpha)\right]-\pi \rho_{i} h_{i} \frac{d}{d z}\left[l^{2} V_{a}\right]+\rho_{l} C_{p_{l}} \frac{d}{d z}\left(T_{l} Q_{l}\right)=0
$$


(eq.5.35)

onde a primeira parcela representa a variação da entalpia do ar no volume de controle $\left(h_{a}\right)$, considerada a fração de vazios (1- $\alpha)$; a segunda parcela representa a entalpia do ar induzido do ambiente $\left(h_{i}\right)$ que penetra no volume de controle e a última parcela representa a variação de entalpia do líquido $\left(h_{l}\right)$ no volume de controle, cujo o cálculo foi estabelecido no modelo de partículas discretas.

As entalpias do líquido e do ar úmido, respectivamente para o ar do spray e o ar induzido no ambiente, tendo como referência o ar e a água a uma temperatura de $0^{\circ} \mathrm{C}$, são assim definidas:

Líquido:

$$
h_{l}=C_{p_{l}} T_{l}
$$

Ar úmido:

$$
h_{a}=C_{p_{a}} T_{a}+W_{a}\left(2501+1,805 T_{a}\right)
$$

Ar induzido:

$$
\mathrm{h}_{\mathrm{i}}=\mathrm{C}_{\mathrm{p}_{\mathrm{a}}} \mathrm{T}_{\mathrm{i}}+\mathrm{W}_{\mathrm{i}}\left(2501+1,805 \mathrm{~T}_{\mathrm{i}}\right)
$$

Com as equações de balanço de massa de vapor e energia, completa-se o sistema composto de oito (8) equações diferenciais ordinárias não-homogêneas, em função da distância $z$, para obtenção das variáveis $l_{a}, V_{a}, V_{l}, a, T_{l}, Q_{l}, W_{a}$ e $T_{a}$ que, juntamente com $l$, descrevem o comportamento do spray ao longo do escoamento, a partir da formação do mesmo $\left(z_{0}\right)$ até a evaporação completa das gotas.

\subsection{Características da Edificação}

A proposta da instalação de um sistema de resfriamento evaporativo em uma edificação é a de promover, no ambiente interno, alterações nas condições de temperatura e umidade a favor do conforto térmico, tanto humano quanto para melhoria no desempenho das atividades desenvolvidas. No que se refere ao spray, o estudo efetuado visa permitir uma integração entre a edificação e o spray de tal forma que a evaporação completa das gotas 
micro aspergida seja garantida. As propriedades físicas da massa de ar, resultante do contato com as gotas, constituem o termo de conexão entre o spray e o edifício.

SILVA et. al. (2004) salienta que entre a solução do spray e a avaliação do comportamento do edifício existe um processo de mistura de massas de ar em diferentes condições de temperatura e umidade, que estão exemplificados na figura 5.7. As massas de ar interno, de ar externo e de ar tratado pelos aspersores interagem ao longo do tempo com as fontes de calor sensível e latente do edifício. Com exceção das condições do ar externo todas as demais variáveis são interdependentes.

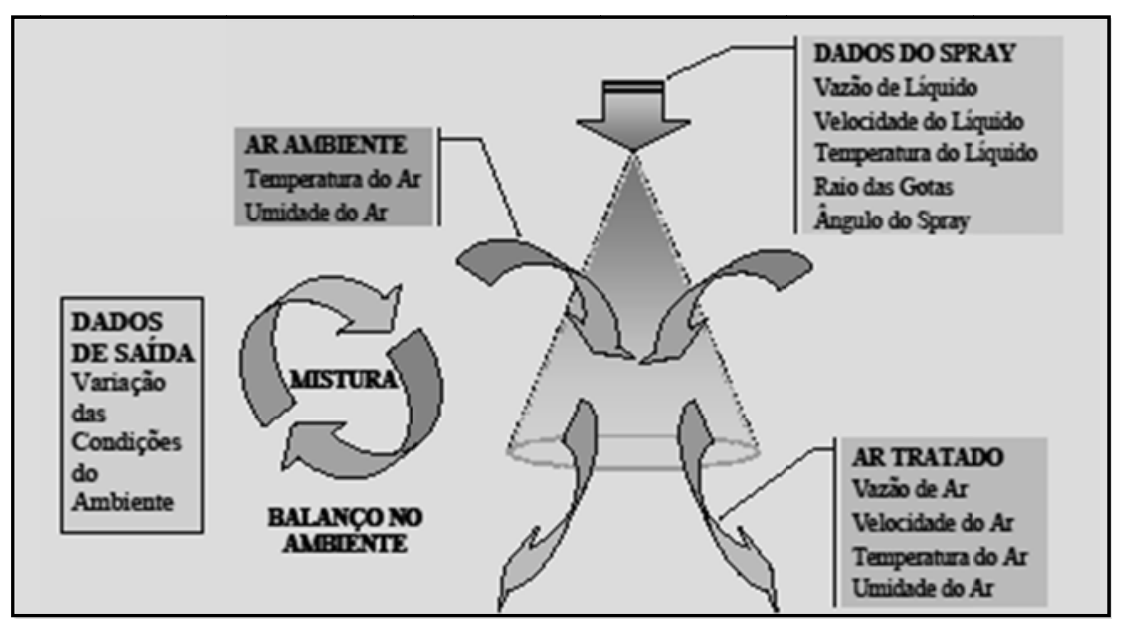

Figura 5.7 - Esquema de integração entre o modelo do spray e o ambiente Fonte: SILVA et. al., 2004

A avaliação do que ocorre com o ar interno, ou seja, as alterações de temperatura e umidade que ocorrem durante o processo de resfriamento evaporativo, passa por algumas fases que precisam ser analisadas em separado. São elas:

1) No instante inicial $(t=0)$ temos a condição do ar interior na edificação.

2) Parte do ar ambiente é tratado pelos aspersores, ou seja, água é adicionada ao ambiente.

3) O spray trata parte do ar ambiente e as partes não tratadas se misturam com as partes tratadas, obtendo-se um ar de mistura ou ar climatizado, propriamente.

4) A edificação, por sua vez não é um ambiente hermético, pois permite a ocorrência de uma renovação de ar em determinado $\Delta t$, ou seja, temos a ocorrência de um insuflamento de ar externo ao ambiente climatizado. 
5) Uma nova mistura ocorre gerando uma nova condição térmica que, por sua vez recebe a carga térmica do ambiente e altera suas propriedades físicas no intervalo de tempo $\Delta t$.

As propriedades do ar, agora integradas ao ambiente da edificação e a climatização promovida pelos sprays, tem as suas fases equacionadas como segue:

A pressão parcial do ar interno pode ser calculada pela soma das pressões parciais de cada substância presente na mistura (ar Seco e vapor de água):

$$
P=P_{a}+P_{v}
$$

Tratando o vapor de água e o ar seco como gases ideais, e constatando que a pressão total é a soma das pressões do vapor e do ar seco, as densidades do vapor de água, do ar seco e da mistura na interface ar-água, podem ser calculadas pela equação dos gases perfeitos:

$$
\rho_{a}=\frac{P_{a}}{R_{a} T}
$$

A vazão mássica do ar seco é dada pela diferença entre a vazão mássica do ar úmido e a vazão mássica do vapor de água, ou pela multiplicação da vazão em volume do ar pela densidade do ar seco.

$$
\begin{aligned}
& \dot{\mathrm{m}}_{a}=\dot{\mathrm{m}} * \dot{\mathrm{m}}_{v} \\
& \dot{\mathrm{m}}_{a}=Q * \rho_{a}
\end{aligned}
$$

$\mathrm{Na}$ gama de temperaturas em que normalmente operam os processos de climatização (de $-10^{\circ} \mathrm{C}$ a $50^{\circ} \mathrm{C}$ ), a entalpia e a variação da entalpia dependem apenas do valor da temperatura do ar úmido ou da sua variação e o calor específico é assumido constante (ASHRAE, Psychrometrics, 2009),

$$
h_{a} \cong 1,006 * T
$$

O valor da pressão parcial do vapor de água é obtido através do produto entre a humidade relativa e a pressão de saturação do vapor de água (ASHRAE, Psychrometrics, 2009). 


$$
\emptyset=\frac{\boldsymbol{p}_{\boldsymbol{v}}}{\boldsymbol{P}_{v_{-} s a t}}
$$

sendo a densidade do vapor de água:

$$
\rho_{v}=\frac{P_{v}}{R_{v} \times T}
$$

A vazão mássica do vapor de água é o produto da vazão mássica do ar seco pela umidade absoluta, ou então pela multiplicação da vazão em volume do ar úmido pela densidade do vapor de água:

$$
\begin{aligned}
& \dot{\mathrm{m}}_{v}=\dot{\mathrm{m}}-\dot{\mathrm{m}}_{a} \\
& \dot{\mathrm{m}}_{v}=\dot{\mathrm{m}}_{a} * W \\
& \dot{\mathrm{m}}_{v}=Q * \rho_{v}
\end{aligned}
$$

Considerando a entalpia do vapor de água a $0^{\circ} \mathrm{C}$, aproximadamente igual a $2501 \mathrm{~kJ} /$ $\mathrm{kg}$ e o valor do seu calor específico à mesma temperatura de $1,86 \mathrm{~kJ} / \mathrm{kg} .{ }^{\circ} \mathrm{C}$, a entalpia do vapor de água pode ser, aproximadamente, determinada pela seguinte equação (ASHRAE, Psychrometrics, 2009):

$$
h_{v}=2501 * 1,805 T
$$

O valor da densidade do ar úmido é dado pela soma da densidade do ar seco e da densidade do vapor de água, ou seja:

$$
\rho=\rho_{v}+\rho_{a}
$$

A vazão mássica do ar úmido é obtida pelo produto da vazão mássica do ar úmido pela densidade do vapor de água ou pela soma entre a vazão mássica do ar seco e a vazão mássica do vapor de água:

$$
\dot{\mathrm{m}}=\dot{\mathrm{m}}_{v}+\dot{\mathrm{m}}_{a}
$$




$$
\dot{\mathrm{m}}=Q * \rho
$$

A quantidade de vapor de água contida no ar pode ser traduzida pela relação direta entre a massa de vapor de água e a massa de ar seco presentes numa dada quantidade de ar úmido, essa relação traduz a fração mássica de vapor de água contida no ar seco e que é a umidade absoluta definida por (ASHRAE, Psychrometrics, 2009):

$$
W=0,62198 \frac{P_{v}}{P-P_{v}}
$$

A entalpia da mistura de gases perfeitos é igual à soma das entalpias parciais de cada substância, portanto, a entalpia do ar húmido pode ser calculada a partir de (ASHRAE, Psychrometrics, 2009):

$$
h=h_{a}+W * h_{v}
$$

\subsubsection{Análise do desempenho térmico de edificações, num intervalo de tempo}

Condição do ar interior, arbitrada no instante inicial $(t=0)$ é a massa de ar interior após receber calor sensível $\left(q_{s}\right)$ e latente $\left(q_{L}\right)$ do ar ambiente.

Ar ambiente $(a m b)$ é condição inicial do ar interior no instante inicial $(\boldsymbol{t}=\mathbf{0}) \mathrm{e}$ obtidas as condições do ar interior no tempo $t+\Delta t$.

Mistura (mist) ganha calor do ambiente e altera suas propriedades físicas no tempo $\Delta t$. Sendo assim, temos:

$$
\begin{aligned}
& h_{a m b}=h_{m i s t}+\frac{q_{s}}{m_{m i s t}} \\
& W_{a m b}=W_{m i s t}+\frac{q_{l}}{m_{m i s t}+h_{l v}} \\
& T_{a m b}=\frac{h_{m i s t}-2501 W_{m i s t}}{C_{p_{a}}+1,805 W_{a m b}}
\end{aligned}
$$


Massa de ar tratado pelos aspersores $\left(m_{\text {trat }}\right)$, cujas condições $\left(h_{\text {trat }}, W_{\text {trat }}\right)$ são obtidas da resolução do spray, sendo a quantidade total de ar tratado dependente do número de aspersores instalados e da sua distribuição na área.

Massa de ar interior resultante da mistura do ar tratado pelos aspersores $\left(m_{\text {trat }}\right)$ com a parcela de ar não tratado $\left(m_{a m b}-m_{\text {trat }}\right)$, resulta no ar climatizado:

$$
\begin{gathered}
\left(m_{a m b}-m_{\text {trat }}\right) h_{a m b}+m_{\text {trat }} h_{\text {trat }}=m_{a m b} h_{c l i m} \\
\left(m_{a m b}-m_{\text {trat }}\right) W_{a m b}+m_{\text {trat }} W_{t r a t}=m_{a m b} W_{c l i m} \\
T_{c l i m}=\frac{h_{c l i m}-2501 W_{c l i m}}{c_{p_{a}}+1,805 W_{c l i m}}
\end{gathered}
$$

Na condição de ar climatizado (clim), a parcela da massa de ar interna deixa o ambiente $\left(m_{\text {clim }}-m\right)$ no intervalo de tempo $\Delta t$.

A massa de ar exterior $(m)$, é a que entra na edificação no intervalo de tempo $\Delta t$, cujas condições de entalpia e umidade $(h, W)$ já são conhecidas inicialmente.

Massa de ar interior $\left(m_{\text {clim }}\right)$, cujas condições $\left(h_{\text {clim }}, W_{\text {clim }}\right)$ são as mesmas calculadas. A massa correspondente a quantidade de ar contida no ambiente.

Massa de ar interior $\left(m_{\text {mist }}\right)$ resultante da mistura de ar nas condições externas e após climatização $\left(m_{\text {clim }}+m\right)$, segundo as equações:

$$
\begin{gathered}
m . h+m_{c l i m} h_{c l i m}-m_{c l i m} W_{c l i m}=m_{c l i m} h_{m i s t} \\
m, W+m_{c l i m} W_{c l i m}-m_{c l i m} h_{c l i m}=m_{c l i m} W_{m i s t} \\
T_{\text {mist }}=\frac{h_{\text {mist }}-2501 W_{\text {mist }}}{C_{p_{a}+1,805 W_{\text {mist }}}}
\end{gathered}
$$

O sistema composto pelas equações diferenciais apresentadas e as demais equações algébricas que compõem o modelo de cálculo matemático do spray podem ser resolvidas no 
ambiente computacional do Fortran Power Station 4.0. Através de uma completa biblioteca de funções e rotinas matemáticas que, amplamente testadas, permite a solução de problemas matemáticos bastante complexos com alto grau de precisão e confiabilidade.

Essa sequência de equações permite simular o desempenho térmico de um sistema de resfriamento evaporativo em um ambiente de instalação. Entretanto alguns fatores práticos não considerados não garantem que toda água micro aspergida se evapore. A utilização de micro aspersores diretamente no ambiente gera umidades imprevisíveis, devido a uma ausência de alguns parâmetros de controle do processo alheios a nossa interferência, como a velocidade com que o ar ambiente se renove, ou ainda, pontos localizados onde a circulação de ar é deficiente, atividades que geram umidades localizadas ou cargas térmicas. Estas características interferem significativamente no potencial de resfriamento possível.

Os cálculos aqui apresentados permitem um dimensionamento correto da instalação, mas não garantem que a evaporação total da água micro aspergida ocorra, podendo gerar pontos localizados de umidade excessiva ou de não alcance das condições térmicas desejadas para atingir a condição de conforto ambiental. 
A implementação do modelo de cálculo busca considerar todas as variáveis que interferem no tanto no desempenho de um sistema de resfriamento evaporativo de alta pressão quanto no resultado de conforto térmico que se pode alcançar em uma edificação. Estas variáveis podem ser classificadas em 4 grupos:

1) Variáveis ambientais

- Altitude

- Temperatura do Ar Exterior

- Umidade Relativa Externa

2) Variáveis de projeto

- Área

- Pé-direito

- Temperatura Inicial do Ar Interior

- Umidade Relativa Inicial Interna

- Taxa de Renovação de Ar

- Número de Aspersores

- Carga Térmica Sensível

- Carga Térmica Latente

3) Variáveis de controle

- Máxima Umidade Relativa Permitida

- Mínima Umidade Relativa Permitida

- Máxima Temperatura do Ar Permitida

- Mínima Temperatura do Ar Permitida

- Histerese de Umidade e de Temperatura

- Maior Tempo Desligado

- Menor Tempo Desligado

- Maior Tempo Ligado

- Menor Tempo Ligado 
4) Variáveis do spray

- Ângulo do Spray

- Vazão do Spray

- Raio das Gotas

- Velocidade de Entrada das Gotas

- Temperatura de Entrada das Gotas

Na prática, uma instalação de um sistema de resfriamento evaporativo, por aplicação direta do spray no ambiente, se faz partindo de uma análise da área a ser climatizada que, basicamente, envolve as variáveis de projeto, afim se se verificar a viabilidade técnica da instalação, ou seja, se as condições de conforto térmico podem ser alcançadas. Constatando a viabilidade de se alterar as condições de temperatura e umidade iniciais a favor do conforto térmico humano ou de padrões específicos que atendam as atividades produtivas desenvolvidas, se determina o número de aspersores mais adequados aquela área.

O Cálculo do Projeto de instalação é desenvolvido com base nas variáveis de projeto descritas, considerando o volume de ar da área a ser climatizada, sua umidade relativa e temperatura, verificando a quantidade de água que pode ser absorvida por este volume em questão mantendo a umidade relativa máxima dentro das condições de conforto térmico exigidos pelo ambiente. Como resultado do cálculo, se obtém o número de aspersores que serão instalados na área climatizada. Normalmente, quando não existe nenhuma interferência física na área em questão os aspersores são uniformemente dispostos em toda extensão da edificação. Uma instalação típica é apresentada na figura 6.1.

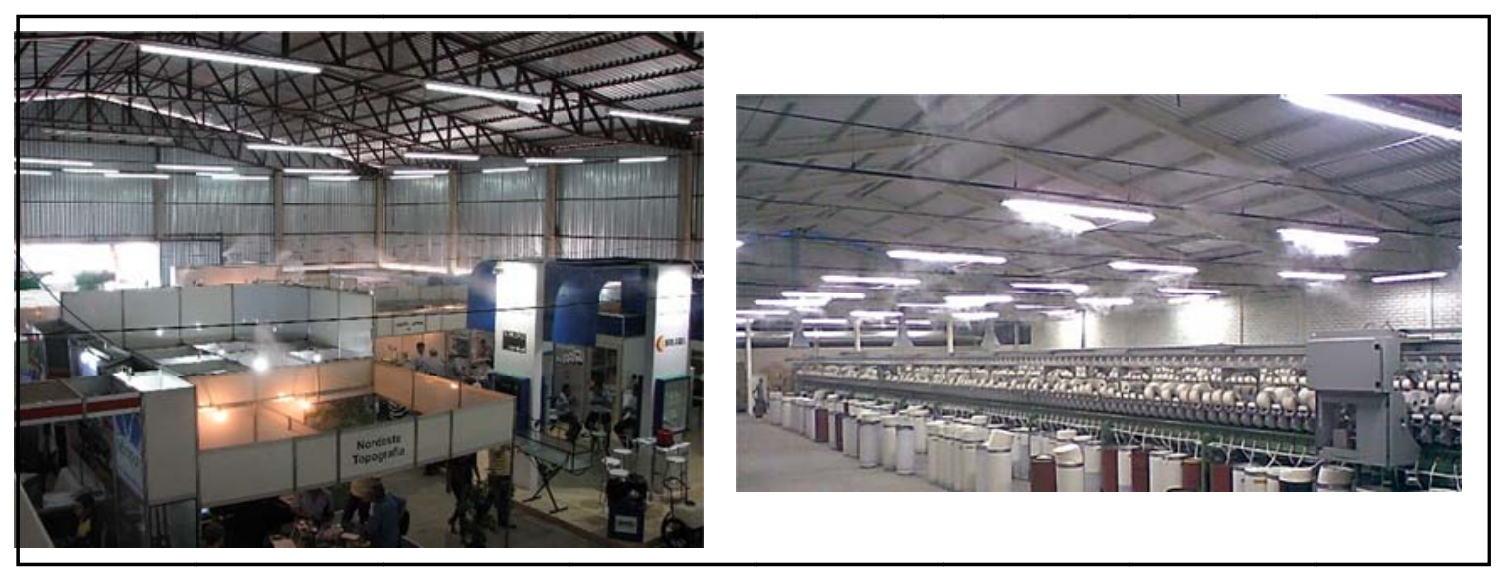

Figura 6.1 - Instalação de micro aspersores internos na área, com alta e baixa troca de ar Fonte: Instalações executadas pelo próprio autor em 2012 - Araraquara - SP 
Uma vez concluída a distribuição dos aspersores na área, o projeto de climatização foca, agora, no padrão de acionamento que melhor atende os requisitos operacionais da instalação. Hoje em dia, de um simples botão ON/OFF até sistemas sofisticados advindo do avanço da eletrônica, que permite a utilização de microprocessadores controlados por supervisórios sofisticados, com comunicação via radio e wireless, tornou o computador uma peça chave na operação destes sistemas.

Basicamente, a operação de um sistema necessita capturar as variáveis de projeto e processar as informações que vem de sensores de temperatura e umidade e corrigir a aplicação para alcançar a zona de conforto térmico. Dependendo das características área climatizada, comunicação de dados entre os sensores e a operação do sistema pode dispensar determinados níveis de sofisticação. A figura 6.2 apresenta os instrumentos mais comumente usados nas instalações.

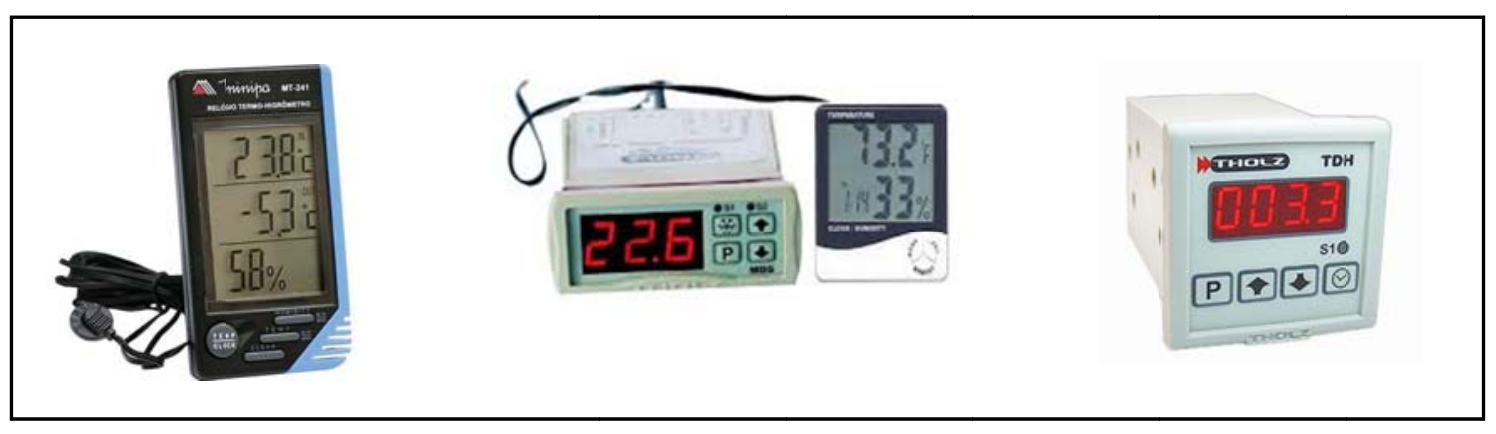

Figura 6.2. - Instrumentos de controle mais comuns utilizados nas instalações

Na condição operacional, a única ação controlada do sistema é o tempo de operação do equipamento de pressurização (bomba de pressão), ou seja, o tempo ligado e desligado do equipamento como forma de regular a quantidade de água micro aspergida no ambiente. Todas as informações capturadas pelos sensores são traduzidas no tempo ligado e tempo desligado do equipamento. A forma operacional mais comum utilizada nas instalações é uma leitura via termo higrômetro seguido de ajuste dos tempos de operação com um temporizador cíclico.

$\mathrm{Na}$ maioria dos casos a medição dos resultados de conforto térmico alcançados pelo sistema não está na precisão dos resultados, mas sim na sensação de conforto produzida e nas interferências que causam nas atividades desenvolvidas, daí a possibilidade de se utilizar recursos menos sofisticados a nível tecnológico. 
Os monitoramentos dos dados capturados pelos sensores vão revelar, ocasionalmente, alterações das condições ambientas. O consequente ajuste das operações (tempo ligado e tempo desligado), tem que ser feito em concordância com as alterações destas variáveis, uma vez que interferem diretamente na taxa de evaporação do spray. Afim de se evitar umidades imprevisíveis, um recurso que, também, se utiliza é acoplar os aspersores a ventiladores e, assim, acelerar a evaporação, conforme mostrado na figura 6.3 .

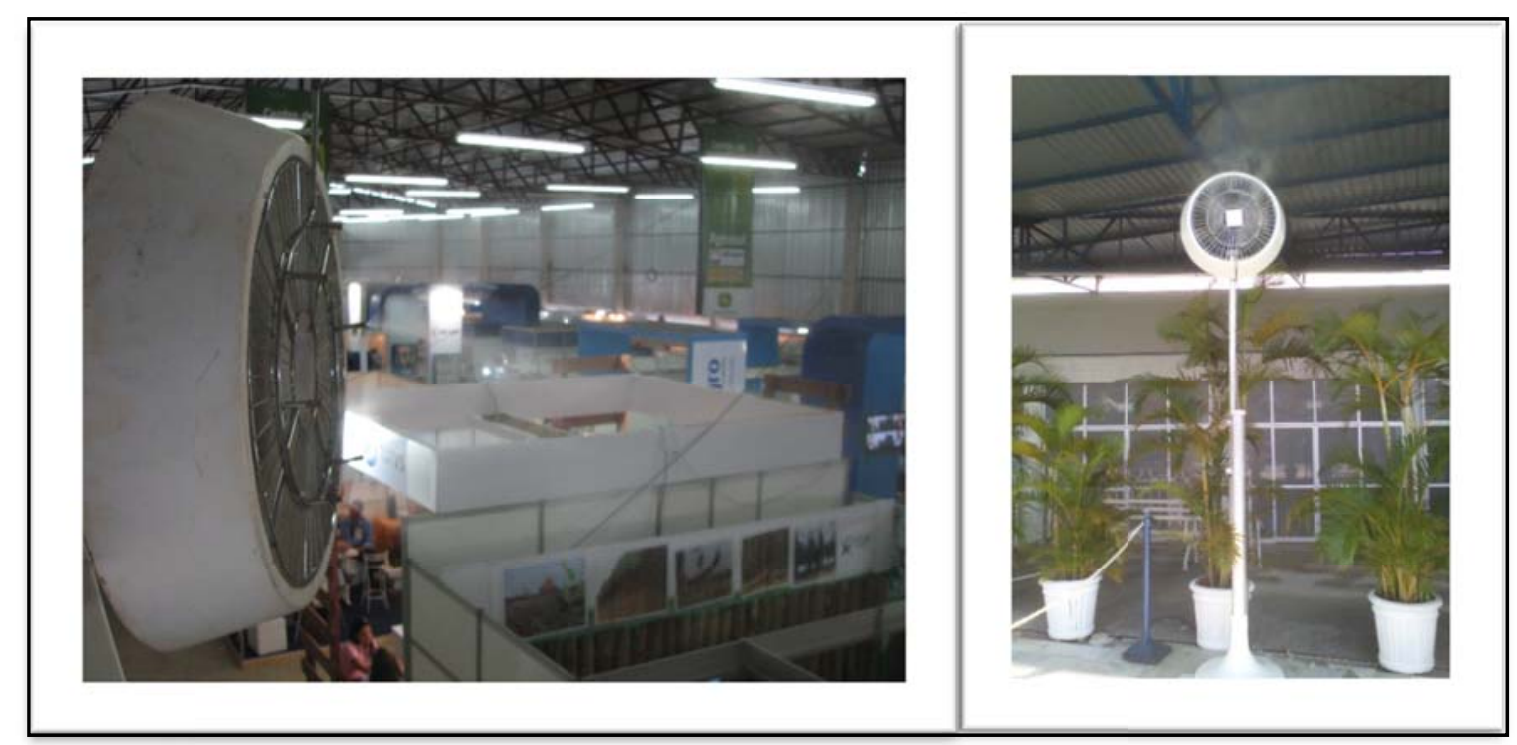

Figura 6.3 - Micro aspersores acoplados a ventiladores

Fonte: Instalação executada pelo autor em 2015 - Luiz Eduardo Magalhães - BA

Essas características fazem com que o principal fator que limita a aplicação do sistema ou, até mesmo, a causa dos problemas apresentados nas instalações, estão relacionados a taxa de evaporação que, por sua vez, sofre interferências das variáveis ambientais como temperatura e umidades externas e das variáveis de projeto, tais como a taxa de renovação de ar e, em alguns a casos, as variações da carga térmica sensível.

A água aspergida troca calor sempre com o ar não saturado e sua temperatura de equilíbrio termodinâmico com o ar define a temperatura termodinâmica de bulbo úmido. $\mathrm{O}$ fenômeno da evaporação é complexo onde o líquido se desintegra devido a energia cinética do próprio líquido ou por exposição a alta velocidade do ar (natural ou forçada). O comportamento dinâmico é caracterizado pela velocidade das gotas e a velocidade do ar, 
enquanto que o fenômeno de transporte entre as fases líquido e vapor é caracterizado pelas temperaturas do líquido e do ar, umidade relativa do ar e a vazão do líquido.

Por sua vez, a velocidade do spray faz com que haja uma transferência da quantidade de movimento das gotas para o ar circundante, induzindo este a uma velocidade que define a variação do raio do spray, as trocas de calor e massa entre as fases e a distância alcançada pelo jato.

Uma das maiores dificuldades das instalações dos sistemas de resfriamento evaporativo reside na existência de incertezas em qualquer resultado. Possibilitar um controle dos parâmetros, minimizando os erros de aplicação, antes que se crie no ambiente um desconforto de tal grau que inviabilize sua aplicação é um fundamento deste trabalho. A busca passa a ser pela garantia da aceitabilidade dos resultados do sistema projetado e seus limites de aplicabilidade. A esta dificuldade, soma-se a carência na literatura de dados úteis em evaporação de sprays que possam ser utilizados na validação da performance de modelos (BECK e WATKINS, 2003).

$\mathrm{Na}$ ausência de dados experimentais e de outras simulações para se estabelecer um modelo de evaporação de spray que apresente uma maior confiabilidade de resultados, SILVA et. al. (2004), executaram algumas avaliações paramétricas que possibilitaram uma análise qualitativa do modelo de desempenho dessa aplicação.

\subsection{Avaliações Quantitativas}

\subsubsection{Ar induzido}

SILVA et. al. (2204) fizeram um comparativo da velocidade das gotas em relação a velocidade do ar, apresentado na figura 6.4, onde se pode observar a indução do ar pela transferência da quantidade de movimento das gotas para o ar.: 


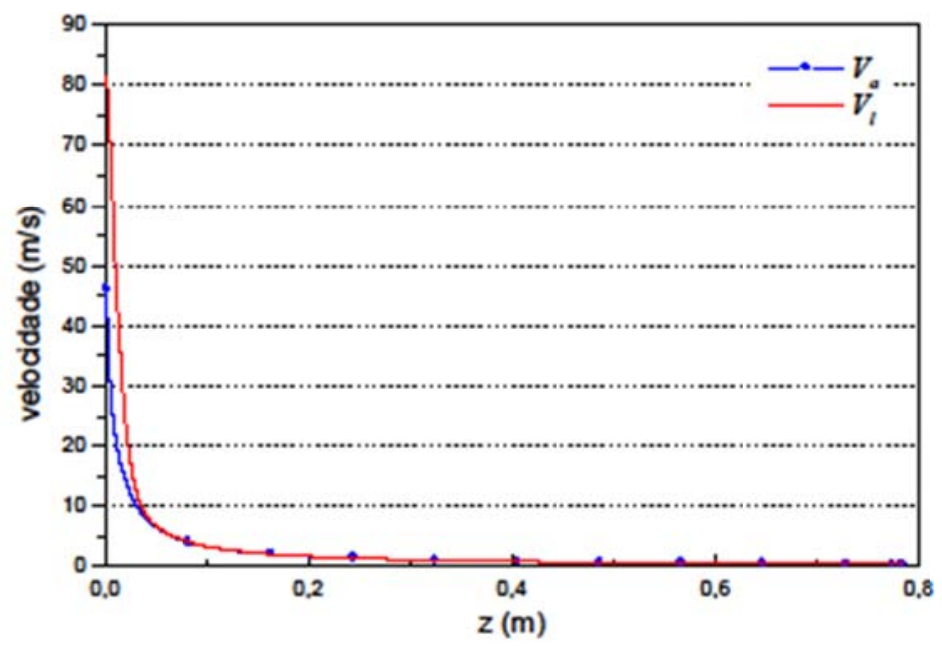

Figura 6.4 - Variação das velocidades do líquido $\left(V_{l}\right)$ e do ar $\left(V_{a}\right)$ Fonte: SILVA et. al. 2004

A variação das velocidades para o caso simulado é bastante rápida. Nos primeiros cinco centímetros do escoamento as velocidades já estão igualadas e menores do que $10 \mathrm{~m} / \mathrm{s}$.

\subsubsection{Variação do raio das gotas}

A figura 6.5, por sua vez, apresenta a variação do tamanho (raio) que as gotas sofrem, após deixarem o aspersor, em função da distância percorrida:

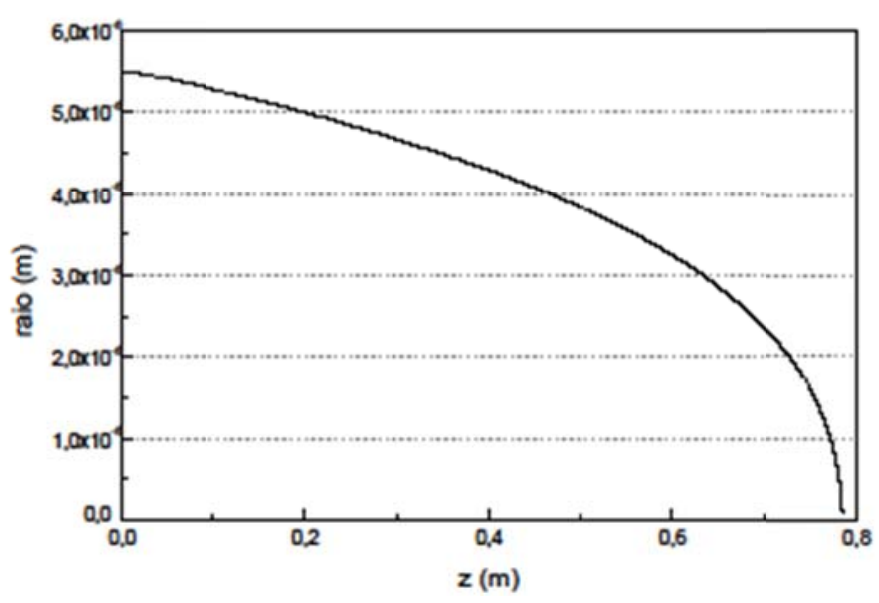

Figura 6.5 - Variação do raio das gotas Fonte: SILVA et. al. 2004

A variação do raio das gotas é diretamente proporcional ao fluxo de massa (m) e inversamente proporcional à área da gota $\left(4 \pi a^{2}\right)$. Pode-se notar que a variação do raio das gotas é mais acentuada no final do escoamento do spray. Isso ocorre porque os coeficientes de transferência convectiva de calor $(h)$ e de transferência convectiva de massa $\left(h_{m}\right)$, são 
inversamente proporcionais ao raio da gota. Assim, quanto menor o raio da gota $(a)$ maior os coeficientes de transferência convectiva de calor e massa.

\subsubsection{Vazão de entrada do líquido}

A vazão de liquido é diretamente proporcional à pressão e ao diâmetro do aspersor. A combinação de um aspersor de diâmetro maior sob pressão também maior poderia produzir gotas de mesmo diâmetro com maior vazão de líquido. SILVA et. al. (2004) testaram alguns tipos de aspersores e os resultados obtidos podem ser observados na figura 6.6, como segue:

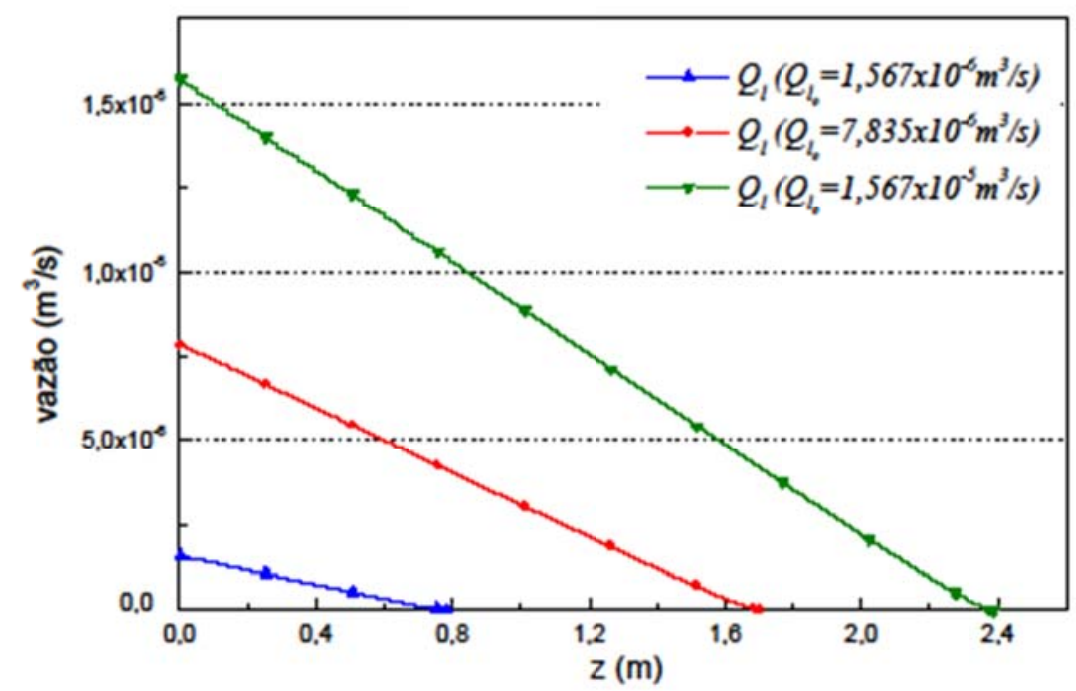

Figura 6.6 - variação da vazão de entrada do spray Fonte: SILVA et. al. 2004

O comportamento da vazão do spray é linear em relação a distância e o que apresenta maior vazão de líquido apresenta maior redução da temperatura do ar e consequente aumento da umidade do ar.

Com relação a umidade relativa obtida por estes aspersores, os resultados estão indicados na figura 6.7: 


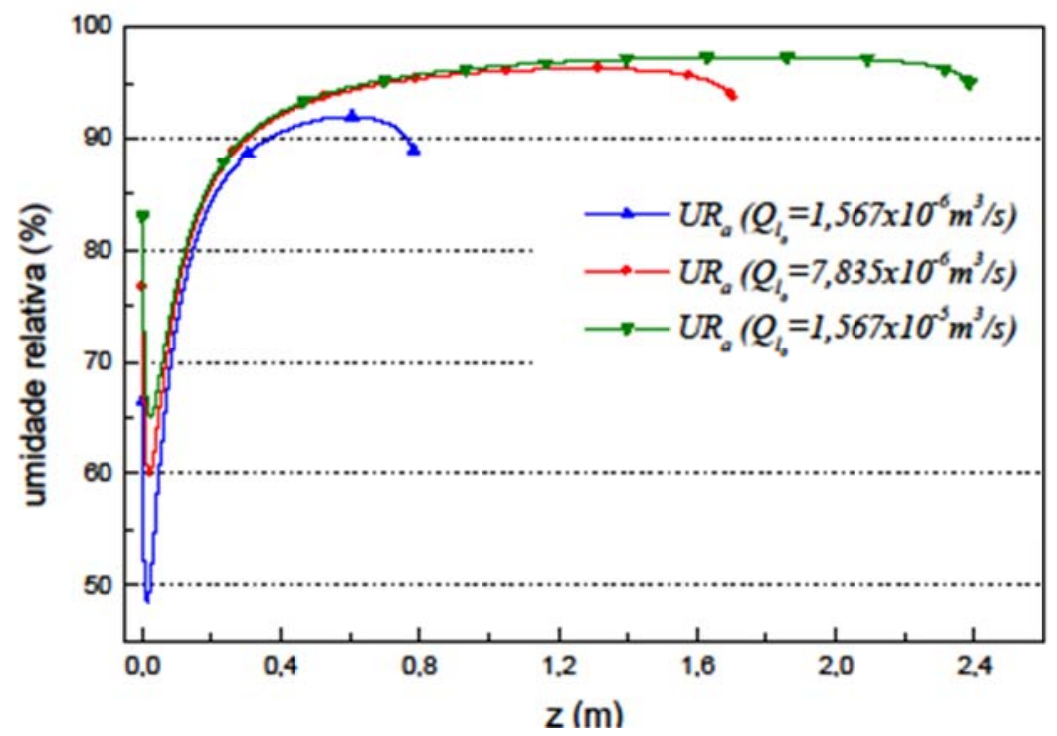

Figura 6.7 - Variação da umidade relativa em função da vazão Fonte: SILVA et. al. 2004

Os casos simulados demonstram a complexidade do funcionamento de um sistema de resfriamento evaporativo por micro aspersão de água. Inúmeras combinações de variáveis e valores, que abrangem desde tamanho das gotas até o tempo de acionamento do sistema, resultam igualmente em grandes possibilidades de adequação ou inadequação do sistema ao contexto de um ambiente climatizado.

Algumas dessas combinações de variáveis, as quais não se consegue estabelecer uma interferência de controle, atuam de forma significativa no contexto do ambiente climatizado por resfriamento evaporativo. A altitude, por exemplo, é de grande importância no desempenho de um sistema de resfriamento evaporativo. Sob menor pressão há um incremento do fluxo de massa $(\dot{\mathrm{m}})$, devido ao aumento da umidade absoluta $\left(W_{S}\right)$ e de difusividade $\left(D_{A B}\right)$, além uma redução da densidade do ar $\left(\rho_{a}\right)$.

Uma segunda combinação são as condições externas. Pode-se observar que, em função das condições externas e da carga térmica da edificação, umidades relativas acima de determinados valores faz com que o sistema de resfriamento evaporativo pode ou não conseguir atender às exigências de conforto.

Para minimizar os efeitos do aumento da umidade externa no desempenho do sistema, deveríamos incrementar as trocas de ar no ambiente interno. Desta forma, o projeto de instalação proposto deveria envolver, também o dimensionamento do sistema de ventilação, de modo a se obter a combinação mais adequada para manter o conforto estimado. 
As trocas de ar vão influenciar diretamente a penetração do spray e, consequentemente, os riscos de umedecer objetos próximos aos aspersores.

Fechar a edificação para evitar o ingresso de ar quente e seco do exterior foi uma estratégia utilizada pela indústria têxtil no início do século XIX, para manter a umidade interna das fábricas. No entanto, para ocorrer a evaporação e o resfriamento é necessário a renovação do ar que, naquela época, foi negligenciada. Disso resultou que o ambiente se tornava quente e saturado, o que era extremamente desconfortável aos operários. A solução veio com a utilização da ventilação de forma mais criteriosa.

A partir das colocações e observações efetuadas, cabe sintetizar as variáveis do comportamento estudas e resumi-las assim:

1) Quanto ao processo evaporativo:

- Quanto maior a velocidade de entrada das gotas, mais rápida é a sua evaporação.

- O raio das gotas é uma das variáveis que mais interfere no desempenho do spray. Para uma mesma vazão de líquido, quanto menor o raio das gotas melhor o desempenho.

- O aumento da vazão de líquido acentua a redução da temperatura do ar tratado e aumenta a penetração do spray.

- Quanto mais quente e seco for o ar induzido, melhor o desempenho do spray na redução da temperatura do ar tratado.

2) Quanto aos resultados esperados

- A ventilação é essencial no processo de resfriamento evaporativo e o dimensionamento do número de trocas de ar pode determinar o alcance dos parâmetros estabelecidos para o conforto térmico.

- Quanto maior a altitude melhor o desempenho do sistema de resfriamento evaporativo.

- As condições do ar exterior e as cargas térmicas definem o temperatura e umidades alcançadas com o sistema de resfriamento. 
- O padrão de acionamento define o refinamento do modelo de integração do sistema com a edificação.

\subsection{Vazão e Evaporação}

Ao observarmos a síntese do comportamento das variáveis do sistema de resfriamento evaporativo podemos verificar que todas estão relacionadas à vazão ou evaporação das gotas micro aspergidas. O spray é gerado a partir de um micro aspersor (vide tabela 4.1) que produz um determinado tamanho de gota para uma determinada pressão de operação e vazão correspondente, ou seja, não se pode alterar a pressão de trabalho sem que isso reflita na vazão do spray e no tamanho (diâmetro) das gotas geradas.

Em função disso, por maior que seja o nível de automação relacionado a operação do sistema instalado, não teríamos dificuldades em obter leituras precisas de variáveis e relações e cálculos absolutamente confiáveis do processo de resfriamento. Entretanto, por mais avançado, também, que seja o software de controle, o único comando que se pode estabelecer no sistema é $O N / O F F$.

Como dito anteriormente, a nível operacional, a única ação controlada do sistema é o tempo de operação do equipamento de pressurização (bomba de pressão), ou seja, o tempo ligado e desligado, como forma de regular a quantidade de água micro aspergida no ambiente. Essa condição operacional é o principal fator limitante da aplicação dos sistemas de resfriamento evaporativo. Cabe lembrar aqui que sempre podemos recorrer a insuflamento e exaustão forçadas como forma de controlar as trocas de ar no ambiente, desde que o acréscimo de consumo energético e as condições da edificação assim permita.

As limitações da aplicabilidade dos sistemas de resfriamento evaporativo em alta pressão estão, na sua maioria, relacionadas as variações dos parâmetros ambientais (variáveis ambientais) e as interferências causadas pela própria edificação (variáveis de projeto). $\mathrm{O}$ objetivo deste trabalho é estudar uma possibilidade de se estabelecer um maior controle sobre o processo de atomização, ou seja, na formação da gota e na vazão de saída do spray a fím de que seja possível a alteração desses parâmetros durante o funcionamento do sistema, interferindo, conforme a necessidade, no desempenho do processo de resfriamento evaporativo e, consequentemente, reduzindo as limitações de instalação.

Criar e manter ambientes industriais termicamente adequados a esses processos de produção no sentido de minimizar as interferências que as condições ambientais exercem em 
seus processos, no consumo energético e nos custos de produção, ẽ uma necessidade. A indução de ar provocado pela velocidade das gotas na saída do spray se configura como a função de maior importância a ser observada e, claro, provocado a realização de alguns experimentos.

O primeiro experimento realizado tinha o objetivo de avaliar a vazão do ar induzido pelas gotas geradas. Esse experimento, executado durante uma instalação, foi de confinar um aspersor dentro de um tubo de PVC afim de que a transferência da quantidade de movimento das gotas para o ar fosse, também, confinada dentro do tubo de PVC. O diagrama desse experimento está representado na figura 6.8:

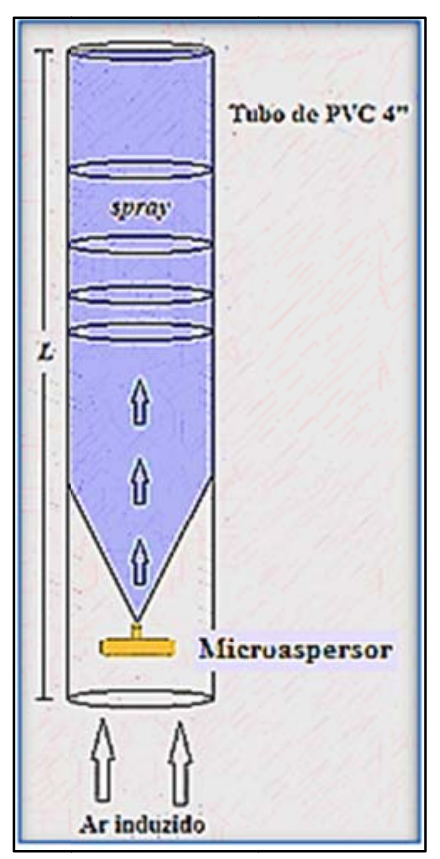

Figura 6.8 - diagrama do experimento de confinamento do spray e do ar induzido

Desse experimento as seguintes observações são colocadas:

1) Boa parte da água micro aspergida choca com a parede interna do tubo de PVC, condensando e não atingindo a saída do tubo. As gotas que alcançavam a saída eram gotas de menor diâmetro e se evaporavam quase que instantaneamente após contato com o ar externo.

2) A distância " $L$ " que o jato percorre no interior do tubo determinava o tamanho e a quantidade das gotas que atingiam a saída. 
3) Ao se impedir a entrada do ar induzido, praticamente nenhuma gota atingia a saída do tudo.

A fim de facilitar a observação desses fenômenos, a configuração do experimento foi alterada para que a entrada do ar induzido e a saída do condensado não ocupassem a mesma abertura inferior do tudo PVC. A nova configuração do experimento ficou montada conforme figura 6.9, abaixo:
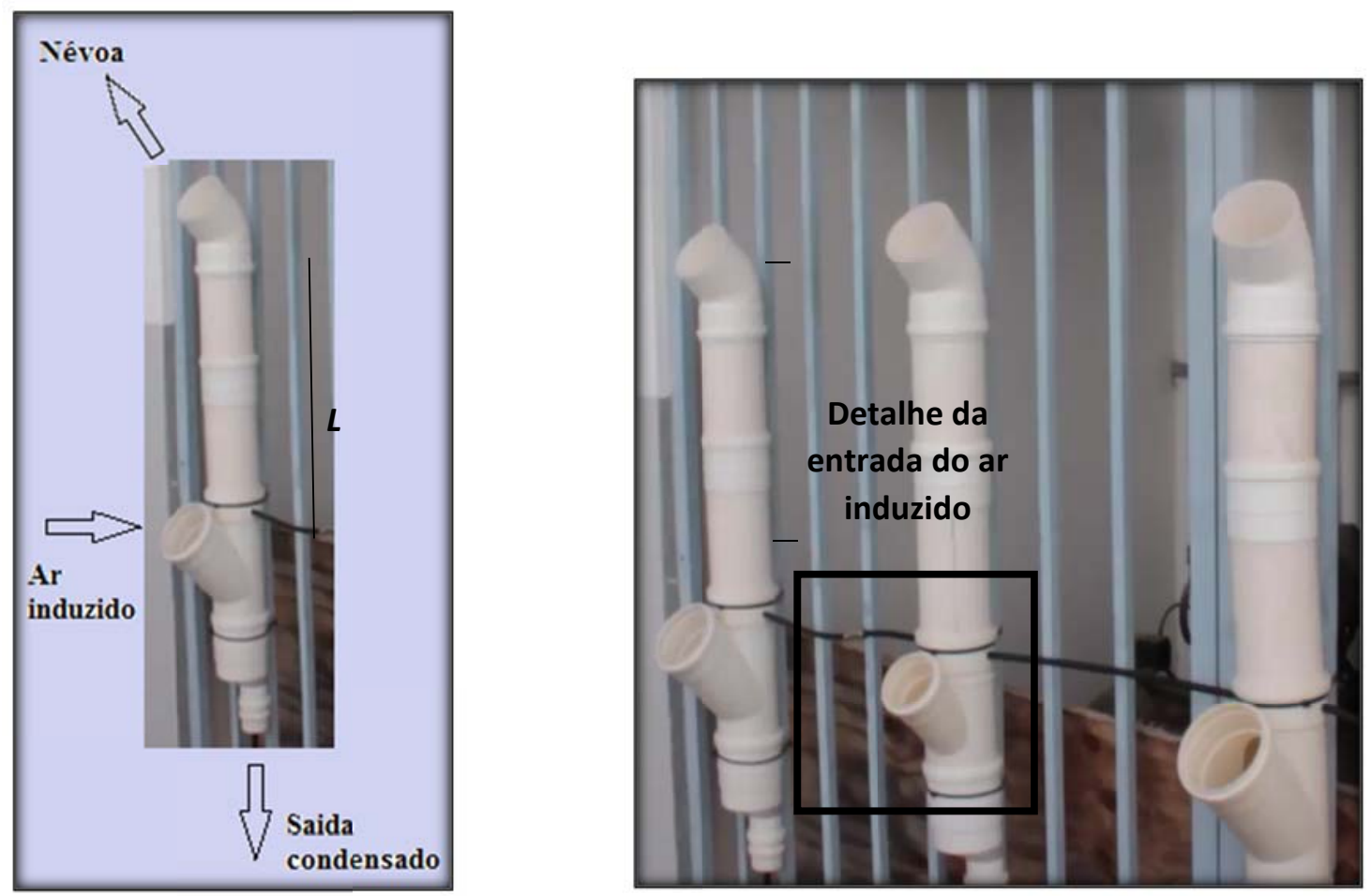

Figura 6.9 - Experimento com a configuração alterada com a saída de condensado separada do ar induzido

Fonte: Instalação executada pelo autor - experimento com o ar induzido

O experimento foi montado avaliando duas possibilidades, com um e dois aspersores no mesmo tubo, conforme figura 6.10, a seguir:
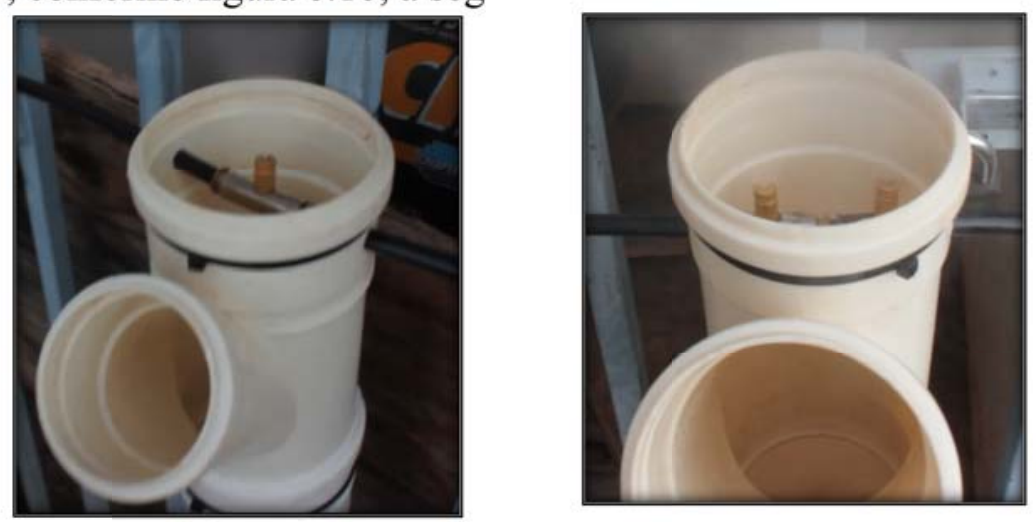

Figura 6.10 - Detalhe da entrada do ar induzido e a posição do aspersor no tubo (montados com 1 e 2 aspersores)

Fonte: Instalação executada pelo autor - experimento com o ar induzido 
O experimento apresentou resultados que colocam a transferência da quantidade de movimento das gotas para o ar como fundamento dessa aplicação. Os entendimentos trazidos por esse modelo de aplicação podem ser assim descritos:

- As gotas que não se condensam na parede do tubo, atingindo a saída tem seus diâmetros definidos pelo comprimento " $L$ " e são, a princípio, inversamente proporcionais, ou seja, quanto maior o comprimento " $L$ " menor o diâmetro das gotas que atingem a saída.

- O comprimento do tubo define, ainda, um padrão de tamanho de gotas, ou seja, as gotas micro aspergidas pelo tubo teriam seus diâmetros bastante próximos, $\mathrm{o}$ que é conveniente para a taxa de evaporação.

- Ao se bloquear a entrada do ar induzido pela transferência da quantidade de movimento das gotas para o ar, toda água micro aspergida, independentemente de um ou dois aspersores no tubo se condensa nas paredes e, praticamente, nenhuma gota atinge a saída do tubo. A dedução lógica é que a retirada do ar induzido faz com que as gotas se choquem entre elas e, por sua vez, com a parede do tudo, saindo pelo dreno (saída do condensado).

- A quantidade de água (ou gotas) que sai pelo tubo é proporcional a quantidade de ar induzido que entra pela abertura. Isto significa que, ao limitarmos a quantidade de ar no bocal de entrada de ar induzido, estamos limitando e regulando a vazão de água micro aspergida.

- A penetração do spray no ambiente é função direta da velocidade de água micro aspergida. Agora, utilizando esse modelo de aplicação, temos o controle de vazão estabelecida e, por consequência, a penetração do spray, também, controlada. 


\subsection{Conclusão}

Até então, o único controle que se poderia estabelecer na operação dos sistemas de climatização por resfriamento evaporativo em alta pressão, era diretamente no módulo de pressão (bomba de aspersão), ligando e desligando o motor elétrico do equipamento ou colocando em regime intermitente (ligado e desligado) com comando efetuado pela leitura de parâmetros de tempo e/ou de umidades e temperaturas. Esse modelo de aplicação proposto abre uma nova e inédita frente de estudos para utilização desse sistema no controle de ambientes internos. Conseguimos com esse modelo controlar a vazão de aplicação do spray no ambiente, sem que seja alterada sua pressão na geração das gotas. Mais ainda, manter a alta pressão é fundamental no estabelecimento das velocidades de saída do spray e consequente indução do ar, responsável direto para o controle da vazão.

A melhoria das taxas de trocas de calor e massa do spray com o ambiente é obtida pelo incremento da área superficial do líquido aspergido o que faz do controle do processo de atomização, na formação das gotas e da vazão de saída do spray, condição de garantia da evaporação total do líquido. Esse novo modelo de aplicação veio permitir alterar esses parâmetros durante o funcionamento do sistema, interferindo, conforme a necessidade no desempenho do sistema de redução de temperatura e controle da umidade internos.

As possibilidades de exploração de desenvolvimento desse modelo são inúmeras. Novas frentes de estudos devem ser conduzidas de tal forma que se crie um modelo de aplicação explorando todas as novas variáveis que vieram com essa proposta. A modelação dessa "nova" forma de aplicação deve, a princípio, explorar e estabelecer como se relacionam os seguintes parâmetros:

- Diâmetro do tubo e número de aspersores internos;

- Comprimento do tubo e tamanho das gotas na saída;

- Dimensionamento do micro aspersor (pressão e vazão) e vazão de ar induzido;

- Controle da entrada de ar e vazão de saída do spray com a penetração das gotas no ambiente;

- Características da edificação e trocas de ar com a vazão do sistema. 
A modelagem dessa nova proposta vem com os estudos experimentais necessários a continuidade desse trabalho, agora com o objetivo mais ousado que é o de criar uma forma de dimensionamento que garanta $100 \%$ da evaporação da água micro aspergida e o controle das condições de conforto térmico em amplo espectro. 
ABNT. ASSOCIAÇÃO BRASILEIRA DE NORMAS TÉCNICAS: NB-10 - Instalações Centrais de Ar Condicionado para Conforto - Parâmetros Básicos de Projeto, 1978.

ARBEL, A.; YEKUTIELI, O. e BARAK, M. Performance of Fog System for Cooling Greenhouses. In: J. Agrc. Engng Res. 72, pp. 129 - 136, 1999.

ARBEL, A.; BARAK, M. e SHKLYAR, A. Combination of Forced Ventilation and Fogging Systems for Cooling Greenhouses. In: Biosystems Engineering, 84 (1), pp. 45 - 55, 2003.

ASHRAE. Thermal Environmental Conditions for Human Occupancy. In: ASHRAE Standard (55). Atlanta, GA, 1992.

ASHRAE. Chapter 47, Evaporative Air Cooling, ASHRAE Applications Handbook, 1995. Atlanta: American Society of Heating, Refrigerating and Air-conditioning Engineers, Inc. New York, NY, 1995.

ASHRAE Psychrometrics - Theory and Practice, ASHRAE Research Project, 1995. Atlanta: American Society of Heating, Refrigerating and Air-conditioning Engineers, Inc. New York, NY, 1996.

ASHRAE. Psychrometrics. Handbook - Fundamentals, Chapter 1. 2009.

BASSILY, A. M. Effects of evaporative inlet and aftercooling on the recuperated gas turbine cycle. Applied Thermal Engineering, v. 21, n. 18, p. 1875-1890, 2001.

BECK, J. C. e WATKINS, A. P. The droplet number moments approach to spray modeling: The development of heat and mass transfer sub-models. In: International Journal of Heat and Mass Flow, 24 pp. 242 - 259, 2003.

BHATIA, B.E. Principles of Evaporative Cooling System. PDHonline Course M231. 2012. Disponível em: http://www.pdhonline.org. Acesso em 14 de jan. 2016

BASTOS, A. I. U. Avaliação do uso de resfriamento evaporativo indireto em sistemas de climatização de edificações comerciais. sites.poli.usp.br. No prelo 
BELDING, W. A.; DELMAS, M. P. F. Novel desiccant cooling system using indirect evaporative cooler, ASHRAE Transactions, vol. 103, part 1, 1997. p.841-847.

CAMARGO, J. R. Sistemas de resfriamento evaporativo e evaporativo-adsortivo aplicados ao condicionamento de ar. Tese (Doutorado em Engenharia Mecânica) Faculdade de Engenharia do Campus de Guaratinguetá, Universidade Estadual Paulista, Guaratinguetá, 2003. 140f.

CAMARGO, J. R.; GODOY Jr, E.; EBINUMA, C.D. An Evaporative and Desiccant Cooling System for Air Conditioning in Humid Climates. J. of the Braz. Soc. of Mech. Sci. \& Eng. Rio de Janeiro, Vol. XXVII, No 3, p. 243, July-September 2005.

CE-02. Desempenho térmico de edificações - Parte 3: Zoneamento Bioclimático Brasileiro e Diretrizes Construtivas para Habitações Unifamiliares de Interesse Social. CB-02 -Comitê Brasileiro de Construção Civil. CE-02: 135.07 - Comissão de Estudo de Desempenho Térmico de Edificações, 1998.

CENTER, Marine Prediction; CENTER, Hydrometeorological Prediction. National Oceanic and Atmospheric Administration (NOAA). Space Weather Alerts. http://www. swpc. noaa. gov/alerts/description. htm, 1999.

CHAlfoun, N. An Education, Research and Community Outreach Program. House energy doctor. Disponível em: http://capla.arizona.edu/hed/charts.php. Acesso em 09 de abril de 2016.

CHAPPELLS, H.; SHOVE, E. Comfort: A review of philosophies and paradigms [R/OL]. 2009.

CHEN, Q. et al. A new approach to analysis and optimization of evaporative cooling system I: Theory. Energy, v. 35, n. 6, p. 2448-2454, 2010.

CLARK, D. R. Method and apparatus for determining relative humidity. U.S. Patent n. 5,435,146, 25 jul. 1995.

CROWE, C.T.; SHARMA, M.P. e STOCK, D.E. The particle-source-in-cell (PSI-cell) model for gas-droplet flows. In: J. Fluid Eng., 99, 325-334, 1977. 
DONALD, J.; ECKMAN, M.; SIMPSON, G. Keys to getting good performance from your evaporative cooling system. The Alabama Poultry Engineering and Economics Newsletter, n. 5, 2000.

EEC - ENVIRONMENTAL ENGINEERING CONCEPTS INC. Database Design, Development, Implementation, and Utilization. In: Project Highlights, 2005.

ENGENHARIA NA AGRICULTURA, Viçosa, MG, v.13. n.4, 277-286, Out./Dez., 2005.

FAETH, G.M. Current status of droplet and liquid combustion. In: Progress in Energy and Combustion Science, No. 3, pp. 191 - 224, 1977.

FAETH, G.M. Evaporation and combustion of sprays. In: Prog. Energy Combust. Sci., Vol. 9, pp. $1-76,1983$.

FANGER, P. O. Moderate Thermal Environments Determination of the PMV and PPD Indices and Specification of the Conditions for Thermal Comfort.ISO 7730, 1984.

FERZOLA, J. F.; Análise global de um sistema de refrigeração industrial. Porto Alegre, 2010. Trabalho de conclusão do curso, Universidade Federal do Rio Grande do Sul.

FIALA, D.; LOMAS, K.J. MARTINEZ, D. e COOK, M.J. Dynamic thermal sensation in PDEC buildings. In: PLEA'99 Conference, pp. 243 - 249, 1999.

GHOSH, S. e HUNT, J.C.R. Induced air velocity within droplets driven sprays. In: Proc. R. Soc. Lond. A 444, pp. 105-127, 1994.

GIVONI, B. Performance and applicability of passive and low-energy cooling systems. In: Energy and Buildings, Vol. 17, pp.177-179, 1991.

GIVONI, B. Comfort, climate analysis and building design guidelines. In: Energy and Buildings, Vol. 18, pp.11-23, 1992.

GIVONI, B. Passive and Low Energy Cooling of Buildings. Van Nostrand Reinhold. New York, 1994.

GRANT, R. P. e MIDDlEMAN, S. Newtonian Jet Stability. In: AIChE J., Vol. 12, No. 4, pp. 669-678, 1966. 
GUIMARÃES, E.T. A New Approach to Turbine Inlet Air Cooling, Turbine Inlet Cooling System, Rio de Janeiro, Brasil, 2000.

GUO, Z. Y.; ZHU, H. Y. \& LIANG, X. G. Entransy-A physical quantity describing heat transfer ability. Int J Heat Mass Transfer, Vol. 50, pp. 2545, 2007.

ISO STANDARD: Moderate thermal environments- Determination of the PMV and PPD indices and specification of the conditions for thermal comfort: ISO7730.

JAIN, D. e TIWARI, G. N. Modeling and optimal design of evaporative cooling system in controlled environment greenhouse. In: Energy Conversion and Management, 43, pp. 2235 $-2250,2002$

KACHHWAHA, S. S.; DHAR, P. L.; KALE, S. R. Experimental studies and numerical simulation of evaporative cooling of air with a water spray - I. Horizontal parallel flow. In: Int. J. Heat Mass Transfer. Vol. 41. No. 2, pp. 447 - 464, 1998.

LAMBERTS. R.; DUTRA, L.; PEREIRA, F. O. R. Eficiência energética na arquitetura. São Paulo, PW, 1997.

LECHNER, Norbert. Heating, cooling, lighting: sustainable design methods for architects. John wiley \& sons, 2000.

LEE, S.Y. e TANKIN, R.S. Study of liquid spray (water) in a non-condensable environment (air). In: Int. J. Heat Mass Transfer. Vol. 27. No. 3, pp. 351 - 361, 1984.

LEFEBVRE, A.H. Atomization and Sprays. Hemisphere Publishing Corporation. 421p. 1989.

LOMAS, K. J.; FIALA, D.; COOK, M. J. e CROPPER, P. C. Building bioclimatic charts for non-domestic buildings and passive downdraught evaporative cooling. In: Building and Environment, 39, pp. 661-676, 2004.

MEDEIROS, S. R. de; RIBEIRO, C. B. Abate e qualidade da carne; outros aspectos relacionados à qualidade da carcaça. Disponível em: < http://www.cnpgc.embrapa.br $>$. Acesso em: 01 de março de 2016.

MIESSE, C. C. Correlation of Experimental Data on the Disintegration of Liquid Jets. In: Ind. Eng. Chem., Vol. 47, No. 9, pp. 1690-1701, 1955. 
MURAKAMI, D.; KATO, S. NAGANO, S. TANAKA, Y. Diffusion characteristics of airborne particles with gravitational settling in a convection-dominant indoor flow field. In: ASHRAE Transactions 1992, Vol. 98, Pt.1, pp. 82 - 97, 1992.

NICOL, F. Standards for thermal comfort: indoor air temperature standards for the 21st century. Taylor \& Francis, 1995.

OLANDER, L. Equations and formulas for air and air contaminants. National Institute of Occupational Health, Report 14, 1994.

ONOFRE, M. J. C. Humidificación Adiabática; MULTIDISCIPLINARIO, Laboratório Experimental; No. 11, 1996.

PALMER, J.D. Evaporative cooling design guidelines manual. New Mexico Energy Minerals and Natural Resources Department, Energy Conservation and Management Division, New Mexico, 2002. 99p.

PERRY, R. H., GREEN, D. W. \& MALONEY, J. O. Perry's chemical engineers' handbook. Seventh Edition. McGraw-Hill, New York. 1998.

PIRES, M. de F. A.; CAMPOS, A. T. Índice de temperatura e umidade; Sinais de estresse calórico; Como medir o estresse calórico; Como amenizar o estresse calórico adotando medidas de manejo ambiental. Disponível em: < http:/www.cnpgl.embrapa.br>. Acesso em: 01 de março de 2016.

PROJETEEE, Torre de resfriamento evaporativo de fluxo descendente. Disponível em $<$ http://projeteee.ufsc.br> Acesso em: 04 de jan. 2016.

ROAF, S.; HANCOCK, M. Energy efficient building. 1992.

RORIZ, M. Potencial de uso da refrigeração evaporativa no estado de São Paulo. In: NUTAU’ 2000 - Tecnologia e desenvolvimento. São Paulo, 2000.

SAZHIN, S. S.; CRUA, C.; KENNAIRD, D. e HEIKAL, M.R. The initial stage of fuel spray penetration. In: Fuel, 82, 875 - 885, 2003.

SAZHIN, S. S.; CRUA, C.; KENNAIRD, D. e HEIKAL, M.R. The initial stage of fuel spray penetration. In: Fuel, 82, 875 - 885, 2003. 
SHARMA, N. Y., DATTA, A. e SOM, S.K. Influence of spray and operating parameters on penetration of vaporizing fuel droplets in a gas turbine combustor. In: Applied Thermal Engineering 21, pp. 1755-1768, 2001.

SILVA, A. C. S. B. et al. Simulação de resfriamento evaporativo por microaspersão d'água. 2004.

SINGH, R. P.; HELDMAN, D. R. Introduction to food engineering. Third edition. Academic Press, San Diego, 2001.

SIRIGNANO, W. A. Fluid dynamics and transport of droplets and sprays. Cambridge University Press, Cambridge, UK, 1999.

SOMMERFELD, M. e QIU, H. H. Experimental studies of spray evaporation in turbulent flow. In: Int. J. of Heat and Fluid Flow, 19, pp. 10 - 22, 1998.

STANDARD, ASHRAE. Standard 55-2013. Thermal environmental conditions for human occupancy. ANSI/ASHRAE. Atlanta, USA, 2013.

STANDARD, ASHRAE. Standard 55-1992. Thermal environmental conditions for human occupancy, ANSI/ASHRAE. Atlanta, USA, 1992.

STOECKER, W.F. e JONES, J.W. Refrigeração e ar condicionado. McGraw-Hill, São Paulo, 481 p., 1985.

TRANE. Trane Air Conditioning Manual. The Trane Company, La Crosse, Wisconsin, 456 p. 1978.

TURNS, S. R. An Introduction to Combustion - Concepts and Applications. McGrawHill, Inc. 1996.

VICHI, F. M.; MANSOR, M. A. T. C.; Energia, meio ambiente e economia: o Brasil no contexto mundial. Química Nova, São Paulo, p.757-767, abr/2009.

WATT, J. R. e BROWN, W.K. Evaporative Air Conditioning Handbook. 3rd edition. Lilburn, 1997.

ZBICINSKI, I. Development and experimental verification of momentum, heat and mass transfer model in spray drying. In: The Chemical Engineering Jounal, 58, 123 - 133, 1995. 
ZHENQIAN, C.; MINCHENG, S. Indirect evaporative cooling and desiccant dehunidifying using advanced heat pipe heat exchangers. In: Air Conditioning in High Buildings'2000, IIF/CAR, 24/27 oct 2000, Shangai, 2000. p.318-321. 